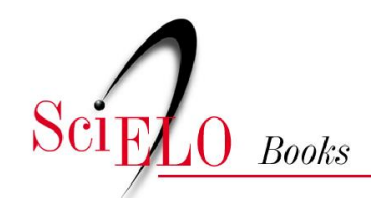

\title{
Música popular e adjacências...
}

\author{
Paulo Costa Lima
}

LIMA, PC. Música popular e adjacências... [online]. Salvador: EDUFBA, 2010, 152p. ISBN 978-85-

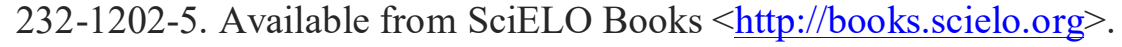

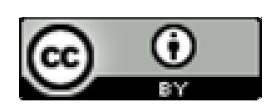

All the contents of this work, except where otherwise noted, is licensed under a Creative Commons Attribution $\underline{4.0 \text { International license. }}$

Todo o conteúdo deste trabalho, exceto quando houver ressalva, é publicado sob a licença Creative Commons Atribição 4.0.

Todo el contenido de esta obra, excepto donde se indique lo contrario, está bajo licencia de la licencia $\underline{\text { Creative }}$ Commons Reconocimento 4.0. 
Música Popular e Adjacências... 


\section{UNIVERSIDADE FEDERAL DA BAHIA}

REITORA

Dora Leal Rosa

VICE-REITOR

Rogério Bastos Leal

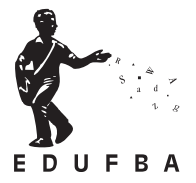

EDITORA DA UNIVERSIDADE FEDERAL DA BAHIA

DIRETORA

Flávia Goullart Mota Garcia Rosa

CONSELHO EDITORIAL

TITULARES

Angelo Szaniecki Perret Serpa

Caiuby Álves da Costa

Charbel Niño El Hani

Dante Eustachio Lucchesi Ramacciotti

José Teixeira Cavalcante Filho

Alberto Brum Novaes

SUPLENTES

Evelina de Carvalho Sá Hoisel

Cleise Furtado Mendes

Maria Vidal de Negreiros Camargo 
Paulo Costa Lima

\title{
Música Popular e Adjacências...
}

\author{
EDUFBA
}

Salvador, 2010 
(C) 2010 by Paulo Costa Lima

Direitos para esta edição cedidos à Edufba

Feito o depósito legal.

CAPA E PROJETO GRÁFICO

Amanda S. Silva

REVISÃO

Eduardo Ross

Sistemas de Bibliotecas - UFBA

Lima, Paulo Costa.

Música popular e adjacências... / Paulo Costa Lima. - Salvador : EDUFBA, 2010.

$152 \mathrm{p}$.

ISBN 978-85-232-0721-2

1. Música popular - Brasil - Crônicas. 2. Música popular - Crônicas.

3. Crônicas brasileiras. 4. Ensaios brasileiros. I.Título.

CDD - 869.98

Editora filiada à
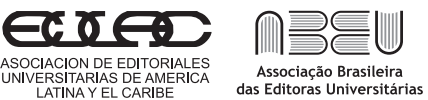

Editora da UFBA

Rua Barão de Jeremoabo, s/n - Campus de Ondina

40170-115 - Salvador - BA

Tel: $+55713283-6164$

Fax: $+55713283-6160$

www.edufba.ufba.br edufba@ufba.br 


\section{Sumário}

$\begin{array}{ll}\text { Apresentação } & 7\end{array}$

O resto é mar: o tom de Jobim 9

Meu Caro Amigo: uma homenagem a Chico e Hime $\quad 14$

Só louco 19

Gago Apaixonado $\quad 25$

Terra $\quad 27$

Isto é bom que dói! Notas sobre popular e erudito 31

Chico, Mané e Beiçola - todos três na corriola 34

Ensaio do Trio $\quad 37$

Michael Jackson e a fabricação de si mesmo $\quad 40$

Alguém pode querer me assassinar: poder e paranoia $\quad 44$

Atirei o pau no gato $\quad 47$

A música e o striptease $\quad 50$

Farofa de tanajura $\quad 52$

França-Brasil: Allons enfants da pátria amada $\quad 55$

Caminhos da análise musical 59

Em nome de quê? $\quad 62$

A música e o espelho 65

Sobre uma montanha invisível chamada música $\quad 67$

Quem é você? Carnaval e Psicanálise $\quad 71$

De Caju em Caju... até a Cajuína 75

Acabou o papel! $\quad 79$

O Carnaval e a Infanta Mafalda $\quad 81$

Os pés no riacho: Rei como personagem cultural $\quad 84$

A música é uma causa $\quad 88$

Debaixo do barro do chão $\quad 91$

Tudo azul 94

Em busca de uma 'razão composicional' 97 
Aos Mestres com Carinho $\quad 100$

Apesar de você: a música e a ditadura 104

A hora e a vez da 'erupodiputolização'... 108

Caso de orquestra: um espirro em Mozart 111

O Brasil merece: Não venha, não! 114

Quem é o autor? 117

Cultura, doença e bloqueio amoroso $\quad 120$

Nós e a Galhofa 123

Fevereiro vem aí - sempre... 126

Música e Oxitocina 129

O que sinto pela música 132

Ai, minha mãe! 136

O diálogo entre a merda e o marfim $\quad 148$

Algumas Referências 151 


\section{Apresentação}

Composição é mais do que música? Mais do que simplesmente aquilo que se ouve? Ou bem ao contrário, a música é quem engloba tudo, inclusive as vicissitudes de sua criação? Música e Composição vão além daquilo que soa, e vibram na direção do que se pensa, do que se imagina e do que se fala. Envolvem, portanto, um mais-ouvir e até mesmo um mais-gozar, como diria Lacan. Daí nosso compromisso com o imaginário. Nossa responsabilidade com o discurso.

As crônicas e ensaios aqui apresentados surgiram dessa consciência, e especialmente da teimosia na combinação de traços e temas aparentemente opostos - leveza e incursão analítica, popular e erudito, formalismo e referencialismo, o cotidiano e o susto. Escritos a cada semana, celebrando uma abertura de diálogo com um novo público, encontram agora uma moldura em livro, algo que muito me alegra.

Em foco, de forma especial, algumas canções brasileiras, buscando identificar caminhos e processos de construção composicional - mostrando que o terreno é fértil, e menos visitado do que deveria ser, especialmente agora que a complexidade das hierarquias não mais precisa das fronteiras de ontem, e nem mesmo de fixar receitas de complexidade.

Nesse novo tempo de paradigma, a criação musical se espalha pelo mundo, e a nossa compreensão do fenômeno apenas engatinha. Longe 
de ser simples 'carnaval conciliador', esse é o novo patamar do desafio crítico, para uma visão transformadora do mundo.

Não sei o que é música popular - não vejo muito sentido em tal denominação -, mas preciso da atenção dos muitos que usam a nomenclatura, justamente para tecer esses caminhos, para identificar processos mais amplos, para brincar com os limites entre estratégias de análise da canção e da cultura.

Pensando em Jobim chego no conceito de 'tonalidade suspensa'. Em Caymmi, esbarro, por incrível que pareça, na teoria dos conjuntos como medida de sua organicidade. Em Chico, proximidade e distância estão igualmente aninhadas na sintaxe e na semântica. Noel Rosa remete a um modelo bem nosso de anarquia e criatividade, o gago realiza sua apoteose em plena ária de ópera. Poder e paranoia: toca Raul! Já repararam a proximidade extrema entre o Hino Nacional e a Marsellaise? Quem foi o autor da versão apócrifa de Jingle Bells? Caetano e a arte de flutuação melódica em direção à Terra. Michael Jackson e a tendência à auto-fabricação numa época de declínio da figura do pai simbólico...

Caro leitor: nada de piparotes. Pago-lhe com um acorde de sétima e nona com quinta aumentada na Dominante da Dominante da Dominante e Adeus. 


\section{O resto é mar o tom de Jobim}

A canção é toda cheia de onda, e o seu autor-personagem não deixa por menos. Na versão em inglês, adverte ${ }^{1}$ : Don't try to fight the rising sea (não tente lutar contra o mar que se ergue). Está aí, de próprio punho, uma declaração sobre o umbigo temático da obra, que, não por acaso, leva o nome de Wave (onda) - uma das canções brasileiras mais cantadas em todo o mundo.

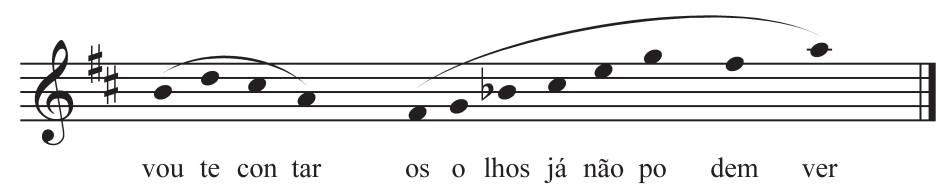

A figura acima mostra o primeiro gesto. A marolinha do 'vou te contar' e a onda inexorável, se erguendo logo após. Basta cantar esse início para perceber que, na canção, o gesto de onda é tão fundamental quanto o amor. Ou melhor, que o amor, a onda, o mar, brisa, cais, noite, estrelas, cidade, eternidade, indizível, tudo isso se mistura e se aproxima nesse verdadeiro hino... ${ }^{2}$ Pois é, essa é a palavra que me ocorre - hino. Mas que espécie de hino seria Wave? 
Não resta dúvida que é uma canção emblemática, mas como gênero é o avesso dos hinos. A distância heráldica, heroica, histórica que o hino constrói, aqui de nada serve. A canção-onda trata de proximidade, de envolvimento, e de mansinho, como a brisa que diz - 'é impossível ser feliz sozinho' (sic).

Veja, por exemplo, a marolinha do início - 'vou te contar'. Gesto mínimo de significação máxima. Cria um laço todo especial com quem ouve. Só se fala isso na intimidade de uma roda, que é também a intimidade de uma comunidade linguística - carioca, brasileira. Bem ao gosto da bossa-nova, a canção nos define a partir de uma perspectiva anti-heráldica, coloquial, como se a roda de amigos fosse o próprio País. A força do seu vínculo. E não é?

E vejam que sutileza bacana: as palavras do verso veiculam um ritmo de samba, que tem a ver com a alternância entre as consoantes $(\mathrm{t}, \mathrm{k}, \mathrm{t})$, como se aí entrasse um chocalho ou coisa parecida - aliás, do mesmo jeito que o famoso ancestral 'qual é o pente que te penteia', esse aí, já é uma verdadeira batucada.

Como técnica de composição, esse Jobim maduro nos coloca diante de um amálgama - gestos textuais e outros gestos sonoros, ideias de texto e ideias de som que se interpenetram para configurar o todo-onda que deságua sobre a gente. Tudo isso num ambiente de miniatura, onde muitas vezes a sugestão da ideia é bem mais eficaz do que sua explicitação.

Aliás, na arte de fazer letra, o não dizer é tão importante quanto o dizer - às vezes, mais. De repente prevalece a imagem. Por exemplo, quem é que não se pega contemplando o céu noturno quando a canção fala em 'estrelas que esquecemos de contar'? Ou visualizando um cais, a onda que se ergueu no mar, e até mesmo a eternidade, que obviamente é impossível de visualizar, mas a canção tenta ${ }^{3}-$ faz parte do seu charme... 
Então, voltando, os três primeiros segundos da canção ('vou te contar') trazem em si as sementes de todo o resto - algo que é um princípio de coerência do compor, e reúne: o formato de onda, a proximidade que envolve, a malemolência de seu gingado rítmico, a imbricação dos textos musical e poético, e uma harmonia que flutua (Ré Maior com sétima maior e nona), que paira suspensa - da qual trataremos logo adiante.

Existem vários exemplos na literatura de canções que transformam o mar em metáfora. Caymmi deixou pelo menos duas pérolas desse tipo - 'O Mar' e 'É doce morrer no mar'. Ambas trabalham com gestos musicais que absorvem características de onda, e cada uma apresenta soluções fascinantes. Há também canções folclóricas, como 'Ondina': IaIá olha a onda, na ponta de areia...(3)

Digo tudo isso para lembrar que Jobim não inventou a roda ou a onda como metáfora musical. Mas suas escolhas compõem um cenário diverso, todo seu. O mar de Jobim é um mar urbano, bossa-novista, cheio de matizes e de imagens, meio impressionista, lírico, zen, e claramente carioca. Não se apoia, como o de Caymmi, no olhar arquetípico de uma comunidade de pescadores.

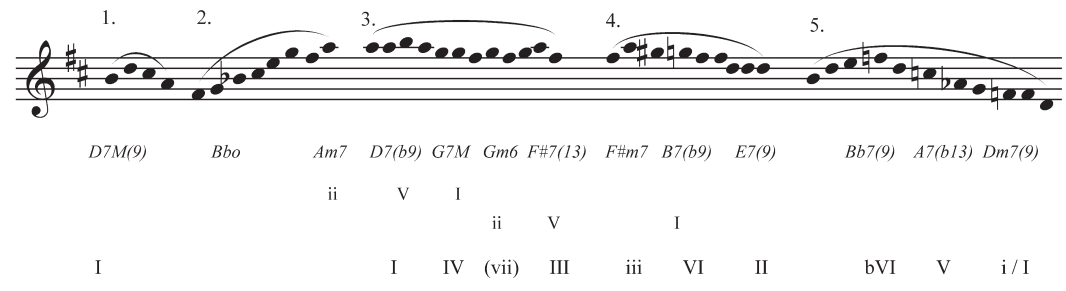

Aí está, no exemplo abaixo, uma visão do todo da onda que se fez canção: de 'vou te contar' até 'impossível ser feliz sozinho'. 
Depois da marola e da subida da onda, chegamos ao grupo (3). É um gesto que se equilibra lá em cima da onda, certamente aquelas espumas que a gente sempre vê: 'coisas que só o coração pode entender.' O grupo (4) começa o processo de descida e de focalização harmônica para o final: 'fundamental é mesmo o amor'. $\mathrm{O}$ acorde de Mi maior faz a diferença, prepara a Dominante. $\mathrm{O}$ arremate cabe ao grupo (5) e sua impressionante blue note: 'é impossível ser feliz sozinho'. A resolução final é um exemplo portentoso de mistura de modos. Já não existe maior e menor, os dois se entrecruzam. $\mathrm{O}$ acorde aumentado de Dominante (Lá) antecipa a terça do ré menor.

Por mais impressionante que seja o traçado melódico da canção, vale lembrar que toda a cor de Wave vem do trabalho harmônico. Jobim vive num mundo harmônico que já não é o da tonalidade tradicional. A musicologia cunhou um termo para técnicas semelhantes às que ele usa, e que foram desenvolvidas no final do romantismo europeu: tonalidade 'suspensa'.

O Ré maior/menor de Wave convence quando chega, sempre no final dessa sequência. Mas durante a canção parece difícil afirmar que este seja o centro tonal. $\mathrm{O}$ autor faz um monte de peripécias harmônicas ameaçando tonicalizar outros acordes - Sol e Si maior - mas logo, logo desliza em sequências harmônicas sem permitir que estes se afirmem.

Tudo temperado com muitas dissonâncias acrescentadas aos acordes, cromatismo, suspensões, acordes aumentados e por aí vai. Ao sobrepor terças aos acordes mais simples, cria-se um estado harmônico mais fluido, com muitas implicações. Essa flutuação harmônica expressiva sustenta o ciclo melódico da onda.

O gráfico acima mostra as duas sequências internas para Sol e $\mathrm{Si}$ (ii V I). E, na última linha, mostra que apesar de toda essa complexidade harmônica há uma sequência de base, que é a mais tradicional de todas - a progressão fundamental. Ou seja, sustentando toda a 
pseudo-anarquia harmônica o que temos é a tradicional rota de baixos fundamentais visualizada por Rameau em 1726.

O jogo harmônico é parte integral da beleza de Wave e de seus processos de significação. Ele matiza a relação polivalente com o amor e com o existir: estar de olhos fechados, entender o indizível, coisas lindas pra te dar, as estrelas, impossível ser feliz sozinho, a noite que nos envolve.

Reúne num mesmo anseio a intensidade de amar e a intensidade de ser - especialmente do ponto de vista de sua finitude, a sensação de perda no infinito que o amor e o mar proporcionam. Esse é o tom, esse é o hino, ou anti-hino - que não exalta, porém envolve - 'We know the wave is on its way'.

Muito mais haveria pra dizer, porém fiquemos por aqui: a riqueza do artesanato de compor canções; a possibilidade de diálogo entre visões analíticas formais e semânticas; o estilo sutil de construir pertencimento; um afastamento importante da fórmula analítica do 'amor, do sorriso e da flor', usado à exaustão para falar de bossa nova; e a curiosa proximidade entre erudito e popular. O resto é mar.

${ }^{1} \mathrm{~A}$ versão em inglês é de autoria do próprio Jobim.

${ }^{2}$ Em ingles, o autor manda fechar os olhos: 'So close your eyes, for that's a lovely way to be'.

${ }^{3}$ Essa bela canção levou Ernst Widmer a construir uma obra para piano solo de rara sofisticação, as Variações em forma de onda. 


\section{Meu Caro Amigo: uma homenagem a Chico e Hime}

O que há de tão especial nessa canção?

De um lado, o tom da delicadeza - existe algo mais carinhoso do que um "meu caro amigo"? E que vai adiante: me perdoe por favor, se não lhe faço uma visita... É uma linguagem-bálsamo que a entonação quase jocosa de Chico realça e projeta (Confira no Youtube).

De outro, o tom do desabafo, um painel de durezas elencadas em carritilha logo após “a coisa aqui tá preta”, registrando muita mutreta pra levar a situação, e nessa mesma linha: careta, pirueta, sarro, sapo, cachaça... O desenlace é inevitável: "ninguém segura esse rojão".

Quem viveu a década de 70 no Brasil sabe como foi intolerável o massacre de mídia do bordão "ninguém segura esse país" - a ditadura insistia em ser coisa nossa. A canção dá o troco, com uma dose vingativa e terapêutica de ironia e de pirraça: não é um país, e sim um rojão. $\mathrm{O}$ verso talvez tenha sido profético, basta lembrar o rojão que estourou no Rio Centro alguns anos depois.

Portanto, lá vai a canção, florescendo sobre uma polaridade cruel e meiga. Não que soe partida ou desinteira. Nada disso, desce redonda pelo ouvido até o peito, e aí está um de seus grandes feitos. Sua emoção costura uma série de valores e de posições, tudo a partir de dois princípios estruturantes: a convocação do chorinho e o discurso intimista da carta. 
Ambos elegem como objetivo maior a inclusão do ouvinte como membro da comunidade auditiva e pensante estabelecida pela canção, uma comunhão sonora. O bom ouvinte também é um dos destinatários da carta, pertence a seu mundo de sentido, com o qual se identifica, um caro amigo.

Neste manifesto simultaneamente sutil e destemperado, Chico e Francis colocam a melhor herança da música brasileira, e todos que com ela se identificam, em rota de colisão crítica com o antigo regime, que graças aos céus e a muitos espinhos e pingos de suor e sangue ávidos por uma outra realidade, foi-se. Ficou a pérola.

Mas de onde vem a força do chorinho? O chorinho foi um dos primeiros exercícios de abrasileiramento que a nossa música precisou desenvolver (a partir do final do século XIX). Recebe gestos da tradição "urbana" ocidental de polcas e xótis (originalmente vindos do mundo camponês), e os reconfigura.

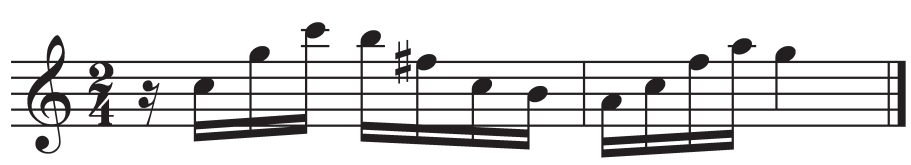

O que vemos no primeiro gesto da canção é algo claramente derivado da tradição de um Pixinguinha (confira o solo de flauta da introdução). O gesto melódico é forjado com a malícia e a malandragem desses volteios que sobem e descem. E embutidos nos volteios uma rítmica claramente influenciada pela mentalidade africana por exemplo, a acentuação "contra-hegemônica" da última semicolcheia de cada grupo - dó-si; si-lá; lá-sol - (também no pandeiro), e a formação de um jogo complexo de acentos rítmicos versus acentos métricos (3 contra 4 ), que mesmo sem querer mexe com o corpo. 
Esse gesto instrumental funciona como uma matriz que vai dar origem a todos os outros da canção, e se encaixa na voz de Chico com uma naturalidade impressionante (sem o fá\#?), como se fosse mesmo uma conversa entre amigos. (Entregue a uma soprano lírica seria um transtorno).

É claro que o gesto imita a entonação da fala carinhosa e jocosa (sobe - desce - sobe de novo - repousa), mas estica essa lógica quase ao absurdo, com subidas e descidas íngremes (oitavas e quintas) e inflexões cromáticas.

Um analista muito entusiasmado consigo mesmo diria que a proximidade (os semitons) e a distância (as oitavas e quintas) desse gesto matriz representam, no tecido musical, a tendência bipolar da obra - no caso, estar perto e longe -, ressoando a delicadeza e o desabafo já assinalados.

A negociação entre volteios rebolativos e uma harmonia típica de choro $\left(\mathrm{I}-\mathrm{vi}^{\mathrm{o}}\right.$ - ii7 - V4/2), produzem um curioso efeito sonoro nessa canção, como se fosse uma espécie de "cama de gato" - complica e tensiona até resolver como se nada tivesse acontecido.

Mas não é apenas de proximidade e distância que a "cama de gato" melódico-harmônica está falando. O que inicia como simples delicadeza entre amigos, logo na esquina vai aparecer ligeiramente modulado para cumplicidade, e já beirando o desabafo: “eu ando aflito pra fazer você ficar, a par de tudo que se passa”.

Grifo a expressão "tudo que se passa", porque ela justamente promete muito. Ela afirma que há muito a contar, mas as curvas do discurso seguinte revelam paradoxalmente que "uns dias chove, noutros dias bate sol”. Ora, que grande novidade! "Tem muito samba, muito choro e roquenrol".

Ou seja: promete-se muito e revela-se pouco. A não ser que a palavra "choro" do último verso seja tão arisca quanto o correio do qual se queixa o autor da carta. Poderia ser mais do que o gênero musical, 
na direção do horror do choro produzido pela tortura. Futebol rimando com roquenrol mais parece um espinho de alerta. $\mathrm{O}$ discurso aparentemente solto da informalidade entre amigos confunde-se com a confissão muda de um ambiente perverso, tudo isso levando a uma constatação sombria embora meio absurda: a coisa aqui tá preta.

Esses pequenos abismos do discurso encontram uma contraparte sonora nos choques melódicos apontados acima, nas subidas e descidas quase insanas, e na pouca presença da terça da tônica (o mi é guardado a sete chaves), tudo isso, porém, sempre envelopado pelo gestual harmônico e rítmico do choro. Tudo muito normal! $\mathrm{O}$ ouvinte desatento percebe apenas a beleza do choro e a letra "engraçada”. O ouvinte informado percebe o jogo sutil de denúncia embutido no humor e na ironia. O ouvinte escaldado vai descobrir como o tecido musical de sons e palavras trabalham em parceria constante.

Refaço o percurso das categorias: da delicadeza amiga para a cumplicidade - note-se que a última frase da canção reforça a ideia de um coletivo e não apenas de indivíduos (a todo pessoal, adeus...). Percebemos que a cumplicidade desemboca no desabafo e na denúncia crítica (seja da alienação esportiva e musical, ou da tortura). Depois disso surge o painel de bizarrices já comentado anteriormente. Além de ampliar o desabafo, esse painel e a ironia que o finaliza (... rojão) nos fala de teimosia, de pirraça, de engolir sapo, ou seja, de resistência, que se manifesta também através da malandragem do humor e da ironia.

Todos esses valores estão firmemente plantados no solo da canção. Mas eles giram como se fossem um móbile, embalados por algo que os transcende, e que garante a redondeza do discurso: a sedução de pertencimento que envolve o ouvinte cúmplice. Daí para as "diretas já" foi quase um pulo.

Codetta: Muito ainda haveria a dizer sobre a trama musical da peça. Por exemplo, o jogo sutil que se estabelece entre os saltos e o 
cromatismo (a proximidade e a distância). Fica o exemplo musical abaixo como aperitivo dessas análises musicais: trata-se da linha melódica da introdução, e os pequenos círculos colocados acima das notas mostram que, apesar do volteio ascendente e descendente, há uma lógica cromática subreptícia dando unidade ao tecido, tal como o segundo pentagrama registra, uma descida de oitava.

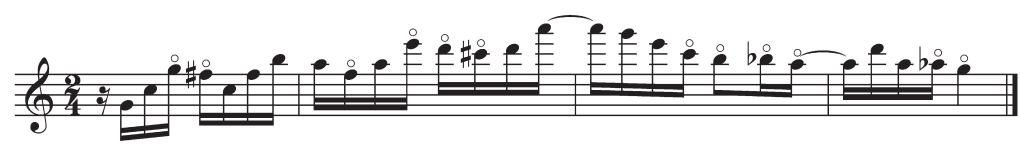

Observe a linha descendente marcada pelos pequenos círculos sobre as notas 


\section{Só louco}

Sólouco / Amou como eu amei / Sólouco / Quis o bem que eu quis Oh, insensato coração / Por que me fizeste sofrer? I Porque de amor para entender / É preciso amar / Porque / Só louco... Dorival Caymmi

O que há nesta canção de Caymmi que a faz tão marcante, tão pungente, tão dengosa? Composta lá atrás, em 1955, como 'samba-canção', ganha performances marcantes com Nana, Gal e com o próprio Caymmi, e certamente anuncia o jeitão/jeitinho da bossa nova.

Constroi no coração-ouvido da gente uma certa sensação suspensiva. A gente fica suspenso junto com a música, pairando no espaço da canção, no espaço desse monólogo onde não há referência direta ao objeto amado - 'quis o bem que eu quis' e não 'quis o bem que eu te quis' como às vezes ouvimos por aí -, pairando, em suma, na turbulência estática da fricção entre o reconhecimento da loucura do amor (sua insensatez) e ao mesmo tempo de sua inevitabilidade ('é preciso amar').

Esse jeito e esse clima da canção são ao mesmo tempo ferramentas importantes de sua arquitetura musical. Nesta singela homenagem aos 94 anos do mestre - 30 de abril - sendo ele, aliás, Doutor Honoris Causa pela Universidade Federal da Bahia desde 1984, me admiro mais uma vez e me enrosco em sua intrincada técnica com- 
posicional de construção de uma complexidade simples - como se estivesse apenas deitado numa rede bebendo água de côco.

Ex. 1:

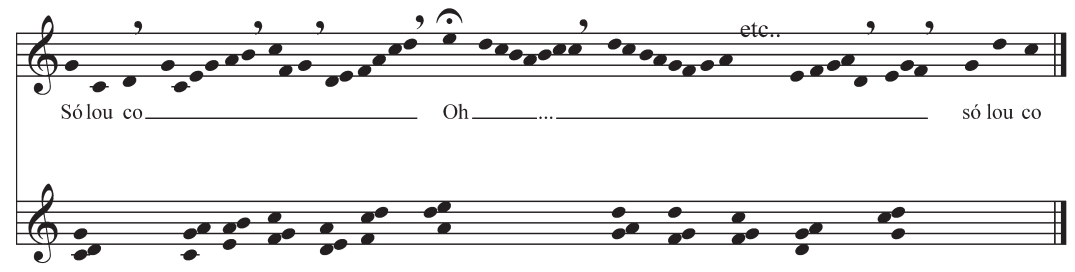

Este exemplo mostra o motivo característico da peça, que aparece quatro vezes de forma explícita, sempre composto de uma quinta justa (sol-dó) - que é o intervalo que a gente ouve logo no começo da peça em seu mergulho inicial -, sendo seguido por uma segunda maior (dó-ré), que faz um ligeiro equilíbrio de compensação, subindo (aliás, uma antiga regra de contraponto, os saltos melódicos devem ser compensados).

Esse gesto inicial de mergulho reconhece a loucura própria, 'só louco', e dá o tom expressivo da canção. Apesar do clima dissonante que a harmonia confere à canção, vale notar que a melodia utiliza apenas as 7 notas da escala diatônica maior. As 53 notas da canção são um arranjo de repetições dessas sete notas. É justamente na originalidade e simplicidade desse desenho e dessa construção que reside o gênio de Caymmi. Não dá para trocar uma nota sem perder qualidade.

O motivo característico da canção - quinta justa e segunda maior - organiza todo o discurso musical, mesmo quando não aparece de forma explícita. Ele é o responsável pela sensação suspensiva das sonoridades da canção, a segunda faz um certo bloqueio das terças, que dariam estabilidade aos acordes assim formados, tornando palpável, digo, audível, o estado de espírito desse eu lírico caymmi- 
niano, que tanto sofre como goza com o reconhecimento de sua própria condição.

Não importa se o compositor armou intencionalmente esse plano estrutural em detalhe ou se foi guiado pelo seu ouvido privilegiado. No exemplo abaixo, dois importantes gestos da peça são 'traduzidos' em termos da presença dos motivos de quinta e segunda. O primeiro deles ('a'), em termos harmônicos aparece como um acorde de sétima maior, mas vemos que o acorde também pode ser apresentado como dois motivos básicos (em 'b’). O mesmo vale para o segundo gesto.

Ex. 2

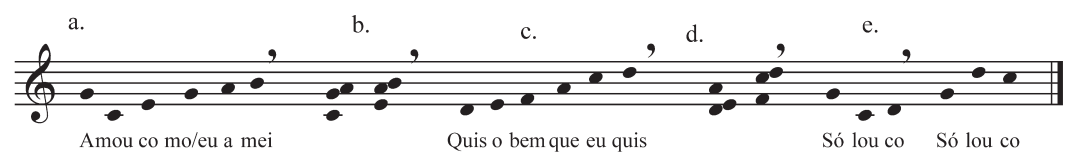

$\mathrm{Na}$ verdade, todos os gestos da canção podem ser remetidos a esse tipo de análise, mostrando a força da construção melódica em Caymmi.

Curiosamente, a única vez que o gesto básico aparece sem o texto característico ('só louco') é quase no final, em 'é preciso amar', a meu ver o outro umbigo temático da canção, a inevitabilidade. A última aparição do gesto coloca-o de forma invertida (quinta ascendente e segunda descendente, um outro recurso do contraponto), preparando o terreno para retornar ao mergulho inicial.

Ainda no exemplo acima, mostramos a simetria entre o gesto inicial e o gesto final (veja em 'e'). Esse é basicamente o âmbito da melodia, organizado por essas duas quintas partindo da nota sol, uma descendente, outra ascendente. 
Em termos de dinâmica energética da melodia, a canção começa atingindo o fundo do poço, dó, sua nota mais grave, e vai ascendendo de forma intensa e progressiva através dos versos 'amou como eu amei' e 'quis o bem que eu quis'. A melodia sobe, mas utiliza as quintas descendentes do 'só louco’ como estratégia de aumentar a tensão da subida.

Atinge um clímax ao final do verso 'quis o bem que eu quis', mas logo o substitui por outro mais intenso ainda, marcado pela interjeição 'Oh', nota mais aguda da canção. (Caymmi canta 'Oh', e Gal canta 'Ah, insensato coração!').

Daí em diante a melodia desce, reconhecendo que o coração é insensato e faz sofrer. Em suma: uma gangorra que começa lá de baixo e vai subindo até que a percepção da insensatez exige uma outra direção. $\mathrm{O}$ desenho energético da melodia reflete a mesma dualidade e gangorra entre amor/loucura e inevitabilidade/desejo. Algo que, aliás, também está anunciado no próprio motivo.

O último gráfico analítico apresenta todos os motivos de $5^{\text {a }}$ e $2^{\text {a }}$ gerados pela melodia (pentagrama inferior), mostrando que são a totalidade das quintas justas disponíveis na escala maior (a tonalidade de Dó foi escolhida para tornar mais fácil a compreensão das ideias apresentadas).

\section{Ex. 3}

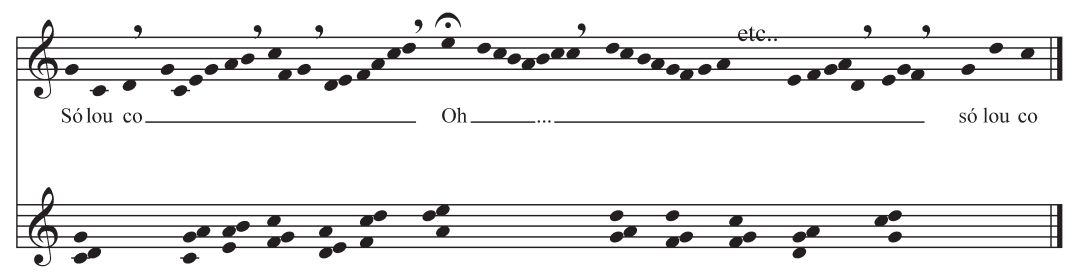

Parabéns, Mestre: 94 anos de vida! 


\section{Gago Apaixonado ${ }^{1}$}

Devo, não nego, uma crônica dedicada a Noel Rosa. Sua presença constante no cenário da música popular reafirma uma condição ímpar. A trajetória de vida não fica atrás: produziu mais de duas centenas de canções num período de sete anos, morrendo antes de completar 27 (1910-1937) - um verdadeiro vulcão. Chico Buarque reconhece que vem de sua lavra uma primeira formatação da canção popular no Brasil.

No entanto, pensar em Noel como patriarca fundador é um tanto estranho, porque ele constroi um personagem tão malemolente, irônico, gozador, anárquico - dizem que gostava de escrever versões pornográficas do Hino Nacional - que espécie de pai seria?

É claro que no Brasil a figura do pai anárquico ocupa um lugar importante no imaginário ${ }^{2}$. A falta de coesão social resultou num grande vazio de força simbólica unificadora - fomos colônia por vários séculos, e reunimos num mesmo território gente de culturas muito distintas. Xangô e Descartes nem sempre se entendem! Então, muitas vezes a liderança precisou ser exercida ao contrário, ao arrepio da sisudez e dos 'bons costumes'. No contrapelo dos limites.

É o que anuncia há mais de trezentos anos a figura de Gregório de Mattos, em sua recusa de ser porta-voz da oficialidade cultural, religiosa ou política. Traços semelhantes reaparecem em personagens e situações diversas, a exemplo de Vadinho de Dona Flor, Macunaíma 
(herói sem caráter), ou na centralidade do carnaval (festa de alegria e de anarquia), e ainda na figura do malandro.

Ora, Noel está muito ligado ao mundo da boemia e da malandragem carioca do início do século XX. E exerceu sim, diversas vezes, o papel de reverberação de contra-discursos. Um dos mais densos e candentes é o que segue:

Quanto a você / Da aristocracia / Que tem dinheiro / Mas não compra alegria

Há de viver eternamente / Sendo escravo dessa gente / Que cultiva hipocrisia

Gosto de entender a canção 'Gago Apaixonado', uma de suas criações mais interessantes, como parte desse cenário. Imperdível conferir a gravação original, feita em 1931. Quase 80 anos depois e nada chega perto do frescor de sua originalidade - é samba, chorinho, modinha lírica, e não dispensa trejeitos de New Orleans, tudo no melhor estilo. Mas, sobretudo, lá está a voz e a presença irradiante de Noel.

A inteligência composicional da canção coloca em primeiro plano a situação hilária de um gago, extravasando sua decepção amorosa ${ }^{3}$, e olha que os gagos geralmente cantam sem tropeçar. Mas há outras leituras relevantes.

Trata-se de um gago paradigmático. Quem é que alguma vez não se engasgou com a paixão? A paixão faz engasgar, gaguejar, praguejar - e eis que o nosso personagem acaba afirmando que sua 'amada' vai ficar corcunda. Nesse sentido, rir do gago é rir da própria condição humana.

Um detalhe importante: a amada não recebe nome. A canção mudaria de perfil se fosse dirigida a uma mulher específica (Rosa, Marina, Rita...), como é tão comum no repertório romântico. Noel deixa o objeto da paixão no seu nível mínimo de personalização: mu-mu-mulher. Prevalece o lado passional, do qual a gagueira faz parte.

A série de rimas que acompanha esse processo é bastante sugestiva: estrago / gago / afago. A palavra 'estrago' é um capítulo em si 
mesmo ${ }^{4}$. O gago fica espremido entre o estrago e o afago. Não espanta que sua voz falhe. Ouve-se na gravação que Noel dá uma entonação toda especial à palavra afago, quase um arrepio, fazendo ainda por cima uma pequena cesura.

Outras séries de sonoridades significativas ampliam o processo. Na série 'crueldade/da saudade/que maldade', a repetição gaguejante acentua o ridículo e quase intoxica. Em outra direção surgem sonoridades mais pesadas, quase grosseiras (o estrago está feito): 'moribundo/vagabundo' até 'tu vais ficar corcunda'. Tudo isso torna a palavra 'afago' a única recordação doce (embora chorosa) de todo o episódio.

A segunda direção de leitura pode ser vislumbrada a partir de um insight inesperado. As situações constrangedoras para o gago vão se acumulando. A mais pungente é, sem dúvida alguma, o gesto final, onde o pronome 'tu' dá origem a uma bravata melódica: $t u, t u, t u, t u$, tu ,tu ,tu ,tu, tu tens....

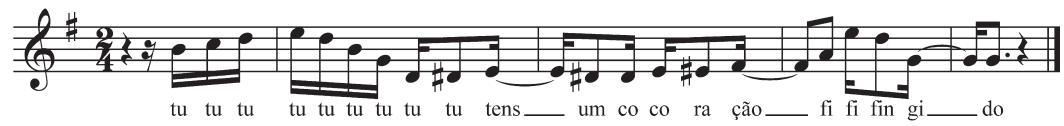

Qual não é a surpresa quando nos damos conta que esse gesto finalizante evoca uma cadenza de ária de ópera ${ }^{5}$. Ele navega pelos extremos da nota da Dominante (ré4 - ré3), e depois dos cromatismos de praxe, encerra com uma fórmula consagrada para arrancar aplausos das platéias: fi-fi-fin-gi-do.

Uma ária de bravura. O gago está bravo que nem só. Mas, ao mesmo tempo, é um gesto de samba. Sua rítmica chega a lembrar o samba de breque. Estamos em plena interface antropofágica?

Rindo do gago, estamos rindo também do cenário linguístico onde ele trafega - um romantismo de gosto duvidoso e soluções pie- 
gas. Vale lembrar que o personagem de 'Conversa de botequim' não precisa de nenhuma moldura parnasiana. Fala em 'manteiga à beça', em 'média requentada', ou seja, é a linguagem do cotidiano, da vida aliás, uma bandeira de Noel.

Mas o gago deriva parte de seu humor justamente desse absurdo. Alguém em sua condição, ainda ter que lidar com 'tu tens', 'teu coração me entregaste', 'depois de mim tu tomaste' - é demais para um pobre mortal. O gago acaba ridicularizando essa representação lírica que oblitera a realidade social em favor de 'uma hipocrisia que escraviza.' Que bálsamo ouvir o gago estropiar a sentimentalidade do 'co-co-ração'. Nesse sentido, a voz de Noel é modernista.

Por isso, os ritmos que desorganiza para criar o efeito da gagueira podem ser considerados como um experimento de crítica da representação. Como algo 'original', que nem os vizinhos ou papagaios conseguiriam reproduzir - tal como disse orgulhoso o próprio Noel a um jornalista.

Seriam, dessa forma, frestas de criação musical. E assim como a crítica da retórica vazia e a defesa da linguagem cotidiana prenunciam a bossa nova, esses ritmos tortos de gago, prenunciam essa incrível mania transformada em excelência e arte por João Gilberto, de imaginar que qualquer coisa pode ser tempo forte.

${ }^{1}$ Esta crônica contou com a leitura prévia e comentários de Tuzé de Abreu, que sempre pensou a música popular brasileira a partir da seguinte trilogia: Noel / Caymmi / Gonzaga.

${ }^{2}$ Sendo a figura do tirano seu contraponto necessário.

${ }^{3}$ Vale lembrar que o compositor checo Bedrich Smetana coloca no palco um personagem gago, na famosa 'The Bartered Bride'. Essa ópera foi muito badalada pelo mundo afora, inclusive no Rio de Janeiro.

${ }^{4}$ Lembro aqui de Mariana, nascida no interior da Bahia (Itiuba) e uma grande amiga da minha família. Ela usava essa expressão para fazer referência à ameaça feita por alguma mulher de capar um macho. Eis aí o pano de fundo da palavra 'estrago'.

5 Também aparentadas com as cadências da forma Concerto. 


\section{Terra}

Não há cosmonauta, simplesmente porque não há cosmos.

O cosmos é uma noção do espirito.

Jacques Lacan

Nós, do século XX, construímos o privilégio de vermos a Terra de longe e de fora. E ao vê-la assim desgarrada, parece que somos invadidos por uma ternura toda especial, uma ternura azul e branca. Como se a Terra fosse um espelho, e o que víssemos fosse ao mesmo tempo um berço e uma lembrança antiga. Uma divindade em órbita, e ao mesmo tempo, o mais recôndito umbigo.

É mesmo uma sensação radical de desgarramento, tal como aquela que nos aparece em sonhos, quando pairamos na beirada do teto, ou quando saltamos e percebemos com grande surpresa que estamos flutuando - tem gente que bate os braços como se fossem asas. Acordar desses sonhos é sempre difícil, ninguém quer...

Talvez por isso eles tenham entrado na agenda real das nossas narrativas, desde Ícaro. É preciso voar, dizemos a nós mesmos há séculos e séculos. É preciso ultrapassar essa força que nos prende e nos amarra ao chão. E, certamente um dia, será preciso navegar pelo espaço, abandonar o berçário Terra, e reverter apenas ao pó das estrelas. Flutuar é preciso.

Pois, essa me parece a maior força musical da canção Terra, de Caetano Veloso. Mais do que diz, o refrão da canção flutua, ou seja, 
coloca o ouvinte num certo estado de flutuação melódica (cante aí para lembrar, ou veja no YouTube):

Terra, Terra,

Por mais distante

O errante navegante

Quem jamais te esqueceria?

É muito mais fácil sentir que a canção flutua do que explicar como é que ela consegue isso. Na verdade, olhando mais de perto, verifica-se que a sensação não é apenas de flutuar, mas de planar, como se fôssemos descendo até encontrar o chão do último verso, na última sílaba da última palavra - (quem jamais, te esqueceria).

Esse, aliás, um tópico amplo e muito discutido atualmente. A capacidade da música de formar gestos e redes de significado a partir do movimento - ou melhor, das metáforas que esses movimentos oferecem. Um exemplo fácil de acessar na memória musical é o Danúbio Azul, de J. Strauss, que faz a nave flutuar e orbitar no espaço (no filme $2001 \ldots$..), mostrando que a valsa pode ter implicações siderais - e ninguém havia pensado nisso antes, até então ela servia apenas para rodopiar por aqui mesmo.

No caso de Terra, vários fatores contribuem para esse efeito planador. O mais fácil de mencionar é o tratamento da harmonia. Nessa canção, a Tônica (Dó maior) representa a chegada no chão (jamais esqueceria...), e é guardada a sete chaves, só aparecendo mesmo no final da linha.

A canção apresenta uma espécie de gangorra ao ouvinte. Primeiro uma subida íngreme (onde a harmonia estática utilizada é a Dominante, Sol). Vai recheada de espinhos melódicos (dó\# em sol) provenientes da utilização do modo lídio (adiante percebe-se que é lídio-mixolídio). Começa na "cela de uma cadeia" e vai até a visão erótica de alguém que estava "coberta de nuvens", e funciona como 
uma preparação e armazenamento da energia que vai ser dissipada logo após, no vôo suave do refrão.

Só depois de atingir o pico é que começa a descida melódica gradual em parceria com um movimento harmônico simples e singular - colocando a Dominante depois da Tônica, e não antes (o resultado é uma Tônica mais instável, que escapole facilmente para o retorno da estática anterior, na Dominante, a ponto do Songbook se confundir, registrando Sol como tonalidade da peça):

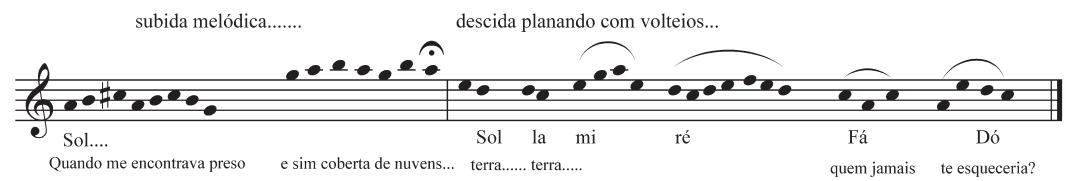

O efeito de planar também depende dos espaços vazios deixados na melodia. Observe como a palavra "terra" é tratada: a primeira sílaba curta e acentuada, a segunda longuíssima e fraca. Há sempre uma duração longa suavizando a descida (distante, navegante, jamais, esqueceria).

(a tentativa de preenchê-los com percussão em uma das versões no YouTube, mostra que essa escolha sacrifica a fluidez do efeito planador).

Os movimentos melódicos ou são descendentes (como em terra), ou em forma de arco (por mais distante, o errante navegante), ou seja, apresentam uma subida e uma descida, e são vitais para o controle do movimento geral, que desce de forma gradual, dando ideia de voo que plana.

Esse traçado composicional tem a complexidade das coisas simples. A ideia da peça extrapola a sonoridade da voz (embora a voz seja tudo) e mesmo a sintaxe dos acordes, para convocar a sonoridade da imagem e do sonho antigo. Mais do que a voz, é o sonho que soa. 
Desaprisionado pelas nuvens, esse leão de fogo acede à alegria de ser gente, planando no chão do real não sem uma certa nostalgia, uma nostalgia de navegador português, de Fernando Pessoa, e de São Salvador. 


\section{Isto é bom que dói! Notas sobre popular e erudito}

Notas para um ensaio sobre o popular e o erudito na música brasileira

Como se laçam ou desenlaçam o popular e o erudito na música do Brasil? Escolho um título que homenageia Xisto Bahia, um dos primeiros militantes da canção brasileira (final do século XIX), sendo esse um de seus sucessos, aliás utilizado como chamariz para biscoitos supostamente mais finos, tais como "Quis debalde varrer-te da memória”.

A reflexão sobre interfaces entre popular e erudito na música do Brasil não pode fazer de conta que esses são dois conjuntos independentes. Na verdade são dois conceitos multifacetados (e às vezes esdrúxulos) que talvez devam ser encarados como ficções, úteis como sinalizadores gerais, afinal Carlos Gomes não é Riachão.

Especialmente no caso do Brasil, não se pode pensar numa situação binária - erudito versus popular. E, mais importante ainda, não se pode garantir que a erudição venha sempre do lado da Europa. Por exemplo, no que diz respeito à complexidade rítmica, o material africano que chega ao Brasil tende a ser bastante sofisticado, apontando na direção de uma outra espécie de erudição.

A rigor, portanto, o repertório da música popular vai interagir com os repertórios eruditos da Europa e da África, e com o passar do tempo, a partir de esforço artístico de grande monta, vai ter de lidar 
com material 'erudito' produzido em seu próprio campo, tal sendo o caso, por exemplo, das interpretações de João Gilberto, que levam a precisão das escolhas até as últimas consequências.

Um dia desses vi Maria Betânia na televisão comparando música e perfume. Ambos provocam respostas sensoriais rápidas. Pois bem, é essa natureza sensorial da música que exige um conceito diferenciado de erudição. A sofisticação musical de seus processos de elaboração e aprofundamento dependem sim do intelecto, mas não apenas do intelecto cartesiano. Trata-se de uma inteligência que não pode excluir a audibilidade e o corpo.

Tudo isso vem a constituir uma primeira perspectiva no enfrentamento do desafio de visitar interfaces entre erudito e popular na música brasileira. Nomearemos essa primeira janela como perspectiva conceitual e de categorização - um esforço de repensar as bases do próprio desafio. A rigor, uma das melhores definições de povo vem de Affonso Romano de Santana: o povo é um ovo, depende de quem o põe ou quem o gala.

Uma segunda direção de ausculta vem da apreciação de trajetórias bifrontes (ou trifrontes) de vários de nossos heróis musicais. Podemos facilmente listar dezenas de percursos complexos entre o que se chama de erudito e popular. Vamos batizar essa frente de percursos e vínculos.

Alguns exemplos gritantes: Ernesto Nazareth, Patápio Silva e Chiquinha Gonzaga - todos com formação 'erudita' no período de plasmação do chorinho. Pixinguinha (flautista e arranjador) e Villa-Lobos. Vicente Celestino (que vem da ópera italiana), Guerra-Peixe e Lindembergue Cardoso. Vinicius (poeta e diplomata) e Tom Jobim (aluno de piano e de Koellreutter), Radamés, Rogério Duprat, Tom Zé (aluno de Ernst Widmer), Egberto Gismonti, Antonio Nóbrega, Arrigo Barnabé, Wisnik, entre muitos. 
O caso de Vinicius de Morais é deveras especial. Sempre cultivou uma chama intensa de desconstrução modernista do discurso:

Meninas de bicicleta

Que fagueiras pedalais

Quero ser vosso poeta!

…

Vós que levais tantas raças

Nos corpos firmes e crus:

Meninas soltais as alças

Bicicletai seios nus...

A canção popular vai se constituir em um grande laboratório de novas experimentações. Classificaríamos esse dado em nossa terceira perspectiva, que reúne atitudes e olhares recíprocos. Vale lembrar uma bem engendrada frase de Tatit, citada aqui meio de ouvido: "a canção quer virar sinfonia, e a sinfonia quer virar canção".

Se existe uma atitude modernista na relação entre erudito e popular, haveria uma atitude pós-modernista? Uma atitude nacionalista?

Para a última janela guardo as questões mais técnicas, as marcas e processos. Marcas herdadas ou adquiridas pelos repertórios enfocados, e os processos musicais/composicionais envolvidos. Um exemplo: a herança das métricas binária e quaternária da música ocidental, e a necessidade de reconstrução dentro desses arcabouços de tempo dos esquemas de duração africanos, pela via da acentuação deslocada.

Aí está: um horizonte de quatro perspectivas se oferecendo como scanner de tão envolvente questão. $\mathrm{O}$ assunto mal se inicia. Continuaremos em outra oportunidade. 


\section{Chico, Mané e Beiçola}

todos três na corriola

Chico é o leitor, Mané o editor, e Beiçola é quem escreve. No jargão de hoje, produtor de conteúdos.

Não, não. Melhor mesmo é colocar o Beiçola como leitor. Consumidor tem ou não tem cara de Beiçola?

Pode até ser engraçado, mas quem vai ler insulto? Deixa o criador ser Beiçola, fica mais fofo.

Só tem esses dois jeitos, porque o editor tem que ser o Mané. Ele tá no meio, e não tem nada a ver com a ingrisilha. Como não? Ele não é amigo do Gandola?

Mas o Gandola não faz parte desse jogo - só virou folclore depois do Jô.

Nesse jogo da corriola, o mestre vai impondo a cada pessoa uma sentença, e ninguém deixa a roda sem cumprir a lei: "cantar como galo, grunhir como porco, cacarejar de galinha, mugir de vaca, rezar uma oração, abraçar alguém...” (Danças e Ritos populares de Taubaté, p.39).

Você quer dar ares de semiose digital pra Chico, Mané e Beiçola - só porque a expressão não existia em nenhuma máquina de busca - mas combinou com o pessoal dapuc (?), vai dar rolo -, e no Aurélio o que aparece é outra coisa: arruaça e motim de rua... 
Não tire atenção da beleza da imagem. Muito mais intensa que galos tecendo uma manhã. Temos aqui também porcos, galinhas, vacas e abraços, tecendo manhã, tarde e noite, nessa rede global de teúdos e conteúdos.

Escafedeu-se a obra-prima, perdeu a forma. 240 canções do robierto (deixa assim, Mané!) num único suporte, meu amigo comprou. Pra onde vai a obra, ora a obra não vai pra onde ia?

socorram-me, subi no... ônibus, em Marrocos

Acaba a exx-clusividade da obra? Os fãs, esses Beiçolas empedernidos, querem virar Chico - ou vice-versa. Os Beiçolas querem ser gente. Produzem suas obras-b com grande entusiasmo: "posso divulgar o meu blog?".

Uma galinha grunhiu na Austrália.

obra-b, c, d, obra-r, rabo brabo de obra: abób-obra. Os Beiçolas e o fim de repertórios canônicos. Beiçolas do mundo, uni-vos! E assim transito da semiose para o valor da rebeldia. Inventem uma geringonça diferente que a gente possa chamar de mundo. Já!

E talvez, o que um dia foi arruaça, num lugar desigual e violento como a Bahia do século XIX/XXI, tão bem pintada por João José Reis* e seu relato da vida do liberto Domingos Sodré, possa mudar...

Foi certamente um ambiente desse tipo que cravou na expressão seu viés de censura - entre brincadeira e motim, os três são denunciados. E cabe ao não nominado o maior peso nessa história.

A culpa é do Beiçola? - uma marca de preconceito contra esse personagem sem nome que ameaça intervir no jogo? Afinal, ele é o único que rima com 'curriola' (fala-se assim), e vem no final da denúncia, recebendo todo o peso rítmico e métrico... 
(Quantas mortes violentas já ocorreram no Brasil em $2009 \mathrm{em}$ função de curriolas do mal? $450 \mathrm{em}$ Salvador.)

A minha obra-b está pronta. Agora pensem em outras crônicas que tratariam de novas possibilidades: eleitor, mídia e políticos (Chico, Mané e Beiçola); os três macaquinhos; o antes, o agora, e o depois (que Beiçola terrível seria o depois) o espírito, a alma e a mente (obrigado, Pedro!) a tese, a antítese e a síntese (êta, Beiçola danado!) a trindade, o ego, o super-ego e o id (um Beiçola intratável...)

Entro por uma porta e saio pela outra...

* Imperdível o livro do grande historiador baiano, com as teias de resistência e vida traçadas na Bahia do século XIX, editado pela Companhia das Letras. 


\section{Ensaio do Trio}

Para! Para!! Para o carro, Olegário!!!

Não tá vendo que tá andando de banda?

- Mas Seu Osmar, o carro já quebrou há muito tempo,

é o povo que está empurrando!

(famoso diálogo entre Osmar Macedo e o motorista da fubica em 1951)

O ensaio, como tradição literária, é esforço interpretativo; o que dizer de profundo sobre o trio elétrico? Tanta espetacularidade dispensa maiores justificativas? Neste ensaio, persigo o ideal formalista de fazer coincidir forma e conteúdo: um discurso com três pontas (trio) e uma questão-síntese

A primeira ponta é o frevo. Há uma ligação de umbigo entre trio elétrico e frevo pernambucano. Dodô e Osmar tiveram a ideia de colocar a tal fubica na rua em 1951. Poucos dias antes passara por Salvador o Clube Carnavalesco Vassourinhas, de Recife, em direção ao Rio.

O frevo traz marcas indeléveis da herança afro-brasileira. Não tem nada de africano na melodia ou na harmonia, poderia ser tocado até como minueto! Mas os ritmos!!! As ideias rítmicas impingem aos compassos da Europa acentos e tensões que são tipicamente brasileiros. Imprescindível para o espetáculo. Imagine se funcionaria com música de valsa? Tem que ter malandragem... 
Mas aí surge um fino detalhe. E essa é a segunda ponta do argumento. O carnaval que predominava nas ruas de Salvador até então era o do corso e dos préstitos - o desfile das beldades de elite com fantasias e acenos do alto de carros especialmente preparados para a ocasião.

O povo ficava na Barroquinha e na Baixa dos Sapateiros em cordões e afoxés. Consta que em décadas anteriores, até ópera italiana era usada nesse carnaval dos mais ricos.

Portanto, a presença da fubica, tocando frevo, era uma subversão enorme. E o cerne da subversão era que o frevo colocava como centro das atenções o próprio povo dançando. $\mathrm{O}$ corpo.

Quem já assistiu à passagem de um trio elétrico trazendo em torno de si todo o repertório humano de um bairro popular saberá do que estou falando. Encantamento total na junção entre música e dança.

O calor e a euforia são tão grandes que alguns tiram a camisa pra rodar por cima da cabeça. Tem casais abraçados, crianças montadas no pescoço dos pais, gente de meia-idade, mulheres em grupos, vendedores ambulantes vendendo e dançando, disputa pra ver quem faz a melhor pirueta, e aquele empurrão no meio do bolo...

Os ritmos afro-brasileiros oferecem situações de equilíbrio e desequilíbrio, convocam o corpo em movimento, o rebolado. Esse, aliás, o espírito que Caetano celebra através do verso 'só não vai quem já morreu’.

Portanto, naquela virada de 1951, algo mudava na Bahia do governador Octávio Mangabeira, figura maior da nossa vida democrática. Um 'momento histórico' proporcionado pela bolha democrática entre o Estado Novo e a ditadura de 64?

No modelo que daí surge, o espaço público vai ser ocupado mais democraticamente. E essa energia vai favorecer uma qualidade musical diferenciada, embalada pelo virtuosismo do frevo e pela "li- 
vre" aventura de botar uma música na boca do povo. Caetano, Moraes, Armandinho... A terceira ponta do discurso relembra Manoel José de Carvalho. Para ele, as dinâmicas de rua são construções sociais com enorme peso histórico. A cidade de Salvador teve 300 anos anteriores de experiências com o cortejo de rua. Principalmente no contexto religioso, com procissões e festas de paróquia.

$\mathrm{O}$ aparecimento do trio acaba mobilizando essa memória grupal histórica pelas ruas da cidade. $\mathrm{O}$ trio se encaixa na dinâmica ancestral construída em torno do andor das procissões. É como se tudo estivesse pronto aguardando sua chegada.

Nos anos seguintes vai ocorrer um processo espetacular (e muito original) de design para a festa, da carroceria de um caminhão, até os nossos fulgurantes monstrengos de hoje - grandes palcos ambulantes.

Síntese:

Hoje estamos em outro planeta: cordas, cachês e abadás. E mais: camarotes e celebridades. Ganhou-se em gestão, profissionalização e expansão. Perdemos em participação, diversidade e qualidade musical.

As músicas não ficam mais no ouvido durante anos, estão congeladas em sua funcionalidade homogênea... Aliás, a funcionalidade excessiva ameaça congelar quase tudo (raras exceções).

Será que o impulso democrático dos últimos anos, essa bolha que esperamos definitiva, vai ter a força e o discernimento para fazer brotar um novo modelo que recupere as coisas perdidas?

Mais do que questão, uma demanda: multiplicar os ganhos (socializando-os) e potencializar a qualidade/diversidade cultural.

*Este texto contou com a leitura prévia de Paulo Miguez. 


\section{Michael Jackson e a fabricação de si mesmo}

"Homens promovidos ao estado de produto"

Mais do que qualquer característica pontual - voz, repertório, gênero - a construção de Michael é o personagem. Seus clips provam isso. E que personagem seria esse? Por que exerce um tal magnetismo?

Podemos evocá-lo facilmente através do estilo de movimento, uma cinética toda especial, uma dança eletrizante, mas aparentemente disforme, dança sem lei que faz o corpo andar para trás, amolecer que nem borracha, deslizar sem gravidade. As crianças piram: seria um Chaplin trans-figurado pela pós-modernidade?

Esse personagem que canta e dança, atrai para si os adereços mais incríveis. $\mathrm{Na}$ verdade ele configura o corpo como adereços - e naquele famoso sacolejo de quadris que sempre emoldura uma pegadinha radical, parece nos dizer que o próprio pênis é um adereço -, existiria irreverência maior? Aponta para uma sociedade do adereço?

Com isso, personifica a rebeldia e a "aventura" na terra do sem-limite, sua neverland interior, seu rancho permanente, de onde nunca pôde sair. Preso a um intrincado processo de fabricação artificial de si mesmo - impedido de seguir o caminho da identificação com um pai violento - transforma essa auto-fabricação, suas misérias e 
delícias, no foco de atenção midiática. E faz isso de forma incomparável com o talento que tem.

Repete compulsivamente esse fantasma de que não há pai, de que ele se inventa sozinho - tal como seu personagem. Seu magnetismo viria dessa aparente libertação (projetada por um talento incomum)? Olha que isso vale tanto para a dimensão ficcional como para o MJ real, que apresenta seu filho ao mundo de maneira esdrúxula, do alto de um hotel. Aparentemente não há registro do que é um filho. Como poderia haver?

Preso nessa condição, enxerga-se/ama-se em todos os meninos, no quase delírio dessa horizontalidade fabricada, onde ele também é um deles. Mas a onipotência da fama bate de frente com o sintoma - no final das contas ele realizou o desejo do pai, tornando-se o mais famoso da família. Esse conflito deve ter exigido medidas drásticas.

Ignora a genética e fabrica-se branco - não há limite. Envolve-se, portanto, numa intricada desconstrução impossível de sua negritude, que grita por todos os seus poros, em cada jeito de corpo, em cada foto de família. Dolorosa travessia ao nada da impossibilidade de identificação. Um nada que insiste em estar presente - hoje já não aceitaríamos o Michael negro de volta. Sua transgressão parece ter vindo para ficar.

Imaginem uma celebridade futura, já no auge das manipulações genéticas... O que aprontaria? Não é justamente isso que aquele famoso clip "black and white" anuncia, fundindo dezenas de faces?

Ora, MJ não é apenas o ídolo que morreu outro dia, mas também o conjunto bilionário de todas as representações que dele fazemos. Representações vivas que se materializam em covers espalhados pelo mundo afora. Quem não gostaria de deslizar eternamente com aquele gingado?

E ao oferecer ao mundo seu processo de fabricação artificial de si mesmo como objeto de adoração, está absolutamente alinhado 
com a necessidade pós-moderna de desvinculação da instância terceira de um Outro - pai, pátria, religião, instituição, causas sociais e políticas, moral, etc. Comove-se o mundo justamente porque houve pelo menos Um sem pai?

E está também alinhado com as boas práticas do mercado. Um mercado para o qual a auto-referência representa o caminho da maior lucratividade, pela via da globalização, que se entranha nesse declínio do Outro através da flexibilização econômica - atores sem nada acima deles que impeça a maximização das trocas.

Como sinal dos tempos, como ícone do capitalismo narcísico, de personagens que se auto-constroem - e que deslizam suavemente da neurose para as novas psicoses -, o percurso de MJ absorve diversos traços característicos da vã tentativa de remediar a carência do Outro:

a) o discurso para o bando, para a gangue (esse é o ambiente dos clips), onde se distribui a responsabilidade da "auto-fundação";

b) o impulso para a adição (mesmo que pela via da medicalização ou do consumo), um recurso imprescindível para enfrentar depressão e dor;

c) os signos da onipotência tão comuns ao estrelato;

d) um implacável enfraquecimento do espírito crítico (não há a quem prestar contas), daí para o endividamento, um passo;

e) as novas formas sacrificiais e a manipulação do corpo;

f) a negação da diferença sexual e geracional;

g) a exposição da vida íntima como artifício de mercado (prenuncia os blogs).

Do ponto de vista das mercadorias, MJ representa um ponto culminante no processo de fetichização. Foi aí que ouvi do meu amigo João Carlos Salles a famosa tirada do velho Marx, sobre a di- 
mensão imaginária da circulação de produtos, na direção do fetiche (futuro inexorável do capitalismo): as mesas vão dançar...

E nós, o que faremos sem essa pirueta fantástica fingindo ser coisa nossa? Agora deve estar deslizando pelas nuvens afora.

${ }^{1}$ Flexão pós-moderna de uma famosa crítica ao capitalismo: "homens reduzidos ao estado de produtos"

${ }^{2}$ Cf. Dufour, A arte de reduzir as cabeças. Editora Companhia de Freud. 


\section{Alguém pode querer me assassinar poder e paranoia}

Mamãe, não quero ser prefeito, pode ser que eu seja eleito e alguém pode querer me assassinar. Eu não preciso ler jornais, mentir sozinho eu sou capaz, não quero ir de encontro ao azar.

O poder é um lugar de paranoia? Para Raul Seixas a conexão é bastante palpável. Uma breve inspeção dos significantes/personagens de sua canção "Cowboy fora da lei" nos leva diretamente ao contexto, e o título já nos fala das relações entre lei, heroísmo e transgressão.

Aquilo que parece ser apenas um balacobaco inofensivo com banjo e coisas do velho oeste, oferece como ponto de partida um diálogo pra lá de delirante, envolvendo ninguém menos do que mamãe - “mamãe, não quero ser prefeito". Vamos e venhamos: combinar mamãe e Velho Oeste é uma raridade excêntrica.

Aliás, a canção reúne personagens improváveis: Durango Kid, Jesus, mamãe e papai, o cowboy fora da lei, um assassino aleatório, um prefeito recém-eleito, Deus! Além de vários símbolos: o azar, a luz, a cruz, a lei, o heroísmo, a história, os jornais, o gibi, a pátria 
amada. Uma narrativa em forma de sarapatel que paradoxalmente flui sem maiores guinadas. Como consegue colocar tudo isso num mesmo saco?

Até que ponto a canção de Raul deve ser pensada como alegoria do campo do poder? E que elementos traz para a análise do imaginário da convivência política, para o imaginário das eleições?

Ao escolher o Velho Oeste como ambiente da política, e dizendo que não é besta para ser herói crucificado, estaria Raul pintando um cenário onde não há solução política? Herdamos das ditaduras, ou melhor, da nossa tendência a ditaduras, esse traço maléfico. Há quem diga que a canção se inspirou na tragédia que foi a morte de Tancredo Neves na década de 80 - uma época propícia para essa visão.

Não custa lembrar que o modelo da paranoia está presente em ninguém menos que Dom Quixote de la Mancha, e talvez seja uma abertura imprescindível para a modernidade.

$\mathrm{Na}$ canção, a abertura é estranha e cômica. $\mathrm{O}$ círculo lógico e delirante de personagens se impõe: mamãe, ser eleito/ser prefeito, alguém. Quando o eu lírico diz a mamãe, com voz de bezerro desmamado, que não quer ser eleito, está soando na tecla do desamparo. Mas, porque o desamparo? Ora, só faz sentido se por baixo dele houver desejo de ser prefeito, herói e entrar para a história...

Desejo esse que pode atrair diretamente o 'azar' de um tal 'alguém’. Alguém pode querer... olha que formulação maravilhosa! Quem pode negar uma coisa dessas? Alguém pode querer qualquer coisa. É uma frase ideal para o delirante justamente por não admitir contradição. Qualquer delírio consegue se justificar com essa tautologia.

A canção também registra esse incômodo com relação ao próprio cantar: "eu já servi à pátria amada e todo mundo cobra minha luz". Raul se queixava de que havia uma expectativa das pessoas de 
que ele realizasse milagres do palco. Interessa-nos marcar esse paralelo entre a celebridade artística e a política. $\mathrm{O}$ reconhecimento da transcendência de ambas, conectando a expectativa geral à sensação difusa de perseguição.

Tanto na canção como na vida política, ser eleito significa trazer a si, ou melhor, incorporar uma narrativa que circula no âmbito coletivo. Convocar a atenção, ou mesmo usurpar a atenção que potencialmente poderia ser de qualquer um.

Nenhuma eleição no hemisfério sul pode fugir da expectativa de lidar com a extrema desigualdade de destinos. E como essa desigualdade não aconteceu por acaso, teve um script, sua desconstrução requer traços de herói e ao mesmo tempo de transgressor.

A frouxidão do laço social e a prevalência da lei de vantagem própria fazem da periferia do mundo um lugar de maior desconfiança com relação ao poder, onde a raiva do líder aflora com maior facilidade. A linha entre herói e bandoleiro fica bastante tênue. A síndrome emocional ligando comandados e poderosos em torno da ocupação desse lugar central de decisão, apresenta peculiaridades e instabilidades próprias.

Esse sujeito que convoca o olhar, e que traz em si a promessa de avanço para uma situação melhor, também pode ser o mais novo sabidório de plantão, prestes a usar o poder em proveito próprio. $\mathrm{O}$ cinismo seria o avesso da paranoia? 


\section{Atirei o pau no gato}

Qual a emoção veiculada por aquela tradicional canção infantil 'atirei o pau no gato'? Podemos mesmo falar de uma emoção, ou seriam várias? Devemos aderir à antiga noção de que a cada música corresponde um determinado afeto?

$\mathrm{Na}$ verdade, música não tem emoção - nós humanos é que as temos, na presença de acontecimentos sonoros. O fenômeno é complexo, envolvendo uma negociação entre o repertório de referência de quem ouve e aquilo que está sendo ouvido.

Algumas vezes tudo depende do receptor. Lembro que o famoso tema de Ayrton Sena expressava a alegria da vitória, a euforia de ter vencido um enorme desafio. Mas, depois de sua morte, o tema passou a evocar uma dimensão trágica, que certamente não existia antes.

Não é que tenha surgido do nada. Nas próprias inflexões da euforia de antes, a nossa releitura encontrou respaldo para fincar a percepção da tristeza e da tragédia. Hoje ouvimos tudo misturado. A música em si não mudou - mudamos nós.

Portanto, músicas são verdadeiros novelos de emoção, guardando toda a história do envolvimento do ouvinte com o objeto sonoro. Não existiria, dessa forma, alegria ou tristeza puras, são muitas emoções, e olhe que nem estou citando o Roberto.

Voltemos ao gato. Sendo canção de roda, deveria traduzir emoções simples. As crianças se identificam de imediato com ela, desde o 
primeiro gesto. Aliás, está justamente nesse primeiro gesto uma alegria cinética especial. A alegria de ser capaz de atirar um pedaço de pau pra longe - coisa que as crianças pequenas adoram. É o único lugar da canção que flexibiliza a presença do tempo forte (no segundo tempo).

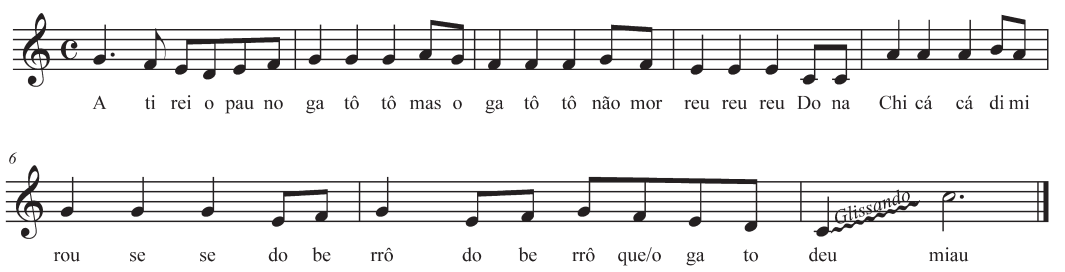

Trata-se, diria Freud, do impulso sádico como energia constitutiva do eu infantil - e a morte do gato como uma fantasia de onipotência, negada pela realidade - miau! É a única explicação para a formulação adversativa 'mas o gato não morreu'. Para o personagem infantil, atirar um pau pra longe tem essa potência presumida.

Porém, logo depois dessa flexibilização ocorre uma fixação excessiva do tempo forte, que parece garantir adesão total dos pequenos, uma verdadeira aula de marcação: ga-to-tô / rêu-rêu-rêu / chi-ca-cá...

Mas qual o papel de Dona Chica? Aparece de repente na canção como se fosse conhecida de todos. Obviamente seu papel é admirar-se. Ou melhor, assustar-se com o ocorrido. Seu nome tem o peso de uma testemunha acima de qualquer suspeita.

Mas a verdade é que acaba introduzindo a diferença (o espanto) no discurso musical: surge com um salto melódico de sexta, algo muito diferente da orientação anterior, toda por grau conjunto. Também interrompe a descida gradual (schenkeriana) que teve início na nota sol (sol / fá / mi...), levando a melodia a subir antes de sua conclusão em dó. 
A melodia vai migrando da familiaridade do início para uma representação do espanto que domina o final. Trata-se, dessa forma, da construção sorrateira no ouvinte-cantante do mesmo susto que apavora o gato.

Esse final escandaloso domina emocionalmente a canção, pois é o ponto para o qual todo o discurso converge (inclusive o musical). Afirma e nega simultaneamente a onipresença do tempo forte, dá consequência ao espanto anunciador de Dona Chica, e libera a adrenalina do berro final (numa espécie de contratempo).

Se o início da canção está focado na força ativa, de dentro para fora, o final faz o percurso contrário, desemboca na recepção. De todas as emoções possíveis, fico com a mais correta politicamente: a descoberta fascinante de que aquilo que afeta o gato também me afeta. 


\section{A música e o striptease}

Procurei uma expressão em português, não encontrei. $\mathrm{O}$ mais próximo seria 'despir e provocar', que de tão insosso não serve pra nada. Fiquemos com o anglicismo e com o desafio de esboçar uma erótica da música.

A rigor, sendo a música erótica em si mesmo, não se trata de esboçar nada, apenas denunciar as artimanhas sonoras de sedução que a constituem.

O que deseja um ouvinte? É justamente desse striptease que se trata. Dessa capacidade travessa de ir se desnudando no tempo. Como se soubesse o que deseja o ouvinte. E aparentemente sabe.

Beethoven, ao escolher o poema de Schiller, 'An die Freude', para sua nona sinfonia, faz reverberar um impressionante discurso sobre a alegria como centelha divina (Gotterfunken...), como força que move o universo.

Lá pelas tantas, diz o poeta: até aos vermes foi concedido o prazer. A imagem é contundente: o prazer dos vermes, sua alegria, é a mesma nossa.

Os fios dessa cadeia vital de alegria que une vermes e estrelas passam pela nossa vida, e certamente iluminam a música. Daí, seu erotismo. Quem é o criador de música? É justamente aquele neto de Freud que jogava um carretel de linha para longe e para perto, encenando com o pequeno jogo os sumiços e aparições da mãe: Fort / Da 
(sumiu / eis aí). Trata-se de um striptease materno, só que é a mãe inteira que aparece e desaparece por entre as artimanhas do jogo.

Muitas estratégias composicionais lidam diretamente com o pólo visível do objeto sonoro desejado, o 'eis aí. Outras estratégias cuidam do sumiço, de tudo que vai garantir o prazer do retorno.

A tão desejada cadência harmônica está certamente no âmbito do 'eis aî. O samba é organizado como equilíbrios e desequilíbrios rítmicos que permitem ao ouvinte gozar simultaneamente com sumiços e aparições do tempo forte.

Você se lembra daquela famosa canção: 'meu coração amanheceu pegando fogo...? O desenho melódico empurra pra cima, sempre pra cima. Trata-se da necessidade de caracterizar o patamar de chegada - 'fogo, fogo...' - como pico de excitação por causa da morena...

Exemplos abundam nas músicas de todos os tempos. Até mesmo na peça silenciosa de John Cage (4' 33”) onde nada se ouve do pianista. A peça expõe o jogo do strip-tease mostrando a fera, o verme, a estrela desejante dentro de nós. 


\section{Farofa de tanajura}

Ivete ou Carla? Marlene ou Emilinha? Brahms ou Wagner? Perotinus ou Leoninus (conhece esses caras; acho que são metais...)? Jovem Guarda ou MPB? Rock, ou Samba, ou Reggae? Tonal ou Atonal? Ópera ou Sinfonia?

$\mathrm{O}$ amor da música. Escrevo no embalo de uma sempre inalcançável teoria das preferências musicais, que aponta para um vasto domínio - aquele que pode ser imaginado entre a fantasia intimista, a teoria da música, o sistema de decisões da mídia e do consumo, a psicologia, antropologia, sociologia, informática, política e, por que não, alguma metafísica...

Se alguém ama uma música (e alguém sempre ama uma música), então pensa que a tal tem determinados atributos, embora, evidentemente, não saiba muito bem quais são. Como se vê, o assunto é nebuloso mesmo. Mas também é muito prático, rolam milhões de dólares.

Diante da vasta capacidade de amor musical das comunidades humanas, não houve alternativa para a indústria cultural: controlar a oferta, moldando-a de acordo com as intenções de lucro. O resultado não é muito distinto da perda de biodiversidade com a queima das florestas.

A humanidade construiu em cada canto do planeta verdadeiras florestas sonoras, cheias de ideias musicais criativas. E, além disso, desenvolveu no Ocidente o fenômeno da vanguarda que valoriza a 
criação de novos mundos sonoros. E embora tenha sido o século XX aquele que mapeou o mundo sonoro e que estimulou as vanguardas, foi também o século da implementação de um sistema globalizado de homogeneização da oferta.

Mas o jogo não está perdido. A maré das novas tecnologias parece introduzir uma saudável dissonância nisso tudo. Se o lucro caminhasse junto com a felicidade da diversidade, não precisaríamos de outra utopia ou aliteração, e nem de criticar o capitalismo.

Mas voltando ao amor musical - que é o tema mesmo da farofa -, vale observar que ele tem sua cegueira, que é justamente não permitir que quem ama entenda porque ama, e nem se veja como parte ativa no ato. Você consegue explicar porque gosta das suas músicas mais amadas?

Pois é, a música também é vítima dessa síndrome do amor-objeto. E a música não é exatamente um objeto, ela é mais uma relação, um “estar-na-presença-de”. Então, você não ama um objeto, você ama a si mesmo na presença de... Evidência de um narcisismo estrutural que opera com a audição.

Aliás, esse é o mecanismo que a indústria explora, através das celebridades. Ao estimular que o superego dos consumidores se alinhe com a celebridade, desencadeia um amor de identificação, e esse amor de identificação tem como veículo predileto a música.

Amar uma música é como entrar num chuveiro. A água que vai passando pelo seu corpo é a música que lhe envolve. Pense aí em quantas águas distintas você já se banhou.

O problema das preferências musicais é um problema fantástico. Desemboca diretamente na questão da educação da sensibilidade (ou da insensibilidade insensata).

Como será o amanhã? Entre vanguardas e celebridades, como arrumaremos o mundo sonoro? 
Espera-se que com o "fim da História", com a descoberta de milhares de perspectivas pelas quais se pode organizar o passado, as direcionalidades fabricadas possam explodir em milhares de fragmentos pós-modernos que, como uma espécie de farofa de tanajura, nos aparece para o jantar.

Bom apetite! 


\section{França-Brasil Allons enfants da pátria amada}

Os textos não são coisas fechadas e autônomas como tantas vezes nos acostumamos a pensar. Eles dialogam entre si, e mesmo já nascem como respostas a outros textos - de antes e de depois! Pas$\mathrm{mem}$ ! Isso acontece porque ideia não tem casca.

Os países também não. São textos - o que significa que são intertextos. O bode que deu, vou te contar (você conhece esse verso?). $\mathrm{O}$ fato é que parece perfeitamente possível cantar o primeiro verso do hino francês seguindo com o segundo verso do hino brasileiro, sem tirar a beleza de nenhum dos dois ${ }^{1}$, que lá isso eles têm de sobra:

Allons enfant de la patrie / De um povo heróico o brado retumbante...

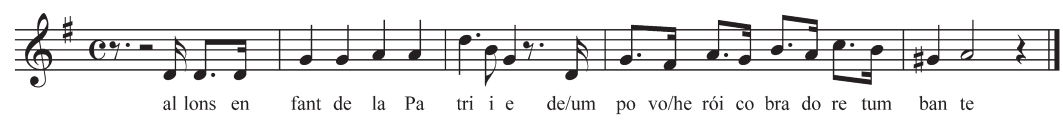

E se o nosso hino se enrosca de alguma forma na Marsellaise (de 1792), temos que colocar na roda o Francisco Manuel da Silva, seu criador - aliás, criador não, não havendo textos autônomos não há autores autônomos, somos todos sinapses ou encruzilhadas (a intertextualidade parece ser coisa de Exu, aquele que abre os caminhos). 
Era 1831, e D. Pedro I voltava para a Europa depois de um desenlace doloroso. Francisco Manuel era ativo 'liberal' e participou com garra dos dias agitados que precederam a abdicação. Na época, os ideais veiculados pela revolução francesa eram farol e espelho. A melodia que viria a ser o nosso hino foi feita nesse quadrante, para comemorar essa tal libertação. Razões de contexto não faltam para unir os hinos.

Depois de composta e executada em 1831 (provavelmente com outra letra), a música vagou pelo Século XIX, aparecendo em várias ocasiões. Só foi reconhecida formalmente em 1890. Nesta data, já na República, havia até sido instituído um concurso para escolha do Hino Nacional. Mas consta que Deodoro bateu pé firme pela manutenção do antigo ${ }^{2}$. A letra só surgiu em 1909, composta por Osório Duque Estrada, em clima e estilo totalmente diversos. A Leopoldina virou trem...

A base teórica desse enroscamento melódico entre os dois hinos vem da noção de contorno - que é o perfil de movimento dos gestos musicais:

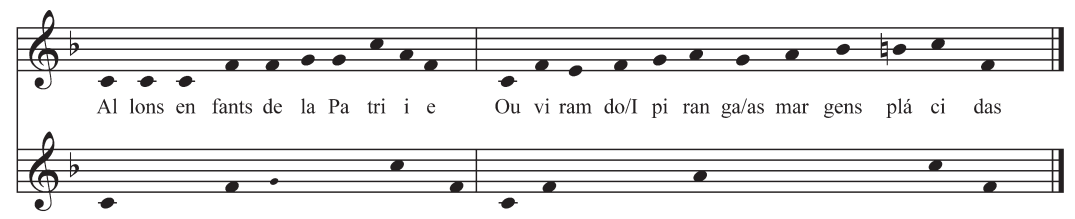

Observar a mesma estrutura melódica de apoio

As duas melodias apresentam o mesmo perfil, ou seja, um contorno que sobe uma oitava e desce uma quinta. Além disso, tem anacruses muito iguais (dó-fá). Esse gesto impetuoso de subida lembra o idioma dos clarins, e com ele tudo que representamos como heróico e glorioso. 
Mas há um diferencial importante que é o rebuscamento cromático. Aquele si natural que pirraça o ouvinte até a resolução na nota final - e que Fafá de Belém levou ao extremo em sua versão intimista quando peitou a Campanha das Diretas (1984) -, é uma marca do nosso hino. Permitiu a convocação de palavras proparoxítonas - margens plácidas - para enfatizar essa idiossincrasia (talvez uma inspiração de Chico, em 'Construção').

As ligações melódicas cromáticas vão se multiplicando no hino. Os próximos versos convocam as notas fá\#, dó\#, sol\#, (todas estranhas ao seu campo tonal imediato) e agregam outra proparoxítona - raios fúlgidos.

De onde vem esse cromatismo com jeito maneirista? Se tivesse que apontar um caminho, diria que lembram claramente fórmulas de finalização bem caras à ópera italiana - que por sua vez parece ter absorvido esses tais 'maneirismos' das finalizações do classicismo vienense (vulgarizando-os só um pouquinho, na medida em que a voz pungente vulgariza o mundo sublime da música instrumental; ou será o contrário?).

Ou seja: Rossini, que era muito ouvido no Rio de janeiro do início do século XIX ${ }^{3}$, absorve do período de Haydn e Mozart as tais finalizações cromáticas que acaba passando para Francisco Manuel. Este, aliás, sempre sonhou estudar na Itália (e D. Pedro I havia prometido enviá-lo pra lá, mas não cumpriu...).

De Rossini e Manuel Francisco a Deodoro e Olavo Bilac (que não havia entrado na história), o que aconteceu com nosso belo hino não é muito diferente da letra do famoso samba de Stanislaw Ponte Preta (Sérgio Porto), onde Chica da Silva obriga a Princesa Leopoldina a se casar com Tiradentes, e este, depois eleito como Pedro Segundo, reúne-se ao Padre Anchieta para proclamar a escravidão.

Oh,Oh,Oh,Oh,Oh,Oh: o trem tá atrasado, ou já passou... Viva a Intertextualidade! 
${ }^{1}$ Dá também para fazer o contrário, começar com o primeiro verso do hino brasileiro e emendar para o segundo do francês: Ouviram do Ipiranga às margens plácidas / Les jours de gloire sont arrivée.

${ }^{2}$ Aquele que ganhou o tal concurso virou o Hino da República.

${ }^{3}$ Cf. Vasco Mariz (2005, p. 67) registrando a encenação de: Il Barbieri di Siviglia, La cenerentola, L'italiana in Algeri, La graza ladra, todas gozando de enorme popularidade. 


\section{Caminhos da análise musical}

O leitor provavelmente pouco se dá conta do quanto já foi escrito e pensado sobre análise de música - ou seja, sobre as diversas maneiras de explicar o que está acontecendo quando se ouve música. Como funciona? Por que soa assim, ou assado? O que significa?

Todas essas questões (e muitas outras) aparecem quando o desafio é ampliar os horizontes do entendimento humano sobre esse fenômeno. Há textos complexos sobre o assunto desde a Grécia Antiga - pelo lado do Ocidente.

Aristóxeno, aluno de Aristóteles, nos deixou um belíssimo tratado sobre o ritmo: Como entender o ritmo? Quais os seus principais componentes? Como analisar algo que não permanece quieto num lugar, vai passando e levando nossa atenção junto com ele? Como dividi-lo em vertentes de estudo? - são questões sobre as quais ainda não há consenso.

Mas foi só a partir dos últimos duzentos anos que o discurso ancestral da teoria da música - que enfocava explicações do tecido musical de forma mais genérica, sem se deter sobre obras individuais - foi se diversificando em abordagens analíticas específicas.

A teoria da música cultivava abordagens amplas - regras de contraponto, encadeamento de acordes, ornamentação, etc. A análise musical surgiu para fazer jus à individualidade da obra. Na verdade, só pôde surgir a partir do momento em que a própria noção de obra de arte passou a ser prioridade - evidentemente, coisa da 


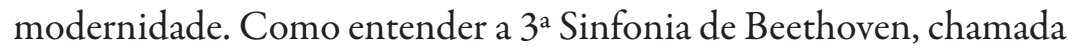
de "heróica"? Como Beethoven construiu sua unidade interna?

Pois é, a partir do final do século XIX foi ganhando força a ideia de que as chaves de explicação da música estavam dentro dela mesma, e não do lado de fora, em algum programa ou força extra-musical. $\mathrm{O}$ líder dessa corrente foi Hanslick, e sua pregação meio que hipnotizou o século XX.

No século XX os melhores esforços foram dedicados ao desenvolvimento da ideia de estrutura em música. As estruturas da música seriam, portanto, entidades analíticas deduzidas do próprio texto musical: estruturas harmônicas, por exemplo, ou reduções revelando entidades capazes de sintetizar o percurso realizado.

Uma outra noção muito potente vem reforçar esse campo de estudo e de invenção - a ideia de que há células musicais, pequenos motivos ou formas básicas que se diversificam ao longo do texto musical, garantindo unidade, coerência, economia de meios - tudo de bom no ideário do analista moderno.

Mas eis que a partir dos últimos vinte anos vai surgindo uma tendência contrária a essa lógica estrutural e organicista (ou seja, oriunda do desenvolvimento de células e motivos). O que vemos hoje é uma diversificação quase que espetacular dos discursos analíticos sobre música.

A primeira transformação a merecer registro é a repotencialização do contexto como fonte de insights, e mesmo de modelos preciosos para o entendimento da música.

Se o analista moderno típico buscava entender a ordem e unidade internas da Eroica de Beethoven ( $3^{\text {a }}$, o analista de agora pretende conectar essa visão estrutural ao melhor entendimento possível das representações sobre heroísmo na época da criação da Sinfonia.

Um breve levantamento de áreas de construção teórica, na direção de novos modelos analíticos, apontaria o seguinte: 
a) a esperança renovada de que modelos de análise da linguagem possam ser transpostos para o entendimento de música; comparecem aí os enfoques da narratividade, do desenvolvimento de uma semiótica da música, a revisão apurada das relações entre texto e música, intertextualidade, etc;

b) a esperança de que modelos cognitivos, ou seja, modelos que tentam entender como o cérebro humano processa o sinal música, possam contribuir de maneira diferenciada para o entendimento da música; por exemplo, através do uso de tecnologias recentes, tais como ressonância magnética e mapeamento do cérebro que ouve;

c) a esperança de construção de um painel mundial de culturas musicais, capaz de promover uma visão abrangente da criação, dos estilos e gêneros;

d) a esperança renovada de que novos modelos matemáticos e computacionais possam aprofundar o entendimento do fenômeno;

e) a esperança de suspensão dos enfoques teóricos tradicionais em prol de uma priorização da experiência musical; ou seja, a busca de ferramentas da fenomenologia, para tratar dos aspectos mais diretos da vivência sonora/musical - tempo, espaço, sentimento e jogo;

f) a esperança de produção de novos modelos a partir de diversas conexões interdisciplinares;

g) a esperança de construção de um meta-discurso sobre análise, capaz de classificar todos os discursos analíticos...

Entrei por uma porta, e saí pela outra... 


\section{Em nome de quê?}

Há uma surdez progressiva na sociedade, especialmente entre os jovens. Os professores não cansam de repetir pra si mesmos que os jovens parecem estar ficando surdos. Que já não ouvem nada do que falam. Como se continuassem com a televisão e o computador ligados durante as aulas.

Mas para Dufour (2003) essa surdez, mesmo sendo ampla, é seletiva - ela incide diretamente sobre a impossibilidade de se falar 'em nome de...' - e afeta de modo especial os professores. Oblitera o formato tradicional de veiculação de autoridade que se apoia nessa injunção simbólica.

Em seu livro A arte de reduzir as cabeças (Companhia de Freud), Dufour analisa cuidadosamente a importância desse lugar terceiro (em nome de...) que se faz presente na justiça, na política, na educação, aliás, o mesmo que aparece em conceitos como o 'Nome do Pai' de Lacan - a paternidade como metáfora para a formação do desejo e da ordem.

E, sobretudo, ele registra como as grandes mudanças de configuração da sociedade de hoje - da supremacia da mercadoria ao individualismo, e daí ao presenteísmo - estão afetando de forma profunda os processos de subjetivação (do tornar-se pessoa).

De como estão enfraquecendo um de seus mecanismos mais tradicionais, que é a conformação do sujeito a partir do discurso desse terceiro ausente. Conformação aí entendida não apenas como 'es- 
tar conforme,' 'estar sujeito a', mas também e especialmente como reação ativa a um certo limite - caminhando contra ele. Observa ainda como tudo isso incide sobre a formação de 'novos' sintomas: pânico, depressão, bulimia, adição.

Com essa progressiva vaporização do limite, os sujeitos enfrentam o desafio de construção de uma autonomia que não tem propriamente onde se sustentar. O exemplo moral ou religioso, a causa, a ideologia, o ideal de formação do espírito, tudo isso cedendo espaço para uma espécie de sem-limite do mercado e de novos prazeres e gozos - no embalo de novas tecnologias.

A questão é das mais relevantes e afeta todos os setores da sociedade. Suas implicações para a área cultural merecem reflexão contínua, até porque o capitalismo cultural vem transformando profundamente a cultura, numa direção que ainda não se sabe onde vai parar - há quem profetize que arte e publicidade se fundirão (e a expectativa soa assim mesmo).

Mas há uma questão específica que me interessa sobremaneira é a tal da surdez seletiva. A impossibilidade crescente de comparecer ao mundo da música sem o apoio do tradicional enunciador coletivo 'em nome de...' - santo guerreiro das tradições artísticas, do modernismo, das vanguardas.

A audição de músicas as mais diversas sempre envolveu essa ponte referencial. Ouve-se música em nome de um determinado estilo (pessoal, coletivo ou histórico), em nome de pertencimentos diversos (à cultura, a uma certa época, a uma tribo tradicional ou contemporânea), ou em nome de uma causa, e por aí vai. Há quem diga que esse pertencimento referencial é a própria definição da música.

A concepção tradicional de autoria envolve uma associação necessária entre o nome do autor e aquilo que sua arte representa. Com a fluidez dessa operação simbólica, esse tal engate parece ser um dos 
campos sujeitos a grandes transformações. E quem é o personagem mais representativo dessa nova quadra? Obviamente o DJ.

$\mathrm{O} D \mathrm{DJ}$ se pronuncia em nome de que causa? Sua performance alude ao contemporâneo (eletrônico) e relê o passado-vinil. Será que ele é o defensor da mixagem de tudo, da hibridação das culturas? Ou apenas um resíduo desse impasse contemporâneo - o representante mais puro da impossibilidade de falar em nome de quem quer que seja - investindo dessa forma numa multiplicidade desconstrutiva, que ainda assim (ou sobretudo assim) anima a festa?

Muitas vozes vão aqui se levantar para defender justamente o papel criativo do DJ, desde a escolha de repertórios até a produção de incríveis efeitos. Tudo bem. Concordo, mas estou mirando outra coisa.

O que me move nesta crônica é a identificação do DJ como modelo de nosso tempo - quero saber até que medida todos os criadores de música estão sendo transformados ou remoldados pelo papel e atratividade da função do DJ! Ou seja, até que ponto a capacidade de invenção de músicas está sendo empurrada na direção da arte do DJ?

Se tal for o caso, como devemos agir com relação a uma produção de qualidade que seguia (segue) outros parâmetros? Esquecê-la? Esperar pacientemente até que essa grande onda passe? Usar as espertezas de outrora nesse novo campo? Criar cursos de DJ nas universidades? Valorizar o ensino de mixagem tanto quanto o de harmonia?

É preciso lembrar dessa questão com cuidado para planejar o ensino de música em todas as escolas do Brasil. Mais do que o conhecimento de gêneros e repertórios, o que está em questão é a própria capacidade de ouvir, ou melhor, a escolha de escutas possíveis e necessárias. 


\section{A música e o espelho}

A música não diz tudo de vez. Se dissesse, não haveria porque ouvi-la de novo.

Ela parece existir dentro de uma perpétua contradição entre ser o sinal da inteireza de um determinado paraíso, e ao mesmo tempo, a evidência viva de sua incompletude.

Em um show da banda Cof Damu aqui em Salvador, fiquei junto de uma jovem que ao ouvir sua música preferida, pulava o mais alto possível, numa pungente agonia gozosa.

Seu corpo robusto - era pesada sem ser gorda - parecia querer flutuar nesses saltos expressivos - sempre alternados com gestos de quem estava tocando guitarra, logo depois bateria e, mais uma vez, saltos.

Aquele corpo parecia querer tornar-se música, e isso envolvia toda uma coreografia saltitante. Almejava flutuar. Lembro já ter sentido sensações semelhantes. Lembro, por exemplo, de uma coreografia magistral feita por Graciela Figueiroa para as Quatro Estações de Vivaldi. Inesquecível!

Talvez a música não diga tudo justamente porque na realidade se constitui como uma espécie de espelho, um espelho sonoro. Para Didieu Anzieu, esse espelho sonoro marca o próprio nascedouro do sujeito, embalado pela voz materna. 
Ora, esse espelho de som antecede em vários meses o estádio do espelho lacaniano, quando, através da imagem, o infante reconhece a si mesmo pela primeira vez - e sorri.

Muito já foi escrito sobre esse duplo de imagem que acompanha o nascimento do sujeito, e que paradoxalmente vem de fora - permitindo associar esse jogo de imagens com a fonte do conhecimento, da descoberta do mundo, e também, surpreendentemente, com a paranoia - o medo desse duplo que sabe sobre mim.

Anzieu, portanto, defende que esse jogo de identidade começa bem mais cedo, e não no plano visual. A identidade começa com choro, gritos, vocalizações de prazer, e tudo que a isso responde. $\mathrm{O}$ entusiasmo da música teria essa cena como ponto primordial.

Mas há um detalhe fundamental: se a música é espelho, é um espelho de tempo. Os jogos de identidade, do tornar-se e do destornar-se, da imersão em um campo sonoro, da aproximação ou afastamento de um centro tonal - todos tão caros à música, acontecem e desacontecem no tempo.

Ora, essas estruturas de identificação e reconhecimento transcendem o indivíduo. São matrizes utilizadas pelas coletividades para registrarem seus traços, seus ciclos e feitos.

Por isso, além de estar nesse curioso entrelugar de sujeito e objeto, a música também ocupa um lugar intermediário entre o indivíduo e o coletivo - sua comunidade mais imediata, ou a sociedade mais ampla.

Com sua realidade fugidia, a música nos embala e nos adia. Oxalá nunca termine, levando nossas almas, digo, nossos corpos, pelo incrível espaço da música das esferas... 


\title{
Sobre uma montanha invisível chamada música
}

\author{
Música... Se pudesse ter, \\ Não o que penso ou desejo. \\ Mas o que não pude haver \\ E que até nem em sonhos vejo, \\ Se também eu pudesse fruir \\ Entre as algemas de aqui estar! \\ Não faz mal. Flui, \\ Para que eu deixe de pensar! \\ Fernando Pessoa
}

Com o compositor, as coisas começam de maneira intimista, dentro da cabeça, imaginando, ante-ouvindo músicas ou ideias que às vezes chegam a se materializar, se é que podemos fazer uso dessa figura de linguagem.

A realidade, desse ponto de vista, parece tudo, menos real, porque ela surge como imaginação, mania ou devaneio, talvez até algo na direção do delírio - mesmo que seja o delírio obsessivo do controle de todos os parâmetros, ou o defensivo que escolhe um sistema para que este escolha a música - e progride daí para o que temos de mais material: ondas. 
A composição é, portanto, uma arte de antecipação do objeto sonoro, uma modelagem, e quem lá leu Die Verneigung, de Freud, sabe que este "Flui, para que eu deixe de pensar!", de Fernando Pessoa, é facilmente outra coisa, "Flui, para que eu não deixe de pensar", ou melhor, "para que eu pense sem me saber pensando...".

É o que faz Schopenhauer falar da música como um "jardim familiar e inacessível”, uma ponte privilegiada para o real primitivo e para tudo que não é ainda, nunca foi ou nunca será simbolizável, isto é, acessível à consciência com a lógica da linguagem falada.

Sendo assim, o passado extremo do corte que constitui o sujeito e o futuro implícito do desejo, se misturam e se confundem de uma maneira curiosa, esse um dos segredos da arte musical.

Está na ordem do dia perguntar pelo gozo da vanguarda, fazendo referência dessa forma à dificuldade antológica de abordar a relação entre prazer e música neste século que termina. Na Arcádia baiana dos anos sessenta, herdeira de algum Adorno via Koellreutter, Smetak e Widmer - confira "Grupo de Compositores da Bahia", na internet -, a questão da busca do novo apontava para o lugar do gozo.

Convivi com grupos que acreditavam que este paradigma seria absorvido pela sociedade em geral; restava investir e esperar. Gozava-se, como na ciência, com a descoberta/invenção de uma ordem escondida nos pedaços de caos a que temos acesso, com o poder fálico da reconstituição desse mistério de natureza divina, como nos diz o discurso de Descartes/Lacan.

O que o Grupo de Compositores da Bahia nos deixou de mais valioso foi justamente um investimento profundo nesta direção do gozo/ciência e ao mesmo tempo sua negação, a desconfiança em qualquer princípio declarado, um voto de anarquia que estabelece uma cumplicidade com o arquétipo de Gregório de Mattos e com os traços das culturas circundantes, com seus mitos e suores. 
Basta lembrar das máquinas/instrumentais de Smetak, da utilização que fez das cabaças, ou ainda do sentido de comunhão que o Ernst Widmer da década de oitenta buscava, para citar apenas dois exemplos.

Essa ambiguidade foi uma matriz pedagógica da maior importância, que apontava na direção desses tempos recentes, onde o sentido das dicotomias e superações parece ter sido ele próprio superado.

Não deveria ter sido tão grande o espanto de encontrar no universo rítmico do candomblé, com seus vários séculos de permanência, algo tão moderno quanto a teoria rítmica mais moderna. $\mathrm{O}$ conhecimento mais profundo desse universo passou a ser, para mim, um requisito indispensável na construção de uma contemporaneidade baiana.

O mais curioso é que os desenvolvimentos surgidos desse contato com o universo rítmico afro-baiano acabaram se encontrando com uma outra direção herdada do Grupo de Compositores, a valorização da variação como 'atitude de vida' musical; não apenas a variação como formato, e sim como procedimento, como exploração motívica, como elemento de construção de um discurso.

Mais do que os efeitos contemporâneos, esse é o elemento pivô do trabalho das décadas de 60 e 70, e representa uma ligação estável entre o trabalho baiano e toda uma corrente analítica deste século, derivada da ideia schonberguiana de Grundgestalt.

$\mathrm{O}$ universo rítmico do candomblé se associa muito bem a essa vertente, porque ele próprio pode ser concebido como um mosaico composto por unidades de duração elementar de 1 e de 2 tempos. Estudando padrões rítmicos afro-baianos aparentemente independentes como o Opanijé, o Ijexá e o Daró, vemos como podem ser facilmente concebidos tal qual variantes de um modelo básico, e como esse modelo básico está implicado também no Alujá, no Giká e no Barravento. 
Contornando toda essa disposição combinatória, o que temos é um investimento potente numa concepção de tempo que se afasta da linearidade ocidental na direção do êxtase. 


\section{Quem é você? \\ Carnaval e Psicanálise}

"Ser uma coisa é não ser susceptivel de interpretação."

Fernando Pessoa

1.

Colocando Descartes no meio da Timbalada, ou melhor, da Mudança do Garcia, no dia certo, ouviríamos uma variante nada ortodoxa da célebre máxima. Ele nos diria: rebolo, logo existo. $\mathrm{O}$ rebolado é condição do sujeito, significa literalmente girar sobre si próprio. Re-bola, bola duas vezes: jogo de cintura, se quiserem.

A Mudança do Garcia é uma das manifestações mais dispares e legitimas do Carnaval da Bahia. Sempre na 2a feira de carnaval, alguns milhares de pessoas saem pelas ruas acompanhando carroças com muita folhagem, gente fantasiada, batucadas refinadas, e um tom geral de anarquia e protesto. Vale tudo!

2.

O sujeito é um movimento e o desejo do Carnaval é o desejo de aceleração desse movimento, uma aceleração que caminha contra a ordem das coisas, que invoca uma espécie de mergulho na dissolução. Há, portanto, uma espécie de revolta no carnaval, uma recusa a ficar quieto, instalado e satisfeito, mas é uma revolta pela alegria. $\mathrm{O}$ 
Carnaval é uma sede, o que dá todo o sentido ao sucesso da canção de Brown, Água Mineral. O que a música pergunta é justamente isso: Tá com sede? Mas essa sede é outra, é uma outra sede.

3.

O saudoso arquiteto e fotógrafo Silvio Robatto, contava que um belo dia, tendo saído para fotografar coisas do Carnaval, no Centro Histórico de Salvador, foi surpreendido por uma chuva repentina e forte, dessas que acontecem por aqui. Chateado com a interrupção do serviço, entrou numa igreja para esperar a chuva passar. Qual não foi sua surpresa: o rebolado estava todo lá dentro da igreja, nas alegorias de anjos e santos feitos pelos escravos. A espiral do barroco e o êxtase do batuque podem caminhar juntos na Bahia. $\mathrm{O}$ barroco rebola, concluiu ele - e organizou uma contundente exposição fotográfica sobre o tema (Cf. O barroco no rebolado).

4.

Se o rebolado for encarado como uma forma de conhecimento - epistemologia do rebolado, do "aval da carne" -, então queremos saber que espécie de conhecimento é esse, o que é que se conhece no rebolado. Por outro lado, se admitimos o rebolado na categoria de conhecimento, então vamos dar uma certa dor de cabeça à epistemologia strictu sensu. Como é que o estudo das possibilidades de conhecimento se flexionaria a tal ponto: rebolado da epistemologia?

5.

Esse mergulho do Carnaval, que se aproxima da dissolução, é algo mesmo que está na base do desejo pelo Carnaval, e que também está na base das relações sociais construídas aqui no Brasil. Que não haja uma referência paterna simbólica, forte, entre nós, é um desejo 
com o qual convivemos em contextos os mais diversos possíveis, do trânsito ao serviço público.

Explico melhor: numa terra de gentes diversas, onde pelo menos três grandes referências simbólicas tiveram que conviver a cotoveladas e chicotadas - europeia, africana e indigena - parece faltar a cada uma, isoladamente, a força de unificação - Cf. Melman. Conviver numa sociedade um tanto "desorganizada", embora seja cansativo e meio absurdo, reflete um certo equilibrio de forças, permite entrever novas acomodaçôes...; o caso é que tanto o impulso de transformação, quanto as forças de repressão, aprenderam a agir nesse ambiente.

6.

O Carnaval atende largamente a esse desejo de dissolução, coloca sua chave simbólica na mão do rei Momo, uma autoridade que existe para subverter a ordem. Por outro lado, nesse mesmo impulso para destronar a autoridade e os laços constituídos, pode-se perceber um apelo não menos familiar na direção contrária: que haja referência simbólica dominante, que haja alguém forte o suficiente para colocar um limite nas coisas, para tomar as decisões por todos - mesmo que tendenciosamente.

O Carnaval alimentaria os dois impulsos simultaneamente: diversidade simbólica (que aponta para diversidade política) e controle autoritário. Nesse sentido, se enlaçaria com uma série de elementos da noção de baianidade?

7.

O fortalecimento e a potencialização das manifestações do Carnaval negro, em Salvador, coloca em movimento o próprio real, redimensionando o peso de uma das nossas referências simbólicas a partir da força de diversos coletivos, e abre espaço para sair do mero 
vai-e-vem desse tradicional carretel entre ordem estável e desordem momentânea.

PS1: Há muitos outros carnavais, inclusive o pós-moderno, isso aí é só um cordãozinho; texto escrito em 1996, antes do advento de muitas coisas, inclusive das celebridades. 


\section{De Caju em Caju... até a Cajuína}

Meu sobrinho americano chegou com um livrinho feito especialmente para viajantes, trazendo palavras importantes em português e sua "explicação" em inglês. Qual não foi minha surpresa ao consultar o verbete do caju: fruta típica que tem o sabor entre a pêra e o limão, com um rim grudado em cima...

Um rim? Quem no mundo poderia descrever um caju como algo meeiro entre pêra e limão, e ainda por cima achar que a castanha parece com um rim? Fiquei possesso. Mas agora, lendo o verbete "caju" do mestre Cascudo, descubro que a autoria dessa comparação esdrúxula (castanha com rim de ovelha) é de Georg Marcgrave ${ }^{1}$ (1610-1648).

Marcgrave era alemão, das redondezas de Dresden, e produziu um valioso compêndio sobre a riqueza natural do Brasil, com dedicatória a Mauricio de Nassau, e ainda hoje uma importante referência para a descrição dos peixes brasileiros a partir da nomenclatura indígena. Consta que Nassau era apaixonado por caju. Baixou decreto protegendo os cajueiros e fez com que o doce em compota chegasse às melhores mesas da Europa.

Pois, se uma opinião escalafobética emitida em 1638, e impressa dez anos depois, ainda retorna nos dias de hoje em manuais para viajantes ao Brasil, o que dizer de toda a tralha que nos descreve e nos deforma ao longo dos séculos - de De Gaulle ao trem pagador? 
Mas deixemos isso pra lá, pois essa não é uma crônica de apenas um caju. São vários. $\mathrm{O}$ nosso segundo caju está no próprio livro de Marcgrave, em sua belíssima ilustração-frontispício (que pode ser vista por inteiro em: http://research.amnh.org/ichthyology/neolit/ Marcgr/marcgrave1.html).

O ilustrador apresenta o Brasil como uma espécie de paraíso na Terra, onde a cornucópia da fartura jorra dos braços de sua divindade. Há um Adão e uma Eva indígenas postados de cada lado de um caminho de árvores frondosas. Índios dançando ao fundo, animais de todos os tipos. Mais acima, a presença da serpente confirma o cenário. E, certamente no lugar da maçã, do lado direito, um arbusto carregado de cajus.

Na composição imaginária dessa estampa, o caju assume o lugar do fruto proibido. Essa visão reverbera o papel da fruta como ícone do Brasil e da gente brasileira.

A época do caju coincide com o final do ano, e talvez seu gosto característico ajude a estabelecer uma marca no ciclo do tempo, tal como as nódoas que deixa nas roupas. $\mathrm{O}$ próprio Marcgrave anota o costume indígena de guardar as castanhas como registro da idade. Até hoje, no Nordeste, ainda é possível ouvir alguém dizer que tem "quarenta cajus". Mas trata-se de um tempo tropical, diga-se de passagem.

Transposto para o mundo das palavras, esse travo de caju acaba remetendo ao travo cristalino da Cajuína - e, no caso da canção de Caetano, à incrível rede de rimas que teria tudo pra ser exagero e até mau gosto (embora lembre a tradição repetitiva dos repentes), mas que bem ao contrário, soa contida e refinada. Um bom exercício de composição seria explicar como esse aparente excesso se transforma em gesto necessário, mais do que rima - sina.

destina / pequenina / sina / ilumina / nordestina / fina / retina / cajuína, cristalina, Teresina 
De onde se vê que a distância entre o caju e a metafísica é pouca - existirmos: a que será que se destina? - pergunta esse forró bissexto, cujo núcleo do traçado harmônico (a partir de rosa pequenina...) refaz em sequência, quase a totalidade da progressão fundamental, (i - I7 - iv - VII7 - III7 - VI - V - V7 - I7 - iv - V7 - i) em dó menor, remetendo tanto à tradição de um Luiz Gonzaga, como aos prelúdios de Bach, e aproveitando a riqueza do modo menor, cuja ambiguidade absorve a Tônica maior para seus propósitos.

Se do lado harmônico a inevitabilidade vem desse jogo barroco-nordestino de encadeamento em quintas, do lado melódico ela surge da estrita simetria construída com os desenhos de terça. Esquecendo a repetição das notas, cada verso reúne uma terça descendente e outra ascendente, e todos juntos funcionam como uma corrente de elos melódicos deslizando sobre a harmonia.

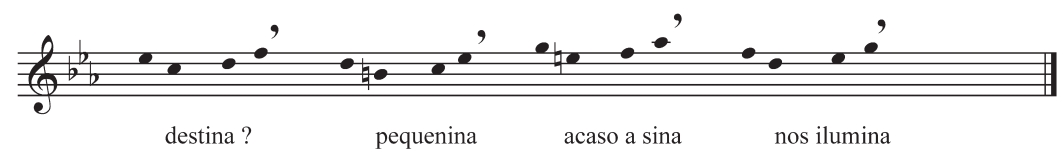

Eis aí minha sugestão auditiva de Ano Novo - veja e ouça Cajuína no SeuTubo (não estranhe, lembre do rim de ovelha) -, com atenção especial para o solo de violoncelo de Jacques Morelembaum. Ora, quem nunca percebeu? O violoncelo é uma espécie de caju de madeira, um instrumento tropical capaz de absorver todas as ressonâncias do mundo (assim, ajustamos as contas com Marcgrave).

O solo de violoncelo absorve a melancolia cristalina da canção e convoca acentos de vários cantos para celebrar um passeio sonoro que é ao mesmo tempo circunspecto e viajandão:

- a articulação do arco imita a moda sertaneja (como se fosse o movimento de pescoço da Almira de Jackson do Pandeiro), brinca 
com intervalos que remetem a um certo parentesco entre Nordeste e Oriente, acolhe ritmos do xaxado, evoca sequências em sétimas/sextas descendentes, desce até o dó grave (via réb trinado) e faz um arco de harmônicos sul ponticello, até que finalmente enuncia a melodia da canção, a qual continua o jogo...

Do fruto proibido ao violoncelo-caju, aprendemos que as questões humanas podem e devem ser enunciadas de qualquer ponto do planeta, especialmente de Teresina. Nunca cessaremos de nos traduzirmos uns aos outros, mesmo quando o tema é a intraduzibilidade da cultura ou da existência.

Na verdade, quanto ao caju, não precisa traduzir, basta morder.

${ }^{1}$ Embora seja de Thevet (1558) a mais antiga descrição do caju, que para ele se assemelhava a ovos de pata (pode?). 


\section{Acabou o papel!}

Quem foi que teve a "brilhante" ideia de rimar o título aí de cima com "jingle bells"? A resposta a essa pergunta abriria caminho para uma pequena história da esculhambação brasileira através da música. Que espécie de traço cultural seria a esculhambação?

Sobre a canção ando perguntando por aí, mas ninguém conseguiu me ajudar até o momento. Por exemplo: quando é que foi "composta" a versão mais brasileira das canções natalinas? Por quem? Se o leitor sabe, que me diga.

Certamente é anterior à década de 60 , porque na minha infância todos já a conheciam. E tem um sabor marcante de Rio de Janeiro - durante um certo tempo, cultivou-se no Rio a mania bizarra de fazer arruaça nas missas do galo.

A canção original (One horse open sleigh) é de autoria de James Lord Pierpont, e foi registrada em 1857, nos Estados Unidos. Trata-se de um Christmas carol feito curiosamente para o Dia de Ação de Graças. A letra original - ao contrário da versão oficial em português - não é nada espiritual ou carola, manda bater os sinos e rolar pela neve. A cinética da melodia alude justamente ao movimento do trenó, chegando mesmo a mencionar uma certa Senhorita Fanny Bright, que aparece para alegrar o passeio.

Antes mesmo de qualquer análise da esculhambação, vale a pena refazer o percurso mental da canção. Passar de "jingle bells" para "acabou o papel" é uma associação fantástica. Exibe o poder co- 
municativo dos grandes refrões. "Acabou o papel” é uma construção incrivelmente redonda e sonora. Além disso, é sutil, não entrega o jogo - já está sendo usada por ecologistas (confira na internet).

Somente na sequência é que o ouvinte vai perceber de que papel se trata. "Não faz mal, não faz mal, limpa com jornal". Novamente, uma clareza heráldica, apesar da implicação turva e grosseira! Esse joguinho safado de adiar a grosseria faz parte da estratégia composicional, assim como o contraste cativante do jogo de rimas "el, el, el" com "al, al, al”. Erudição pura.

Daí em diante surge nossa ancestral queixa sobre a carestia (o jornal tá caro - quem haveria de discordar?), e uma expressão popular envolvendo o chuchu, que não tinha nada a ver com a estória, mas estabelece as condições sonoras para o desfecho glorioso e indizível da última rima. Resumo da ópera: da brancura da neve ao cotidiano emporcalhado da evacuação.

Mas qual o sentido de avacalhar o Natal de jingle bells? Será que a versão teria surgido como uma reação ao desembarque maciço de "coisas americanas" a partir do pós-guerra, de Sinatra à coca-cola, constituindo dessa forma um gesto matreiro de resistência cultural? Seria, dessa forma, um manifesto contra a americanização do Natal?

Ou seria mais da ordem de uma tentativa de expurgar a inveja latente por que aqui não tem neve, trenó e desenvolvimento? Por se estar no excêntrico campo do outro - periférico? Afinal de contas, quando as pessoas cantam a versão apócrifa elas exibem um prazer todo especial, anunciando que o mundo está de cabeça pra baixo pelo menos o mundo do Papai Noel.

A pergunta vai permanecer no ar: será que a anarquia nos liberta, permitindo um espaço de identidade com uma certa autonomia, ou nos aprisiona nessa identidade pret-a-porter de brasilidade esculhambativa - que no mundo só tem paralelo mesmo na Austrália? 


\section{O Carnaval e a Infanta Mafalda}

Século XIII, Portugal: a infanta D. Mafalda deixa em testamento ao irmão D. Pedro o seu momum quadratum, sua máscara das farras do Momo. A coisa vem de longe, no caso, das mascaradas medievais.

Mas como tudo que se escarafuncha chega mesmo é na Grécia Antiga, lá está o nosso Momo, tido por Hesíodo como o filho da noite, rei do riso e do sarcasmo, cuja missão seria corrigir os homens e até os Deuses, pela troça e pela galhofa.

Em 1789, numa revolta de escravos na Bahia, a proposta de tratado de paz formulada pelos negros enunciava: "Poderemos brincar, folgar e cantar em todos os tempos que quisermos sem que nos impeça e nem seja preciso pedir licença” - nos lembra Jaime Sodré.

São raízes profundas. Que também podem ser exemplificadas pelo anti-carnaval, aquelas marchinhas que cantavam na televisão: "pipoca, meu bem, pipoca”, ou outra mais inspirada ainda: "como vai, como vai, como vai?", respondido pela pérola supimpa: "tudo bem, muito bem, bem, bem". Um verdadeiro ultraje ao pudor carnavalesco.

O Carnaval tem muito mais a ver com "se a canoa não virar, olê, olê, olá”, ou então com "vai ter que dar, vai ter que dar...”. Há aí uma dimensão imperativa evidente, que o Momo encarna com sua coroa, mas é um imperativo de gozo. 
Imperativo que se deixaria exemplificar por: "Ei, você aí, me dá um dinheiro aí, me dá um dinheiro aî"; ou então pela doce ambiguidade entre ordem e carinho no "venha cá, venha cá, venha cá...", ou no imperativo da sede, de água mineral: "tá com sede?" (Carlinhos Brown).

$\mathrm{Ou}$ ainda nos diversos comandos meio alucinados de segura aqui, agarra aqui, segura aqui, aqui, aqui e por aí vai (coisas do gênero). De forma mais elíptica (e elegante) na afirmação de que "atrás do trio elétrico só não vai quem já morreu", ou no "abre alas", que é praticamente um hino.

Explícito, mas com retórica elegante, em "vou beijar-te agora, não me leve a mal, hoje é Carnaval” (o imperativo transparece dessa necessidade de não ser levado a mal... imaginem, quem levaria?).

E não fica apenas no texto. A música também trabalha com imperativos. A tradicional "corre, corre, lambretinha" é um bom exemplo que sobrevive por tantas décadas, ou o dramático "Xô Satanás", de Durval Lélis, que progride da lentidão do alcoolismo ("eu era um bêbado...") até o delírio exorcista.

São músicas que criam dentro delas próprias, por causa da aceleração que provocam, uma analogia com a expectativa estrutural do Carnaval, a esperança de abolir limites, de virar outra coisa, algo que as máscaras, ou mesmo as muquiranas, ilustram muito bem.

Outra solução musical vem da construção de um conflito marcante entre trechos que estão 'no tempo' e outros em contratempo, como é o caso do frevo (Vassourinhas, por exemplo), ou usando esse conflito como microestrutura repetitiva, tal como na batucada. Quanta coisa da batucada veio diretamente do candomblé!

Mas, vejam bem, que alguém como Vadinho, o personagem inesquecível de Jorge Amado em Dona Flor..., que nos representa de maneira indiscutível como tipo cultural, morre numa das últimas 
requebradas em pleno Carnaval, e só aí começa sua sobrevida com Dona Flor.

É desse risco que nos fala o "se a canoa não virar", ou então o "eu vou beber, beber até cair"; há um Momo inofensivo, que pode ficar com a chave da cidade, e outro que nos lembra o filho da noite, o "medo de careta”, o "outro lado, do lado de lá do lado, que é lá do lado de lá".

A figura do Rei Momo acaba absorvendo essa série de ambiguidades produzidas por nossa sociedade com relação à figura paterna, e resvala fortemente para todos os campos da criação artística.

De certa forma, ele diz que a referência ordenadora não existe e isso dialoga com vários aspectos do nosso percurso histórico. Mas isso já é conversa para uma outra crônica... 


\section{Os pés no riacho ${ }^{1}$ \\ Rei como personagem cultural}

Roberto, oh Roberto, que estranha potência a vossa! Como te entender? E por que preciso?

Lá na década de 80, Regina Casé tinha um curioso bordão no revolucionário grupo Asdrúbal trouxe o trombone: 'Eu te amo, Roberto Carlos!' Isso era dito de forma tão escancarada que ficava óbvia a caricatura da melosidade platitudinosa (fascista?), a redundância da redundância transformada em atitude crítica e cômica - mas agora já faz 45 anos que cantei alegremente 'Calhambeque e que tudo mais vá pro inferno’ no recreio da minha escola primária, aprendendo a dedilhar meu primeiro mi menor, e vejo em pleno Maracanã milhares de pessoas ignorando a chuva por você, e seus cabelos longos permanecem (não sem algum esforço) quase do mesmo jeito, então, Roberto, buscar entendê-lo um pouco mais é buscar entender essa destemperada usina de imaginário chamada Brasil, mesmo contra minha desconfiança básica de canções melosas em quaternário (a voz flutuando em cima), com seu precioso quinhão para a homogeneização do que se ouve, do que se vende, afinal, há tantos outros compassos, uma canção em $7 / 8$ destruiria o amor?

Não, mas talvez perturbasse o riacho, aquele que Caetano usa em aliteração manhosa, para defini-lo: 'eu pus os meus pés no riacho, e acho que nunca os tirei', e que você próprio registra em 'Cachoeiro', com águas e mágoas do Itapemirim’, uma hermenêutica do riacho...! 
Qual não foi o espanto, em 1971, ao ouvir de sua boca a equação torta da ditadura plena ( 2 e 2 são 5 ), tudo ia mal, naquele dia o riacho correu ao contrário... direção que surpreendia e encantava, a sua voz em nome de uma visão crítica; mas ficou por ali.

Ao procurar seus próprios versos críticos, irônicos, rebeldes, conclamadores, nada muito consistente aparece (não vou considerar a fase da velocidade como rebeldia real)... mostrem-me um verso! Uma harmonia torta!

Mas não é justamente esse o beco sem saída da análise ${ }^{2}$ crítica de sua recepção!? Afastando-nos do que precisamos saber: notadamente, que personagem cultural é esse? Que espécie de côncavo constituímos como sociedade para o convexo de sua presença semi-secular? Por que não é possível aceitar que tudo seja simplesmente indústria, quantos passaram?

Roberto, oh Erasmo, que estranha potência a vossa! Estaria esse suposto vazio crítico diretamente associado à limpidez de uma certa representação da emoção, do amor, de um personagem ideal, depurado, sincero, confiável? Alguém que, de alguma forma, nos transmite uma sensação de continuidade de um Brasil-riacho?

E além disso, um personagem idealizado pela mulher: namorada (menina, linda); amante (Oh meu imenso amor, detalhes, vista a roupa meu bem, nunca mais te deixarei e tantas outras ); amiga (amiga) família (Primeira Dama / Tão linda, esperando neném...); mãe (Lady Laura); santa (Nossa Senhora)...

São tantas mulheres! Ou é apenas uma? Que esse personagem atende com seu perfil tão meigo e tão distinto daquele famoso estereótipo que Hollywood faz questão de projetar aqui - o macho latino, cubano, argentino, o tango. Seria Roberto, então, o bálsamo tão desejado dessa ferida?

Porque há certamente uma ferida, uma tristeza, um tom de choramingo que se faz charme, que atesta uma falta, e aí entra a mulher 
como personagem viva, e o homem como quem deseja estar ali também, como amante ideal.

Não é assim que começa 'Lady Laura'? Um filho que admite precisar do resgate da mãe $e^{3}$ - coisa rara quando já se é crescido e famoso. E pela mesma linha, Nossa Senhora, esse feito raríssimo de um cantor popular: inserir sua canção na liturgia católica... minha mãe adotava a canção como hino e como oração.

$\mathrm{O}$ artesanato da melodia contribui para a análise:

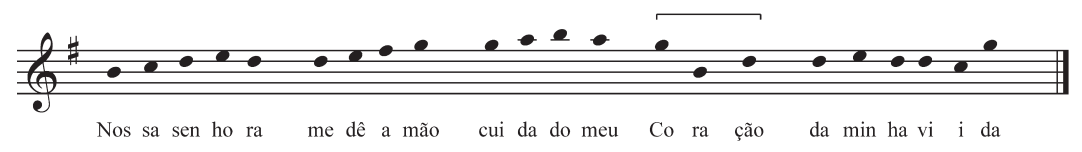

É muito difícil fazer coisas simples, quanto maior a simplicidade, maior a dificuldade. Esse gesto é um exemplo. Há uma subida íngreme do si inicial até sua oitava superior, e essa subida gera energia para a súplica - porém é a finalização do gesto que lhe dá originalidade, desfazendo tudo, ou confirmando tudo com a palavra 'Coração', que projeta um arpejo descendente de Sol. O coração arpejado dá conta da falta, é o reverso confirmador da agonia da subida.

Sem dúvida, Roberto é especial, inclusive porque teve que conviver com trauma e perda ainda na infância, em seu próprio corpo. Talvez essa pequena tragédia (o acidente de trem) tenha criado 'um' entre nós homens, que não se envergonha da falta, e assim pode reconhecer a mulher da forma que faz - para lá da simples imagem de galã.

Não há, porém, como isentar o personagem composicional de toda a cumplicidade com esse estado de comunicação sentimental e pouca invenção que predomina em nosso meio. Roberto, por favor, desafine! 
${ }^{1}$ Esta crônica foi escrita a pedido de Manuel Veiga.

${ }^{2}$ Vale conferir o livro do Pedro Alexandre Sanches, que inclusive observa a pouca produção analítica dedicada à obra de Roberto/Erasmo, ofuscada pelo lado mais crítico da MPB.

${ }^{3}$ Alguns anos antes, Lennon lançou 'Mother', mas a cena é bem outra: Mother, you had me! But I never had you! E que berros primais que o bezerro Lennon dá! 


\section{A música é uma causa}

Uma causa num tempo pós-causas? Que espécie de causa seria a música hoje no Brasil? Qual o jovem brasileiro que não tem (teve/ terá) uma banda? O que defende esse jovem com sua paixão sonora?

$\mathrm{O}$ que significa esse engajamento maciço ao mundo da música, ou deveria dizer, ao mundo das bandas? O IBGE deveria incluir a formação de bandas em seus questionários domiciliares, produzindo dessa forma o catálogo de todas as bandas brasileiras? Maneiro.

Para onde vão as bandas brasileiras? Apontam para uma sociedade mais saudável, uma grande tribo-fábrica de sonoridades e sociabilidades, ou para mais do mesmo? Aliás, essas bandas todas que existem passam pelas escolas? Evidente que não. Não existe ensino formal sistemático de música no País, e bem que deveria haver.

Para onde vai a música? Mas não existe uma música só. Então para onde vão todas elas? Só assim vou poder opinar melhor sobre sua condição de ser causa ou consequência. Ou será que já existem causas estáticas, causas que não vão a lugar nenhum? Pós-causas? O que é mesmo uma causa? Hoje.

Ouço a música dos esquimós (Inuit) raspando a garganta em jogos rítmicos bem modernos aos nossos ouvidos, a música dos índios brasileiros, dos pigmeus, dos aborígenes australianos. São causas? São música, perguntam alguns? Estão desaparecendo mais rápido que as florestas. A grande causa é a preservação. 
Quem cuida do planejamento das músicas brasileiras? Além de Faustão? Quando teremos uma outra realidade para a distribuição de conteúdos, sem esse absurdo cabo-de-guerra entre donos da comunicação, que se ramifica em trincheiras territoriais do grotão até a metrópole?

De tantas e tantas questôes e situações convocadas pela pergunta "para onde vai a música brasileira?" - sendo a defesa da música brasileira uma causa e tanto -, escolho fazer um recorte sobre esse mundo das bandas, dos jovens, da necessidade de projetar, recriar, copiar, ou mesmo inventar identidades. Da candura desses jovens criadores e intérpretes. De seu enorme potencial, e inconsciência.

A curtição tão intensa da música certamente tem a ver com o prazer que ela proporciona, mas esse prazer também está ligado à possibilidade de ficar rico e famoso - "se a banda bombar!". No Brasil, a música (e o futebol) são canais "democráticos" para a roleta da fama. Ao contrário do lucro, ninguém sabe ao certo de onde vai vir o sucesso. Talvez seja eu!

Aliás, como é que funciona o prazer da música? Onde se aprende sobre isso? Existe prazer na música fora da fama e da mídia, mesmo que imaginadas, antecipadas?

Ao que tudo indica, a realidade psicológica da fama é semelhante à ingestão de uma droga estimulante e potencializadora do ego. Isso aí pode ser um processo saudável de construção de identidade, de projeção de uma marca, ou pode ser o simples macaqueamento de um estilo vendável. A distinção é a qualidade. Ou seja: além da preservação existe a busca de qualidade. Que espécie de causa é a busca de qualidade musical?

A música também toca na produção de substâncias estimulantes e potencializadoras do ego, a música pode envolver mergulhos no tecido sonoro, na viagem musical. Nunca a oferta de música foi tão ampla, fugindo inclusive ao controle do esquema. Nunca a curtição 
foi tanta. Mas nunca essa ambição de fama e dinheiro foi tão potente e instrumentalizadora com relação à música.

O resultado desse dilema é um cenário complexo de oportunidades e de travações. Um cenário onde o iniciante se relaciona com a mídia e com o seu agrupamento mais próximo. Um cenário onde a possibilidade de desenvolvimento de crítica e de criatividade se esvai, já que os indicadores de qualidade estão todos atrelados ao grau de consumo.

Como é que esse universo de gente e de sons tão diversos pode ser estimulado a caminhar para um nível de felicidade mais maduro e sensato? Um patamar de existência onde os sons, suas causas, suas questões, viagem sem tanto apego ao imaginário predatório dos nossos dias? 


\section{Debaixo do barro do chão}

Silêncio. Há uma zabumba pensando. Pensando? O que porventura pensam as zabumbas entre uma batida e outra, entre um tempo e um contratempo? Tum... tum. Entre a afirmação de uma ordem hegemônica (de tempos) e sua imediata desautorização pelo ataque no finalzinho do período regulamentar, fazendo um contratempo desabusado, audacioso, que quase rouba para si o status de tempo forte, quando é mera dissonância rítmica. Será?

Não sei se o leitor entende de dissonâncias, acordes dissonantes, etc. Aqui faço referência a dissonâncias rítmicas, como se fosse possível transpor o conceito do campo das alturas para o campo das durações. A mais curiosa das dissonâncias rítmicas seria a hemíola, uma ordem rítmica que surge como contravenção e ameaça se tornar dominante...

A célula rítmica característica do forró afirma um tempo forte e logo o desautoriza, para em seguida reafirmá-lo... fica brincando de esconde-esconde com o tempo forte, daí o colorido todo da coisa, e o cenário adequado para um vozeirão manhoso que nem o de Luiz Gonzaga.

Os meus pés não precisam refletir sobre o assunto. São imediatamente convocados para um xaxado imaginário - xote, baião, congado, corta-jaca, maracatu, frevo, samba e que mais? Há quem diga que os pés pensam antes da cabeça. São os motores da identidade. Pe-dagogia. 
O verdadeiro desafio educacional é descobrir em que direção caminhar - e os pés parecem saber isso antes. Será que foram as zabumbas que inventaram o Nordeste? Como se fossem zabumbas-galo tecendo manhãs em cada noite de forró? Como se, no amálgama de tempo e contratempo, estivéssemos representando essa tensão permanente entre a obsessão do enraizamento e a condição inequívoca de desterro que nos constitui como Brasil brasileiro? Tensão essa, cada vez mais característica de uma época pós, da qual talvez sejamos laboratório ímpar?

O enraizamento e o desenraizamento formam um contínuo. A desterritorialização pode ser um grande feito de identidade. Construir uma literatura/música sem marcas de lugar algum. Libertar-se da indexação imaginária pela via do local. Clarice Lispector?

O Nordeste não existe porque o Brasil não existe (nunca existiu, já não existe)? Ou talvez porque tenha inventado o Brasil através da zabumba?

Calma aí. O que está sendo dito é que a construção da ideia de Brasil é também uma construção nordestina. E olhe que nunca me senti nordestino. Até os 15 anos a minha geografia apresentava a Bahia como região leste - junto com Minas, Rio, Espírito Santo e Sergipe.

Ou porque é mais um efeito conjuntural do último século (surgiu junto com a Sudene! em 1969/70), ou seja, depois que a relativa equanimidade entre províncias de um mesmo império tropical cedeu lugar à concentração de poder no centro-sul?

Estou lembrando que o conceito de Nordeste era absolutamente desnecessário na época do Império. Existiam a Corte e as províncias.

Não sei se existe Nordeste, mas a zabumba existe. E com ela, esse apelo irresistível ao xaxado. Mas que xaxado seria esse? O que deveríamos dançar? 
Como tecer novas manhãs, com galos e zabumbas cantando aqui e alhures - no mundo todo haverá nordestes e mais nordestes? Como trabalhar por manhãs intersubjetivas e interinstitucionais? (Rede)

Como permitir que tantas vozes e tantos pés invisíveis encontrem suporte nessas levadas de zabumba? (Identidade)

Como articular a cumplicidade necessária para que um lugar-de-fala seja ao mesmo tempo lugar de libertação e de futuro, lugar-múltiplo, zabumba-sanfona e pífano (Nordeste)?

"Há de haver pelo menos por ali, os pássaros que nós idealizamos" ${ }^{1}$ dizia o poeta nordestino.

'Jorge de Lima, Invenção de Orfeu XXVI 


\section{Tudo azul}

"A vida é uma retifica, da ignorância até a sabedoria. Mas depois virá a vivência, e aí, o homem se tornará divino. Sim, também os deuses morrem." Walter Smetak

- Tudo bem?

- Tudo azul: escrevo com lápis azul num céu azul...

- Deu de lembrar, Smetak ${ }^{1}$

- Eu aprecio esse choque interno entre lógica e absurdo, uma ação tão grandiosa como escrever de lápis no céu, sem deixar qualquer registro...

- E, além disso, quem não gostaria de possuir um lápis de escrever celeste? Seria um sonho fantástico, abrir a janela e escrever no horizonte...

- Obviamente há uma grandiosidade que enfrenta o divino, o céu sempre foi um lugar que a ancestralidade reservou aos deuses.

- É, mas curiosamente esse desafio aos deuses coincide também com um gesto de desconstrução do poder do autor/compositor, aquele que escreve, porém, nada... escreve nada. Só faz quando desfaz. 
- É verdade, uma espécie de auto-ironia desconstrutiva, algo que a expressão inicial destila e anuncia - 'tudo azul'. Como poderia estar tudo azul? Mas na verdade, está, o lápis é azul e o céu também.

- O sonho de onipotência humana anulado pela invisibilidade do ato. Não haveria aí uma certa culpa, bastante ocidental diga-se de passagem, contrastando com o azul cosmológico e imutável? Uma consciência de que os feitos humanos são fúteis e perigosos.

- Estamos lidando com a representação do apagamento de todas as marcas possíveis, não existem marcas, só o azul... Não existe Europa, filosofia, ciência ou artes, apenas o azul.

- Uma crítica do sonho ou sintoma de reencontrar a plenitude perdida através da elaboração de marcas, deixadas em cavernas ontem, na internet hoje. A plenitude seria o azul.

- São muitos conteúdos e universos que se encontram nessa imagem.

- Dá para lembrar de Fernando Pessoa (o conflito entre os seus heterônimos Alberto Caieiro e Álvaro de Campos), de Charles Ives com sua 'Pergunta não respondida' (ou irrespondível).

- Por outro lado, o que foi escrito, foi escrito. Existe algo que foi escrito, queira o mundo (destino, oriente, deuses) ou não. Está na memória motora de quem escreveu.

- Você está dizendo que, ao mesmo tempo, desafiando lógica-destino-mundo, essa imagem preserva o ato de criação, em sua invisibilidade?

- Pois é, precisamos discutir melhor essa invisibilidade, pois ela parece ser o significante central da imagem. Afinal de contas, existe uma diferença entre invisível e irreal. O que é invisível também existe, pode fazer parte da realidade psíquica e da realidade externa.

- Por outro ângulo, trata-se de uma invisibilidade bastante atual face à idiotização do mundo... pela via da aceleração do capitalismo, do poder instrumentalizador. As marcas inúteis ou simplesmente interessadas (em algo) se multiplicam e se inflacionam. Onde estariam as mensagens azuis escritas em fundo azul? 
- Esse será o papel do artista sério? (Smetak usava esse adjetivo com seriedade). Ou talvez apenas os indígenas imaculados pela civilização sejam capazes de conceber esse azul celeste?

- Você pensa que o mundo pós-utopia é um mundo idiotizado? Ou seriam as utopias elas próprias entraves, que agora podemos imaginar ultrapassar?

- A ideia de ultrapassar algo não combina com o mundo azul da imagem. Não se pode ultrapassar o azul. Ele é o inultrapassável.

- Tudo bem?

- Tudo azul, mas como é que a gente sacode a poeira desse astral?

- Vamo lá:

Foi um dia um homem que foi caçar e pegou um bicho preto feito um urubu. Era o cão que estava fazendo penitência. O homem levou o bicho para casa e comeu. De noite o bicho começou a gritar na barriga do homem: Corró, corró, por onde eu saio? Saia pela boca. Corró, corró, tua boca é podre. Saia pelo ouvido. Saia pelo nariz. Saia pelo chicote. Seu chicote é sujo. Saia pelo umbigo. O bicho deu um estouro danado e o homem esticou a canela. ('O homem que comeu o diabo', contada por Wanderlina a Hildegardes Vianna, em 1950, na Bahia)

PS. Smetak e Hildegardes foram colegas de escola durante muitos anos. Porém, creio que pouco conversaram durante esse tempo.

${ }^{1}$ Trata-se de um título de Walter Smetak (1913-1984) para um artigo publicado na revista ART (editado por mim). Smetak foi membro emérito do Grupo de Compositores da Bahia. 


\section{Em busca de uma "razão composicional” I}

Onde começa a prática criativa e composicional?

Parto da constatação, um tanto óbvia, de que para o compositor, quando se põe a compor, falta música no mundo... De forma mais precisa, falta aquela música que está a imaginar, ou que está apenas coçando; as músicas tem um estágio em que são coceiras; daí pode ser que passe e nenhuma música precise nascer; do contrário nasce a música e morre a coceira...

...morre é maneira de falar, se transforma; donde, vivemos num mundo de coceiras sonoras; de Bach, de Debussy, de Caymmi... Coceiras que os intérpretes têm que reaprender a coçar; e sutilmente vão introduzindo as suas próprias por entre dedilhados e articulações... e que os ouvintes também adotam como suas. Tudo é coceira, digo, semiose.

De todas as acepções da palavra prática - uso, hábito, rotina, exercício, aplicação de teoria -, a mais poética e a mais interessante é uma das últimas listadas no dicionário: licença concedida a navegantes para comunicarem com um porto ou uma cidade. A prática da invenção é uma navegação. Mesmo quando se trata de identidades, ou melhor, especialmente quando se trata de identidades... Se insistirmos além da conta na visão de prática como aplicação da teoria, perderemos de vista a capacidade surpreendente que a prática exerce de instigar novas teorias. 
Além de ser acepção, a navegação é uma excelente metáfora: ninguém navega sem alguma experiência prévia de flutuação; experiência prévia que bem pode receber a alcunha de teoria da navegação; que bem pode ser o conhecimento da técnica de construção de jangadas, um modelo descritivo do comportamento dos astros, marés etc...; ou simplesmente a convicção de que se deseja ir a algum lugar (saindo de outro), algo que é tão imprescindível para a teoria quanto para a navegação.

Logo em seguida a esse cenário surge um nível mais antecedente, envolvendo o desejo de navegar - matriz tanto da teoria quanto da prática. O desejo reúne as duas dimensões num todo mais amplo, que pode beirar a necessidade ontológica: "navegar é preciso...". Para dar conta da invenção, não podemos escapulir do nível do desejo, do nível da construção de significações...

Mas, ao concluir uma viagem, analisando-se os diários de bordo, descobre-se que a necessidade de desviar de um iceberg - ou seja, a decisão de operar esse desvio -, ou o envolvimento numa perseguição de caça a algumas baleias que apareceram no caminho, ou mesmo aqueles mergulhos eróticos na costa de uma ilha paradisíaca... nada disso estava presente em quadro teórico algum, e, no entanto, aconteceram, precisaram acontecer. Em retrospecto, um analista conseguirá interpretar tais decisões como elementos recuperados de uma teoria que só permite visualização a posteriori.

$\mathrm{O}$ ato de compor (o ato de inventar) encerra um diálogo entre teoria e prática composicional. Se uma composição fosse totalmente definida por alguma teoria prévia, então, o único sentido da análise (da audição, da interpretação e do ensino...) seria a conexão com essa Ur-Theorie. A possibilidade de múltiplas leituras é a marca da abertura de significação, da friç̧ão criativa entre prática e teoria, entre autores e leitores, entre textos e contextos. Talvez possa se dizer que 
uma prática composicional nasce de alguma teoria composicional (explícita ou não), mas, também gera outras tantas.

"Como se chama aquela flor que voa de pássaro em pássaro?" (Pablo Neruda)

Essa abertura para a significação parece ser uma das características marcantes da invenção artística. É talvez o que leva Neruda a construir esse verso curioso. A ideia absurda faz todo sentido no verso. A lógica da criação, e especialmente da música, depende mais da imprevisibilidade do que do caminho linear e tradicional da lógica discursiva - se M é P, algum S é M, então?

A significação musical depende, para existir, do conflito implícito entre aquilo que é ouvido, e aquilo que está sendo contradito pelo que se ouve; em outras palavras, da tensão entre o que o compositor (ou agente da criação) faz, e aquilo que fez o ouvinte imaginar que faria.

Por mais interessante que tudo isso seja, o que desejamos focar no momento é a configuração daquilo que poderíamos denominar, com toda cautela, de razão composicional - uma instância que abrange teoria e prática, e que responde pela realização das escolhas e pela cristalização de critérios. Não se trata de terreno muito ameno. O conceito de razão não é nada simplório no pensamento ocidental.

Falar numa razão composicional não significa ser cooptado pela incandescência do conceito originário, cujo núcleo central seria a acepção de razão como guia da conduta humana no mundo. Pelo contrário, essa escolha significa o estabelecimento de um diálogo e de uma ressignificação, que por sinal, não acontecem sobre algo estável e perene. O conceito de razão tem sido o lugar de muitas mudanças e de reviravoltas do pensamento. Talvez seja um caminho... 


\section{Aos Mestres com Carinho}

Olha quanta África existe no Brasil! E quanto aprendemos com essas pessoas que de lá vieram. Gente que nos civilizou - pela ética e pela estética. Quem já comeu um acarajé sabe que não é apenas questão de temperos, é questão de mentalidade. Costumo dizer que os ritmos africanos são acarajés sonoros. Existe alguma coisa sonora deste país que não precise agradecer e reverenciar tal ancestralidade? E existe Brasil sem música? Da bossa nova ao baião, do frevo ao reggae, do nacionalismo ao tropicalismo e até mesmo ao serialismo, do maracatu ao samba, e haja samba - batuque, pagode, samba-de-roda, chula, partido-alto, fobó, umbigada, arrasta-pé, balança-flandre, forrobodó, fungangá e por aí vai. Mas de onde vem tanta sabedoria rítmica?

Essa crônica musical é uma homenagem ao Mestre Erenilton Bispo dos Santos, um dos mais antigos alabês da Bahia (ainda na ativa), que vive 24 horas do dia no mundo da música afro-brasileira, e que será homenageado durante o VII Mercado Cultural, no início de dezembro, pelo grupo Ilê Fun-Fun de Edvaldo Araújo, outro peso pesado do panteão rítmico baiano. Precisamos conhecer de perto essa gente. Se quase tudo que ouvimos veio, de uma forma ou de outra, desse mesmo manancial, por que não interagir diretamente com a fonte original?

O universo da música afro-brasileira é um universo cativante, cheio de vivacidade. Quem conhece o toque do Ijexá sabe do que 
estou falando. O ritmo africano é filho de uma mentalidade outra - a mesma do acarajé. Longe da obsessão ocidental pela linearidade, a rítmica africana flutua em ciclos de equilíbrio e desequilíbrio, convocando o corpo a participar da fruição de uma presença, seja em mergulho de consciência alterada, ou em simples rebolados de natureza diversa. A metafísica que espere.

Os alabês são mesmo os "bam-bam-bans" da música religiosa afro-brasileira. Do alto de sua sabedoria e tendo à frente o maior dos três atabaques (o Rum), eles coordenam a execução musical das festas e solenidades, reverenciando os orixás com os toques e os cânticos apropriados. É um aprendizado de vida. Aprender um desses ritmos já é difícil, imagine aprender todo um repertório de toques e de canções? O saber de cada um deles é enorme. E não é só saber musical. É saber de vida, a música vem junto com os valores adquiridos, especialmente o respeito pela própria tradição, pelos mais velhos, pela natureza...

Erenilton é oriundo de uma das casas mais tradicionais da Bahia - o Terreiro de Oxumaré, na Vasco da Gama. Reverencia as canções e os ritmos de origem africana, ensina aos mais jovens, e agita no mundo do Carnaval. Atuou durante muitos anos como compositor e diretor nos "Filhos de Gandhi", e agora dirige com todo carinho e dedicação o Afoxé "Filhos de Korin Efan", que tem sede no Centro Histórico, Ladeira do Paço n. 26. Dessa forma, dignifica tanto o âmbito da tradição, como o da invenção.

Nasceu em 1943, no bairro Fazenda Garcia. Quem primeiro contribuiu para seu aprendizado foi sua mãe, Dona Simpliciana Brasília da Encarnação: "Ela era de Ogum. Esse Ogum quando chegava, cantava muito, e aí eu ficava escutando, era menino de nove anos... Eu me dediquei a aprender e aprendi algumas coisas com ele..., recorda o Mestre.

A conversa com Erenilton corre fácil. A gente vai percebendo que é toda uma história da cidade de Salvador que vai sendo contada 
em sua trajetória. Lembra que ainda criança, na hora de começar a festa no candomblé, o Juizado de Menores exigia que todos os jovens saíssem do barracão - para a mentalidade preconceituosa da época, o candomblé era contravenção, tinha que registrar em delegacia especializada. Mas Erenilton não ia ser logrado por essa turma, se escondia embaixo das saias rodadas de alguma das filhas da casa e assistia tudo dali, quietinho. E assim foi aprendendo o que sabe hoje...

E que riqueza de lembranças quando fala de seus próprios mestres: "O pessoal gostava de mim. Não podia fazer malcriação, porque se a pessoa fizesse malcriação, o mestre jogava a agente pra fora, e não ensinava nada. A gente tinha que ter a língua muito presa. Não podia falar nada. A gente tinha que aprender uma coisa aqui, e guardar". Tinha o Manuel Alabê e o Januário, ambos do próprio Terreiro Oxumaré. Aliás, foi o finado Manuel Alabê que deu aquele empurrão necessário para o jovem investir nessa direção: "Você tem que aprender, para servir pra você e pra sua mãe”. E tinha também Alcênio, figura reverenciada ao máximo por Erenilton, que quando ouvia seu toque, pensava: "um dia ainda vou aprender a tocar esse Rum".

Mas o jovem Erenilton foi crescendo e estabelecendo contato com outros centros de excelência em música afro-brasileira, os Terreiros da Casa Branca e do Gantois. Do primeiro lembra da importante presença do Mestre Cipriano, com quem aprendeu muitos segredos e canções, e do Ogã Antonio Manuel Bonfim. Do Gantois, casa da reverenciada Ialorixá Mãe Menininha, lembra do Mestre Vadinho-boca-de-ferramenta, professor de várias gerações de músicos, inclusive do percussionista Gabi Guedes, que transitou para o cenário da música popular, tocando hoje na banda de Jimmy Cliff.

Agora, aos sessenta e poucos anos, e já como tema de uma tese de doutorado na área de percussão, Erenilton está envolvido com a gravação de três CDs, inclusive com músicas do candomblé. Desco- 
briu que precisa registrar o que sabe, deixando para as gerações mais novas.

Viva o Mestre Erenilton Bispo dos Santos, e todos os mestres populares da cultura brasileira, embaixadores culturais daquilo que fomos, daquilo que somos e, especialmente, daquilo que poderemos vir a ser. 


\section{Apesar de você \\ a música e a ditadura}

Hoje você é quem manda, falou tá falado, não tem discussão...

Chico Buarque

Estamos acostumados a falar de educação como construção positiva que se afasta da ignorância. $\mathrm{O}$ fenômeno ditadura nos obriga a pensar em seu reverso, a deseducação, que se apoia no processo de cerceamento da discussão, e consequentemente, da eliminação sistemática das diferenças. Ora, a liberdade de discutir afeta não apenas o rumo das decisões das questões colocadas em evidência: afeta também a própria construção da agenda. Vale lembrar que democracia é, antes de tudo, o poder de escolher o que escolher - ao invés de escolher o vencedor do Big Brother, escolher se vai haver ou não esse tipo de programa, se as emissoras vão ter ou não programação local, que tipo de políticas culturais serão implementadas, e assim por diante.

A vida cultural de uma sociedade é profundamente afetada pelo grau de liberdade de relacionamento com as manifestações artísticas e com os processos comunicativos. Já se vê que não estamos tratando ditadura e democracia como dois estados fixos e opostos (tipo liga/ desliga), e sim pensando num continuum de gradações de liberdade, e de educação para usufruí-la. Sendo assim, é importante reconhecer que os problemas engendrados pela ditadura de 64 não evaporaram 
com as diretas: eles estão engatados a situações estruturais da sociedade brasileira, aferrados a rincões os mais diversos e poderiam ser discutidos no contexto atual, ou ainda de forma histórica, ao longo do século XX.

Embora tenha sido heróico o esforço de burlar as censuras e esculpir mensagens e, mais que isso, esculpir uma visão de futuro, uma visão de solidariedade para além da repressão e da violência, tal como a pérola de Chico Buarque fez - canções sem as quais seria muito mais difícil atravessar de um lado para o outro -, e apesar de esse ser o lado mais visível e poético da questão, é preciso estar atento para uma outra dimensão: a violência que foi cristalizada na construção de estilos comunicativos que reverberavam o autoritarismo e o des-incentivo para pensar e escolher.

Estamos falando da montagem de uma gigantesca rede televisiva, e mais além, da montagem de um estilo de comunicação. Estamos falando do poder que esse estilo de comunicação teve sobre a formação dos públicos e sobre as bases da indústria cultural que, de uma forma ou de outra, representa o que aí está até os nossos dias. Estamos falando de décadas em que a "realidade nacional" era revelada diariamente de forma uniformizada para todas as regiões e quase todas as camadas da população - sendo a atual figura um tanto embalsamada do apresentador oficial, o ícone desse definhamento. Ou ainda, da alternativa perversa, bem exemplificada pela Porta da Esperança, ratoeira dos necessitados e carentes brasileiros, onde a exclusão ganhava ares de espetacularidade, entremeando lágrimas, humilhações, êxitos milagrosos, bondade do empresariado paulista, etc.

São apenas dois ícones, porém imaginem sua multiplicação; e imaginem o impacto de tudo isso sobre a formação de produtos culturais, e sobre os critérios para escolher o que ouvir e a que universo musical pertencer - serve como exemplo do processo, no fim da linha, o fato de que muitos índios Waiãpi esqueceram suas canções, 
colocando no lugar delas o repertório do Rei, com posters pendurados por toda a tribo. Para complicar, os processos de globalização (mais recentes) se encarregaram de levar adiante a fragilidade que já estava plantada. Tudo isso configura o legado mais preocupante de 64, e é através de seu entendimento que poderíamos ter acesso ao verdadeiro paradoxo cultural com o qual se defronta a sociedade brasileira de hoje.

Somos uma potência mundial em termos de diversidade cultural (tanto quanto em biodiversidade) - e o Nordeste é o grande celeiro, o Amazonas cultural. O nosso povo tem uma herança auditiva impressionante, uma maturidade rítmica que consegue lidar com sutilezas recônditas da construção musical. Essa riqueza ancestral explode em manifestações absolutamente cativantes e tem gerado desenvolvimentos capazes de projetar globalmente nossos valores por exemplo, através do samba e da bossa nova, ou através de Villa-Lobos, no campo erudito.

Apesar de tudo isso, somos um grande mercado para o lixo cultural sonoro, promovemos nulidades nacionais e internacionais, deseducamos através da música e atuamos de forma a destruir essa memória fabulosa, impedindo que desemperrem as engrenagens em favor de um florescimento cultural orgânico e diferenciado. Nossa estrutura de educação para a cultura musical é uma piada, é absolutamente colada na mídia, não há mensagens alternativas sendo veiculadas de forma sistemática pela rede educacional. Poderia ser diferente? Seria possível investir pesadamente em deseducação e colher do outro lado 'flores amorosas'?

O fato é que somos um arsenal de criatividade à espera de um processo eficaz de ignição (algo que o MINC estabelece com todas as letras em documento recente sobre cultura e desenvolvimento), com um impacto potencial enorme sobre a sociedade como um todo, sua capacidade de produzir divisas - via turismo, via exportação de pro- 
dutos culturais, via construção de valor agregado para produtos de toda espécie, via potencialização de ONGs e redes sociais, etc.

Sendo assim, mais importante que celebrar o que acabou (mas nem tanto), é necessário refletir sobre o seu legado e suas transmutações, e sobre as sombras que projetam na área da cultura - o que significa lutar pela celebração da diversidade (e contra a homogeneização de produtos e de mercados), pela construção de diálogos entre passado e futuro, entre o local e o mundial, entre tradições e perspectivas eruditas e populares ('erupodiputolização', dizem jocosamente meus alunos de composição), e, sobretudo, pela implantação de políticas que compensem tantos e tantos anos de deseducação. Enquanto isso, parece legítimo continuar cantando: 'Apesar de você, amanhã há de ser, outro dia.... . 


\section{A hora e a vez da 'erupodiputolização'}

É verdade que tem "puto" aí pelo meio do nome, mas, em princípio, nada a ver com molecagem ou coisa do gênero. Trata-se de assunto sério, inclusive tema de elucubrações diversas em música e adjacências.

O palavrão nada mais é do que o cruzamento de dois outros - erudito e popular -, basta ir alternando as sílabas para entender como um se enrosca no outro. Portanto, filho de duas ficções.

Dito isso, ou seja, que todos os gatos são pardos, vale lembrar que o Brasil sempre foi o lugar de putolizações as mais diversas (agora estou usando a forma carinhosa e diminutiva).

$\mathrm{O}$ assunto é tão vasto que ameaça estragar qualquer plano de coerência do cronista, putolizado ou não - tá vendo, já se infiltrou no próprio estilo desta singela comunicação.

Está na hora de explicar com exemplos. Lembram daquelas sonoridades maravilhosas no arranjo de Construção de Chico Buarque? Pois foi o ouvido transgressor/erudito de Rogério Duprat que as concebeu. $\mathrm{E}$ a investida de Villa-Lobos em canções e ritmos da terra? Ou ainda, a aproximação recente entre Caetano e Jaquinho Morelembaum em torno da orquestração de suas canções?

Não gosto de dizer que o Brasil é o país das misturas de gêneros e de estilos. Porque a própria ideia de mistura remete a uma perda de 
identidade, uma confusão que embaralha as distinções. Prefiro pensar em encontros, por mais improváveis que sejam.

O frevo, por exemplo. Quem poderia prever que os salóes da Europa se abririam para um gênero rural como a polca, que essa polca já estilizada (eruditizada) seria introduzida em 1853, no Rio de Janeiro, e daí para Recife, onde a utilização por bandas militares com a presença de capoeiristas levaria às últimas consequências. Uma viagem e tanto, colocando a periferia da Europa em contato com a nossa.

Não muda muito quando o assunto é bossa nova. Se de um lado tem a herança da rítmica afro-brasileira, por outro, o que seria da bossa sem aquelas harmonias de fim-de-século que entortam os dedos de qualquer violonista? No mínimo o acorde precisa ser de sétima maior.

Então, não faz muito sentido classificar a audição de uma obra como "A Truta", de Schubert, que se baseia numa canção popular europeia, como experiência erudita; e a audição de "Desafinado", na voz de João Gilberto, uma canção que brinca com um curioso entortamento da tonalidade, como coisa popular.

Em rápidas pinceladas - frevo, samba, bossa nova, forró, tropicália, axé: todos esses gêneros ou repertórios foram palco de interações as mais diversas, as mais curiosas.

Outras tantas e tantas aventuras podem ser contadas pelo viés da tradição de concerto. Os vanguardistas brasileiros precisaram resistir à pressão de purismo do movimento internacional, pois tinham consciência da importância do diálogo com tudo que foi preservado e transformado nos grotões do País. Exemplos não faltam: Guerra-Peixe no Rio (e Recife), Lindembergue Cardoso na Bahia, Gilberto Mendes em Santos. Todos desenvolveram experimentos musicais em torno do encontro improvável entre coisas de lá, daqui e de acolá.

Por isso, parece muito abestalhado qualquer discurso que pretenda entronizar falsos purismos. Parece ridículo ir a concertos 
como forma de apego a um signo de distinção e finura. A Orquestra Sinfônica não é a "maior" criação cultural da humanidade. Como diz Juarez Paraíso, a maior criação cultural da humanidade é Deus.

Do lado da indústria cultural, a produção popular enfrenta o desafio do enlatado internacional. A regressão para bobageiras locais tem mostrado ser eficaz em certa medida, garantindo mercados. Mas qual o futuro desse impasse?

Creio que o futuro da música no Brasil - e, aliás, o seu presente também - depende, em boa medida, da capacidade que tenhamos, como sociedade, de permitir que essas negociações continuem fluindo. Para dizer com humor, precisamos radicalizar a erupodiputolização, multiplicando os encontros condignos.

Gostaria de ouvir depois de um concerto para violino e orquestra, a maravilhosa música dos índios Timbira, por que não? Depois de uma peça eletrônica de Rodolfo Caesar, o cântico do caboclo Sultão das Matas. Depois de um quarteto de Schubert, o de Eli-Eri.

O que nos fez forte em termos de música foi justamente a possibilidade ampliada desses encontros improváveis. Não imagino de outra forma um esforço de educação musical em nível nacional.

Nada disso é fácil, porém. Ah! Como são em geral horríveis os arranjos de música popular para Orquestra Sinfônica, vazios e insossos. Ah! Como tantas vezes são absolutamente desajeitados os compositores eruditos que botam uns ritmozinhos picantes em suas imitações sinfônicas. Ah! Quem vai convencer o solista que Beethoven já morreu, e quem gosta de mim sou eu?

PS. Apesar de tudo que foi dito, vale lembrar: existem sim misturas intragáveis e muito cambalacho disfarçado de abertura de espírito. Não se esqueçam de denunciar ao Procon. 


\section{Caso de orquestra um espirro em Mozart}

Poucas aberturas têm ideias melódicas tão felizes e vibrantes como 'As Bodas de Figaro' de Mozart. Agilidade e simetria apresentadas por um desenho que todas as cordas executam em semicolcheias, ornamentando o acorde a tonalidade da obra: Ré Maior. Tudo com uma lógica de discurso impecável - não dá para tirar uma nota, parece Caymmi.

De repente, um espirro. Isso mesmo, uma fatalidade, alguém espirrou bem na hora da breve pausa entre uma frase e outra. Os músicos, mesmo ocupados em executar dedilhados e arcadas precisas, se entreolharam para descobrir de onde havia partido o ruído intruso.

Vinha do lado dos segundos violinos, aquela seção que fica à esquerda do spalla, o violino principal, e ao mirar o maestro com o canto do olho - arte que define um bom músico de orquestra -, todos perceberam que as bochechas tremelicantes do famoso regente estavam mais tremelicantes que nunca.

Poderia aqui abrir parênteses para instituir um concurso de adivinhação - qual o maestro brasileiro de bochechas mais tremelicantes? - e teríamos que discutir e entender a função e os diversos tipos de estertores expressivos dos titulares da batuta, que vão desde os meneios de cabeça, os ricolchetes de cabeleira, os tremeliques de braço, até certas coreografias pouco ortodoxas de pança e quadris. 
Os próprios músicos, que em geral amam e odeiam seus maestros, lembram que nos ensaios diários a ocorrências dos tais tremeliques chega praticamente a zero. Pra que servem então, são apenas jogo de cena? Outros, por sua vez, reconhecem que durante a performance a música invade o maestro, e seu corpo simplesmente responde ao enfrentamento, para encantamento de todos.

De acordo com Herbert Brün, um saudoso provocador de pensamentos sobre música, a regência ideal seria quase invisível, deixando ao ouvido a possibilidade de se surpreender com as mudanças de intensidade e andamento. Do jeito que os maestros abrem os braços uma fração de segundo antes do evento sonoro, a plateia acaba sendo avisada 'visualmente' do que vai ocorrer na peça. Lamentável, dizia ele.

Quem, todavia, vai conseguir levar o maestro a desistir de ser uma celebridade visual que se emociona com a música?

Mas voltando ao espirro, havia uma boa razão para aqueles tremeliques de bochecha do maestro. Do alto do pódio, podia ver com clareza, assim como o público, que não se tratava apenas de uma simples ocorrência. Junto com o espirro, num mesmo jato, havia pulado uma vistosa dentadura, que agora brilhava vermelha e molhada no solo sagrado da sala de concerto, para desespero de todos - maestro, músicos e público.

Agora que a abertura desviava para tonalidades próximas num esboço de desenvolvimento, mesclando menor e maior com toda a graça mozartiana, a dentadura se oferecia como espetáculo alternativo, ou como releitura pós-moderna, para a curiosidade das primeiras filas, que já cochichavam aqui e ali sobre o desconserto.

Mas quem era o espirrante? Como já dissemos, era um bravo membro do naipe dos segundos violinos, 'Gato', como era carinhosamente chamado pelos amigos Florisvaldo e Vivaldo Conceição. Gato tinha essa mania de espirrar com espalhafato, abrindo braços e 
pernas para aumentar o efeito. Sem pensar, fez isso no meio do concerto, e deu no que deu. $\mathrm{O}$ constrangimento crescia a cada compasso.

Imagine como deve ser difícil para um maestro se concentrar na interpretação de Mozart tendo uma dentadura vermelha e vistosa bem perto do pódio, a desafiar suas escolhas de fraseado. Gato fez de conta que nada havia acontecido, continuou tocando seu violino e parecendo o mais inocente dos mortais.

Como essa estratégia aparentemente não estava dando certo, já que os olhares se intensificaram em sua direção, o violinista mudou de rumo, e lá pelo meio da peça desembainhou o arco e foi esticando-o no chão para ver se conseguia puxar a dentadura de volta, para perto de si.

Depois de algumas tentativas, acompanhadas com espanto por todos, a ponta do arco conseguiu puxar a dentadura escandalosa. Ela foi inicialmente arrastada pelo chão da sala, e quando estava bem perto de sua cadeira, entre acordes e golpes de arco da vizinhança, foi fisgada pela ponta do arco. Rápido como quem rouba, Gato pegou a dentadura com a mão esquerda (o violino ficara no colo) e colocou sem cerimônia em seu lugar de origem.

Foi uma mistura de escândalo e de alívio geral. A situação havia sido resolvida, deixando espaço para que músicos, maestro e ouvintes curtissem adequadamente o que sobrou das Bodas de Figaro. Salvo enganos e 'meras coincidências', tudo isso aconteceu de verdade na Cidade da Bahia, aí por meados do século passado. 


\section{O Brasil merece \\ Não venha, não!}

Tou com pobrema no cadrasto do meu fio...

Não quero que vocês aprendam música como se estivessem numa Europa de cinquenta anos atrás, ou mesmo no tempo de Mário de Andrade, disse aos meus alunos novatos em 2003. Que lugar é esse país? Que estampas sonoras seriam necessárias para cantá-lo adequadamente? Olhem para a rua, procurem as pessoas que moram na rua e perguntem o que elas pensam sobre o Brasil. Existe exercício mais precioso? Tão importante quanto aprender a construir séries dodecafônicas com jeito sertanejo.

A largatixa subiu na tauba seu paulo...

Formiga é um habitante daqui das redondezas. Bebe muito, é vermelho, baixinho, tem cabelo crespo, meio ruivo - daí o apelido. Quando estava apenas meio chapado, perguntei o que ele achava do Brasil. Titubeou um pouco, mas depois iluminou um quase sorriso e respondeu baixinho: “O Brasil merece...”. Depois ainda repetiu umas duas ou três vezes, e na última chegou a dizer: "o Brasil merece, porra!”.

Lá no meu barrio tem.

Ta lá na expressão de Formiga a ideia do coletivo “pátria”. Mas veja que ele usou uma expressão bastante curiosa - o Brasil merece. Afinal, merece o quê? De bom, de ruim? Tive a impressão que ele 
pensava em coisas emocionantes, como futebol e seleção. Mas acabou soltando aquele porra...

Eu sempre vou pra ilha no ferri-boto.

Que espécie de canção deveria ser feita em parceria com Formiga? Como é que democracia e cultura se encontram ou se desencontram na cabeça de quem cria em cultura? Deveríamos convidá-lo para a estreia da peça? Você conhece o arrocha?

Ainda não tirei o rezistro.

Joélio Santos voltava pra casa quando viu alguém mexendo no lixo. Foi se aproximando, e com sua naturalidade natural de Camaçari, perguntou ao habitante da noite: diga aí, meu amigo, o que você pensa do Brasil? O sujeito olhou irritado de volta e só disse uma coisa: "Não venha, não!"

O porteiro me deixou esperando lá no prei.

"Não venha, não" é mais do que um contra-discurso. É uma denúncia da incompatibilidade dos canais. Seria o máximo se todas as pessoas que tivessem que engolir algum discurso goela abaixo no Brasil pudessem simplesmente dizer 'Não venha não'. Hoje em dia esse é o título de um dos 'sucessos' musicais do grupo OCA, formado pelos tais 'novatos' de 2003.

Abrobra.

Mas quanto tempo leva para que uma gestão democrática de cultura produza resultados artísticos realmente interessantes? $\mathrm{Ou}$ vamos ficar chafurdando num populismo estéril? Dá tempo de resistir à pressão dos artistas estabelecidos?

Você não percebe que essa pergunta já é uma rendição prévia à lógica das elites?

Vem os homi qué mi dá baculejo

A periferia pode virar vanguarda? A ancestralidade pode virar vanguarda. Há exemplos consagrados. Cultura em cada um desses campos pode ser coisa bem diferente. 
Focrore.

Uma coisa parece bem clara: ninguém precisa mais daquele artista inspirado da classe média que vai beber na fonte e traduzir o espírito de nosso povo em sua obra imortal.

E sem classe média, o que acontecerá com a identidade brasileira - calcada na base, mas sempre alimentada por cima?

Eu não sou vagabundo, não. Eu tou na rua é porque eu quero... ${ }^{1}$

${ }^{1}$ Frase recolhida por Alex Pochat nas ruas de Salvador, e utilizada em sua Fuga na Série Brasil. 


\section{Quem é o autor?}

Parece uma pessoa, mas quem me garante que assim o seja? Não há em torno de si uma aura de mistério e de ilusionismo? Ele se confunde com a fonte de onde jorram os sentidos...

Tirem o chapéu de couro de Luis Gonzaga, permanecerá o mesmo?

Imaginem por um momento que não se trata do 'Rei do Baião', e sim de um cantor de fados.

Um cantor de tangos e fados na noite carioca... pois foi assim que ele viveu os anos 39 e 40 no Rio.

E só se aproximou da identidade autoral que tomamos por absolutamente legítima hoje, a partir de um peteleco incentivador de Ari Barroso na Rádio Nacional, cantando o chamego 'Vira e mexe'.

Como confiar em autenticidades? Quem foi o autor da autenticidade?

Então há um dedo de Ari Barroso em nosso Luis. E há um dedo de Getúlio Vargas na decisão de Ari Barroso de encorajar personalidades regionais brasileiras. E por aí vai... Há um dedo de todos nós que acolhemos e certificamos autenticidade ao Rei do Baião... Somos seus autores.

Vargas inventou Luis? Não, dizer isso seria exagero e perjúrio.

Quem é o autor? Quem são os autores? De qual (ou de quais) texto(s)? 
O autor é um fingidor? Fingindo que é sua a ideia que deveras teve, além das outras? A autoria não deixa de ser uma performance.

Mais do que uma pessoa (menos do que uma pessoa), talvez a autoria seja um lugar, um lugar a ser descoberto e construído, um lugar ficcional. Um lugar que me chama...

Mas aí acontece essa juntura tão fina, tão bem encaixada entre Luis e forró, entre Luis e a alma de tantos que ouvem, entre Luis e Luis...

Quem vai duvidar que Luis sempre foi Luis, que havia no interior da pedra uma estátua pronta, e o autor apenas se despiu das aparas...?

Se a autoria é um lugar, então é um lugar cheio de linhas que remetem a outros tantos lugares, como aqueles galos de Cabral que tecem uma manhã com raios invisíveis...

Um lugar vazio, pois o autor tanto funda o tempo narrativo, como afunda nele e reverbera, como se fosse um-pai-de-lacan perdido e reinventado... um curioso travesti da sua lei.

Basta lembrar da vertiginosa confusão entre o autor defunto e o defunto autor em Machado de Assis, distribuindo piparotes irônicos a leitores desorientados.

$\mathrm{O}$ autor morto: Deus está morto? (Na escola chamam isso de 'eu lírico'. Mas que lirismo trágico, sarcástico ou simplesmente hiper-realista é esse de Machado e Nietzsche?)

Pois saibam que Roberto Carlos começou a carreira artística imitando João Gilberto numa boate carioca... Pense!

Meu Deus - e se desse certo? Imaginem a confusão que seria gerada no plano divino, na ordem do tempo da música brasileira!

E se os fados e tangos de Luis Gonzaga tivessem dado certo? Teríamos um incrível fadista de chapéu de couro e sanfona de oito baixos? Luis respeita Januário, mas... como? 
E se John Cage, o grande compositor da 'chance music', tivesse continuado aluno de Schönberg em busca de controle e de determinação total? E Tom Zé tivesse continuado nos Seminários de Música da UFBA escrevendo partituras?

E se os minuetos de Mozart não tivessem a graça e a elegância que têm? Se Beethoven não tivesse cortejado as representações do heróico, e Brahms não tivesse cortejado aquela melancolia eufórica que anima sua obra?

São encontros marcados ou taras?

Quem é o autor? Você pensa que é você, mas na verdade não é. A propósito, quem inventou a verdade, quem assina esse outdoor? $\mathrm{O}$ autor seria justamente esse encontro com a mentira verdadeira da criação? Um administrador de sentidos?

As decisões vêm de muitos lugares e até Getúlio interfere nelas. Não existiriam decisões específicas, causas específicas, apenas intertextos, inter-autores, inter-causas...

Vivemos num mundo violento com relação à autoria. Um mundo que nos quer com a mesma desfaçatez, autores individualizados e célebres nulidades sedentas, gerando a síndrome dos 15 minutos de visibilidade.

E certamente há nesse jogo de ser e de fingir ser, de não ser e de fingir não ser, uma gozância toda especial...

Contudo, se eu não sou eu, quem é você caro leitor autor eu e você caras pálidas? 


\section{Cultura, doença e bloqueio}

\section{amoroso}

...deparei com a certeza de que cultura é algo vivo e por isso mesmo em constante renovação e transformação, mas também sujeito a enfermidades...

Ernst Widmer (1979)

Chamo meu filho prum canto e pergunto: o que é que você acha que é a maior doença da cultura hoje?

Ele me responde que isso vai cair naquela análise de que tudo está ficando homogeneizado, e as pessoas são incentivadas a gostar de coisas 'low'.

Mas quem é que vai decidir qual o nível adequado entre 'low' e sofisticado? - pergunto a ele.

E acrescento: Pra mim, que sou compositor contemporâneo, e tenho que responder no juízo final a gente como Webern e Ligeti, (ou mandá-los pra China), quase tudo que as pessoas ouvem e gostam seria considerado 'low'. Mas isso seria também uma forma de preconceito. Que fazer?

Ecoa no ouvido o dito de Mário de Andrade: nada pior que um preconceito, nada melhor que um preconceito; depende da eficácia do preconceito. Fecha parêntesis.

O bom seria que todo mundo gostasse de tudo, diz ele.

Todo mundo gostasse de tudo? Seria possível? 
Aí já seria demais, né? Pelo menos que as pessoas pudessem vir a gostar de outras coisas.

Então, a pior doença da cultura é o bloqueio amoroso que prevalece hoje? As pessoas são impedidas de amar outras coisas - e nesse processo acabam congelando suas identidades junto aos objetos de amor do consumo consumido?

Essa doença do bloqueio amoroso melhora quando o coletivo "população" atinge melhores níveis educacionais?

A resposta imediata é sim, melhora. Mas existem mesmo indicadores confráveis de melhores níveis educacionais? Quantas vezes tenho encontrado gente pobre de periferia, com pouca instrução e sendo muito mais gente, e nesse sentido, muito melhor educada do que os seres universitários? Existe índice para medir essa gentitude de nossa gente humilde?

Além disso, há uma relação entre o sistemão geral que vende coisas, e essa doença que a gente tá falando. Mesmo em lugares de alto índice educacional, se os mecanismos de venda de cultura estão implementados, então o bloqueio amoroso deve estar em vigor...

A China deve estar sendo um excelente laboratório para essa questão. Por isso que mandei Webern e Ligeti pra lá. Como é que uma ex-redoma anti-capitalista reage ao destampamento?

Não precisa ir tão longe. A Bahia também, que ficou várias décadas sob a ótica de um mesmo grupo político, agora vive a insegurança criativa de um destampamento.

Mas há por aí uma espécie de sinuca de bico. Se os mecanismos do bloqueio estão ligados aos mecanismos de venda (capitalista), então a teoria e a prática revolucionária do desbloqueio será e serão necessariamente anti-capitalistas?

Para vencer o bloqueio amoroso será necessário derrubar o sistema, ou é possível buscar mecanismos que estão aí? 
O capitalismo pode ser a solução para o capitalismo? Existe o trans-capitalismo?

Ou serão essas questões irrelevantes porque a essência mesmo é o experimento, a tentativa, o processo?

Você está falando em aumentar as possibilidades das pessoas gostarem de outras coisas, em flexibilidade na formação de identidades, na racionalidade distributiva dos dinheiros associados à cultura, com poucos tubarões e muitas piabas, é isso?

$\mathrm{E}$, além disso, estou falando em qualidade cultural. Qualidade do processo e dos resultados... Com visão ética e sentido de utopia... Pôrra, meu! 


\section{Nós e a Galhofa}

Estava trotando por aí e pensando sobre a mulher do Rui, uma que roubaram lá pela década de 60 e até hoje não há notícias. "Ui, ui, ui, roubaram a mulher do Rui”, era rima e solução. Daí para elucubrar sobre uma crítica da razão anárquica ou esculhambativa que nos constitui e alimenta enquanto cultura pré e pós-carnavalesca, foi apenas um pocotó a mais.

Mesmo sabendo que Carnaval é coisa complexa e cheia de lados, a galhofa e a anarquia são suas marcas distintivas. Basta lembrar: Me segura que eu vou dar um troço (a música já vem com o desmaio grátis), Cabeleira do Zezé, Sassassaricando, Saca-Saca-Saca-Saca-Rolha, Índio quer apito, e todo o repertório recente, da baixa do tubo à boquinha da garrafa via xô satanás!...

Mas, afinal de contas, por que celebrar que roubaram a mulher do Rui, e ao mesmo tempo levantar suspeitas sobre si próprio ("você pensa que fui eu"), só para apresentar uma defesa duvidosa ("mas eu digo que não fui...”)? Pasmem: tudo isso numa nota só, com um corinho chinfrim de refrão de gravadora, e sucesso absoluto no Carnaval de 1967 (Messias).

Gregório de Mattos não escreveria a crítica da razão pura (de Kant), e sim que a Bahia tem dois ff - (e o incômodo desse pensamento é que o autor parece ver e profetizar uma relação de necessidade entre os dois...). Carlinhos Brown não escreveria uma polonaise de Chopin, e este dificilmente ficaria à vontade' na frente do Trio. 
Beethoven não rebolaria seus fundilhos germânicos para alegria do compadre Washington, embora seja o ritmo de sua 5a Sinfonia que nutra o 'Segura o Tchan'... Stockhausen (ou mesmo Cage) não construiriam um instrumento enorme, cheio de furos e de tubos entrando nesses furos, e o chamariam de "A Grande Virgem" como fez Smetak, e nem se interessariam por grandes vaginas místicas na Chapada...

Será que é a água, Mané? A água dos trópicos, predispondo a tudo isso? Ou então é estratégia de sobrevivência de um lugar cultural bastante estranho e tenso? Ou vivemos mesmo no prepúcio do paraíso de Américo Vespúcio (que teria escrito ao Papa anunciando a descoberta do Éden)?

Mas olha que querer fazer sentido do nosso impulso anárquico é deveras arriscado. Cerco-me do cuidado de um período bem longe do Carnaval, e da maresia que muitos dos leitores estarão sentindo com relação ao tema, para tocar em tão delicado assunto. Porque já ouço a polêmica sobre se as gaiatices que fabricamos são sintoma de que há algo podre (no reino da Dinamarca, é claro...) ou vitalidade de estilo, originalidade de uma forma de pensar que deve duvidar de tudo, galhofar de tudo.

Se a galhofa é um sumo destilado da relação entre o salão e a rua (um diálogo que estaria no coração de nossos melhores escrevinhadores, de Gregório a João Ubaldo, como lembra Eneida Leal Cunha), ou se a galhofa é o esconderijo de uma passividade oceânica? Se a galhofa confronta a autoridade instituída, ou se a reforça, emasculando protagonistas e espectadores? Se liberta ou aprisiona? O que fazer com a galhofa? Como lidar com ela em termos de política cultural? Como aumentar o PIB através da galhofa? Como trabalhar para uma galhofa mais justa, digo, sociedade?

Será necessário cuidar para que haja limites, ou a galhofa, sintoma que seja, já vem com os limites da repressão que acalenta? Viva 
quem galhofa, pois graças a eles o número de araquiris é muito baixo entre nós. Viva a galhofa e o rebolado! Viva a mulher do Rui! E quem a roubou! E viva Gregório! Mas viva também quem só consegue sorrir amarelo e nem galhofa, nem nada! 


\section{Fevereiro vem aí - sempre... ${ }^{1}$}

Não repare no título e no artigo. É apenas uma alegoria de Joãozinho Trinta. Um devaneio. Um balangandãzinho pendurado neste fevereiro...

Foi mais ou menos assim que aconteceu: o pessoal do Balé do Senegal foi subindo a ladeira do Pelourinho e deparou, lá em cima, com os ritmos afro-brasileiros do Ilê Fun-fun, tocados em sua homenagem - três atabaques e um agogô, e uma polirritmia lascada.

Se não me engano, houve um momento de perplexidade com o que estava sendo ouvido, um momento muito breve de silêncio, diagnosticando o ambiente rítmico inusitado, procurando saber onde se estava pisando. Mas logo depois de uns dois minutos, um deles, mais corajoso, foi indicado para iniciar o diálogo através dos tambores.

$\mathrm{Na}$ verdade ele se atreveu a dialogar com a música que estava sendo apresentada, e as chances de fazer besteira nessa aventura eram enormes. Como responder a uma trama rítmica já tão complexa e autônoma? Como enfiar a colher naquele angu cultural?

Pois o senegalês corajoso encontrou na malha rítmica umas brechas que ninguém podia imaginar e acrescentou uns repiques agudos ao padrão dos atabaques. Foi um momento meio mágico, porque parecia que eram os próprios tambores que estavam conversando e não seus donos. E era uma conversa ancestral, de povos que foram separados pela história e que agora se reuniam novamente. 
Logo, logo, outros dois percussionistas senegaleses entraram na roda, um dançarino ensaiou uns passos e a Orquestra de Berimbaus que estava quieta, só apreciando, também mandou ver. Teve gente chorando de emoção.

$\mathrm{Na}$ verdade, foi tudo muito breve e profundo. Mas quem ouviu com os ouvidos e com o cérebro ficou pensando nas tantas possibilidades de diálogo entre a Bahia e a África, entre a Bahia e o resto do mundo.

Ficou pensando que ao invés de encontro de tradições, o que estava ali era mais da ordem do contemporâneo. Um encontro condigno e um olhar para o futuro.

$\mathrm{O}$ que pode acontecer aos ritmos baianos quando se encontram, se afirmam e se misturam com as práticas rítmicas da África de hoje? O que pode acontecer a toda a malha cultural que foi construída a partir da batida do samba-reggae e da consciência cultural afro-descendente a partir desses diálogos culturais inusitados e profundos? Qual deve ser a lógica cultural dos carnavais da Bahia, a construção de novos ciclos de criatividade ou a multiplicação de camarotes e mamães-sacode? De onde vão surgir as sementes de um novo ciclo cultural carnavalesco, do salão ou da rua, das gravadoras ou dos Curuzus, Garcias e Tororós da vida?

Como é que se deve criar um processo educativo do capital (é, isso mesmo, educar o capital) de forma a sinalizar o grande potencial lucrativo de um Carnaval que se diferencia, que permanece rejuvenescido como atrativo cultural internacional, que não se perde em repetições e massificação? Em suma, que enxerga logo o que Recife e Olinda já enxergaram.

Como é que se potencializa a participação popular no Carnaval, não como figurantes exóticos, coadjuvantes repetidores, ou simples espectadores de riqueza, opulência e famas alheias, e sim como autores legítimos de uma criação cultural coletiva que se renova? 
Será que para longe do simples sacolejo de egos o Carnaval pode ser uma importante ferramenta de afirmação e de libertação cultural nesses tempos de dominação globalizada?

${ }^{1}$ Pensando em futuros carnavais. Escrito para o Carnaval da Bahia de 2005. 


\section{Música e Oxitocina}

Essa crônica começa com uma ovelha parindo. Segundo consta, logo após o nascimento do filhote, o bulbo olfativo da mãe (localizado em seu cérebro) é banhado intensamente pelo hormônio oxitocina. Com isso, o cheiro do bebê-ovelha será marcado de forma especial em seu cérebro, garantindo a preferência do aleitamento para o recém-nascido.

A oxitocina tem inúmeros papéis e funções, que vão desde o estímulo às contrações do parto, até o fluxo de leite para os recém-nascidos. Todavia, o papel fixador de uma certa percepção-memória foi o que levou um pessoal de neurofisiologia a afirmar que tal seria o caminho das pedras para entender a vinculação emocional entre os humanos e suas músicas, especialmente no que se refere à intensificação do laço social propiciado por experiências musicais comuns.

Pesquisas conduzidas nessa direção revelam uma atuação importante da oxitocina em 'apagar' memórias anteriores e simultaneamente facilitar o processamento/arquivamento de novas memórias, sendo, dessa forma, o cimento entre os eventos significativos e suas lembranças. Mas isso acontece com eficácia muito maior em momentos de clímax ou de êxtase. Tem inclusive um caso famoso...

Certa vez, Pavlov havia treinado vários cães com aqueles choques e recompensas que todos conhecem - e que são a base do behaviorismo e do capitalismo moderno -, mas, um dia, houve uma inundação no laboratório. Pasmem: os cães esqueceram tudo. A cul- 
pa foi da oxitocina que apagou as memórias por causa da situação de pânico.

A conclusão interessante é que o mesmo acontece para o outro lado, na direção da experiência gratificante ao extremo. Se um casal de amantes se liga numa determinada música, vai estar facilitando a subida do hormônio e a fixação emotiva especial de cada um na memória do outro. $\mathrm{O}$ mesmo vale para a comunidade religiosa cantante, ou para o grupo que vai à guerra. A oxitocina muda tudo - para melhor ou para pior.

Aquilo que sentimos quando toca o Hino Nacional na final de uma Copa do Mundo - e que os argentinos nem tchum - só pode então ser o resultado da oxitocina, como hormônio da vinculação social, da celebração do pertencimento.

Para Herbert Brün, renomado professor de criação musical, o importante é compor músicas das quais ainda não se gosta; se o compositor cria coisas das quais já gosta, ou se o ouvinte apenas ouve aquilo que prefere, perde a oportunidade de vir a gostar de algo, sendo esse o processo realmente relevante de transformação cultural que a arte e a sociedade merecem.

Essa forma de pensar reconhece o domínio da emoção em música como o verdadeiro lugar do embate entre a construção de cultura ou de barbárie. Agora basta imaginar o que vai acontecer quando a pesquisa avançar um pouco mais sobre os efeitos da oxitocina (e correlatos) no processo de audição musical. Em princípio, será possível esquentar músicas consideradas absolutamente estranhas ou inóspitas, transformando-as em objeto de reverência estética e de pertencimento.

Isso que a indústria cultural já faz, mas com alto custo de engessamento do sistema - jabá, repetição incessante, promoção exaustiva de ídolos e ídolas, rejeição de valores jovens e distanciamento da qualidade -, poderá ser atingido apenas com a adição do hormônio 
adequado à bebida predileta dos jovens, durante o show, concerto ou programa de televisão - se é que já não estão fazendo isso!

Através da força da neuromusicologia aplicada será também possível reverter preferências musicais. Fãs de rock seriam rapidamente convertidos ao pagode (depois de uma seção estimulada por oxitocina), chorinho e jovem guarda, bossa nova e rap - tudo vai depender do que for mais lucrativo para a indústria de produtos farmacêuticos (a grande responsável pela política musical do futuro).

Obviamente, a cultura letrada também poderá se aproveitar da descoberta, exigindo ciclos de vinculação aos mais diversos repertórios musicais... Não haverá mais seminário de pós-graduação em música sem o apoio da oxitocina.

Quem viver verá, ou ouvirá, ou ficará surdo.

Entrei por uma porta e saí pela outra...

Fonte: "Is music and evolutionary adaptation?" by David Huron, In: The Cognitive Neuroscience of Music (Oxford Press, 2004) 


\section{O que sinto pela música}

Quem saberia dizer realmente o que sente ao ouvir música? As pessoas em geral não sabem falar com qualquer precisão sobre esse assunto. É algo do tipo comichão na barriga? Reboliço no corpo? É descarga de líquido invisível que dá uma sensação de capacidade de pular e de voar?

É uma sensação de estar pairando acima do terreno da vida comum? Uma sensação de ampliação dos poderes humanos? Uma sensação de paz absoluta e meditativa? Uma sensação de que tudo se encaixa?

Afinal, gostar de uma música significa gostar de quê mesmo? Do que se sente, ouvindo-a? E porque a linguagem disponível para tanto é tão rarefeita e imprecisa?

Pergunto a Iracy: qual a música que você mais gosta de ouvir? Roberto, diz ela. E o que você sente quando ouve essa música? Eu choro. E por quê? De alegria. E como é essa alegria? É emoção. E por que você sente essa emoção? Porque eu me lembro de coisas antigas...

Para Fabrício, a música coloca em movimento uma espécie de narrativa, onde ele (ouvinte) é personagem principal, "assim como se fosse uma saga”.

Lembro claramente de quando conheci o Concerto de Brandemburgo n. 3 de Bach, aos doze anos. O que sinto na presença dessa música é de uma intensidade intensa (a linguagem já começa a faltar). Parece que estou descobrindo um mundo que não sabia possí- 
vel, onde doravante gostaria de habitar - é um mundo de euforia e de ritmo.

Já pensou nisso, morar no universo de uma determinada música ou canção? A música coral da África do Sul (que só conheci adulto) tem um poder especial sobre mim. Basta ouvir e já estou emocionadíssimo, sem ter a menor ideia de por quê...?!!! Que é que é isso?

Certa vez ouvia um Trio de Brahms (aquele com clarineta), enquanto minha secretária, a Sra. Neusa, fazia faxina na sala. Instada a comentar o que sentia, e depois de resistir bastante, acabou dizendo: 'parece que essa música está agourando a gente... ' Dois dias depois recebi um comunicado internacional sobre a realização de um simpósio sobre Brahms e a melancolia. Neusa estava certa.

Essa emoção ou des-emoção nos fala de outro viés: a música tendo o poder de 'agourar', de desejar mal, e de praticamente 'fazer mal' a quem a ouve. Obviamente, o lado do 'fazer bem' ocupa a maior parte da cena. As pessoas buscam um bem na música que gostam, mesmo que seja o hormônio oxitocina.

A emoção e a música se encontram e se desencontram ao longo dos séculos. Antes da ciência, quando o mundo era encantado, a música atuava como comprovante dessa ligação entre todos os seres e o cosmos. Há relatos (talvez fantasiosos) de gente desmaiando ao ouvir as primeiras criações polifônicas (várias vozes distintas cantando juntas), lá pelo século $\mathrm{X}$.

A partir do desencantamento do mundo, e com a supremacia da razão instrumental, foi absolutamente necessário inventar a ópera uma espécie de garantia da possibilidade de encantamento pelo som, em cima do palco.

Ao longo dos séculos, a voz permaneceu exercendo o papel desse santuário de adoração do encantamento da música. Mesmo que a ciência e tecnologia dominem tudo, restará a voz e a emoção que desperta... 
A partir do século XVIII, a música instrumental começa a ser objeto de um discurso que a distingue e coloca como 'música pura', música mais elevada que as outras. E é o que ouvimos até hoje em sinfonias e quartetos e celebramos em gênios como Beethoven e Schönberg.

Mas agora, nas últimas décadas, a emoção foi singularizada como objeto preferencial de pesquisa em música. O terreno das emoções é ruim de pesquisa. Foi mais fácil construir a psicanálise do que levar a emoção ao laboratório. E, como sabemos, a construção da psicanálise não torna as coisas mais fáceis para os espíritos quantitativos. A ideia de inconsciente mostra que o quadro da existência humana é deveras complexo. Mesmo assim, ninguém quer desistir de entender e quiçá controlar as emoções - as pílulas e os mercados se multiplicam.

A mesma lentidão vale para o terreno de pesquisa que pretende unir "música e emoção". A pesquisa da cognição musical avançou bastante em áreas como a percepção e mesmo performance. Por exemplo, contamos hoje com modelos bem mais sofisticados para o entendimento dos processos rítmicos. Mas a pesquisa cognitiva quase nunca quer se associar à empreitada da emoção.

Há também um alerta histórico disparado contra o poder alienante da emoção em música. A emoção musical como grande mercadoria dos nossos tempos, como mola propulsora da indústria cultural e, portanto, como território do mal, capitalista, behaviorista, fascista, entre outros. O que diria Adorno?

Mas hoje há maneiras de "enxergar" o cérebro fazendo seu nobre trabalho. Há inclusive uma teoria, segundo a qual a música contaria com redes neuronais próprias, não compartilhadas por outras atividades, tais como a linguagem.

Se tal for o caso, ganha força a hipótese de uma realidade biológica (herdada) para a música - independentemente da inserção 
social e cultural. Cresce o interesse pelo estudo de casos de amusia dificuldades congênitas ou adquiridas com relação à música -, pois eles permitem avançar no entendimento dessa base neurológica de suporte à atividade musical.

Vamos ver no que é que dá. Quais as áreas do cérebro que sentem e como sentem. O que diz a neuromusicologia sobre o assunto? 


\section{Ai, minha mãe!}

1. Vamos proceder por indução. Das melodias de Caymmi, uma das mais atrativas e comoventes é aquela feita em homenagem à Mãe Menininha do Gantois. Basta considerar por um momento a solução composicional encontrada para o gesto principal, aquele que se estabelece como refrão - Ai, Minha Mãe, Minha Mãe Menininha / Ai Minha Mãe, Menininha do Gantois -, tão simples e tão bem trabalhado.

Causa uma certa surpresa descobrir que todo o gesto é, digamos assim, esculpido a partir de um arpejo de acorde perfeito com a quinta no baixo. Na verdade, quase tudo nesse gesto-refrão é construído por arpejos, ora desta sonoridade com a quinta no baixo (uma tônica instável, móvel, insinuando uma dominante 6/4), ora de sua contraparte, a dominante real apresentada em dois formatos, como tríade perfeita, mi-dó\#-lá, e como um arpejo de sétima de Dominante [sol-mi-lá; o dó\# implícito na melodia]. O fato é que todo o refrão desliza nesses arpejos - T, D, D, T -, construindo uma experiência musical que tanto paira no ouvido como se fosse uma espécie de mandala, como excita a expectativa de uma resolução definitiva, guardada para o final, em ré, quando a palavra 'Gantois' aparece com sua sonoridade totalmente distinta dos - ai, ãe, inha -, que dominam toda a parte inicial.

2. Talvez, mais importante ainda que essas referências estruturais harmônicas, seja considerar a energia melódica utilizada. A dra- 
maticidade da evocação da Mãe Menininha - e da divindade feminina a que remete, Oxum -, pois é disso que se trata, vai construída sobre a dramaticidade do arpejo descendente - Ai, Minha Mãe. É curioso que essa Mãe seja evocada com um salto descendente, melhor dizendo, um salto de um agudo levemente gritado ou gemido - e a interpretação joga um papel decisivo aí - para regióes mais profundas. Essa Mãe grave, meio gutural, alia-se ao seu oposto - o 'Ai' agudo - como marcas dessa maternidade / divindade, ou dessa filiação especial.

Mas a Mãe grave não é propriamente um destino, apenas uma passagem, um momento do gesto inteiro que ascende para atingir a sétima (sol), especificando que não se trata de uma mãe qualquer, e sim da Mãe Menininha. As notas sol e mi, que finalizam a primeira metade do gesto e introduzem o arpejo de Dominante, cumprem uma dupla função: o fechamento da semi-frase anterior e o anúncio da posterior.

3. E já neste ponto, algumas questões podem ser postas. Como delimitaremos com precisão o domínio do som e da letra, da música e do texto? O cenário da análise musical produziu nos últimos dez anos um movimento de crítica à tendência hegemônica formalista, a qual buscou durante a maior parte do século XX fazer retornar às próprias relações sonoras todo movimento heurístico. Essa crítica, responsável pela diversificação de enfoques analíticos em músi$\mathrm{ca}$, concentrou em alguns momentos cruciais toda sua verve sobre a desmistificação da ideia de 'música absoluta', apontando os buracos ideológicos sobre os quais repousa conceito e prática tão estabelecidos. Susan McClary (1993) pode ser tomada como referência dessa direção analítica, ao desemaranhar possíveis códigos afetivo-sociais embutidos como esquemas narrativos, via tonalidade e forma, na $3^{\text {a }}$ Sinfonia de Brahms. 
4. De forma semelhante, podemos lembrar que as sonoridades da canção Mãe Menininha apresentam sintaxe sofisticada e comportam uma certa orientação narrativa ${ }^{1}$. Vamos utilizar um recurso de intertextualidade para ilustrar o ponto em questão. Observem o curioso fenômeno representado no exemplo abaixo. Quem diria que essas duas melodias são quase idênticas!

Ex. 1

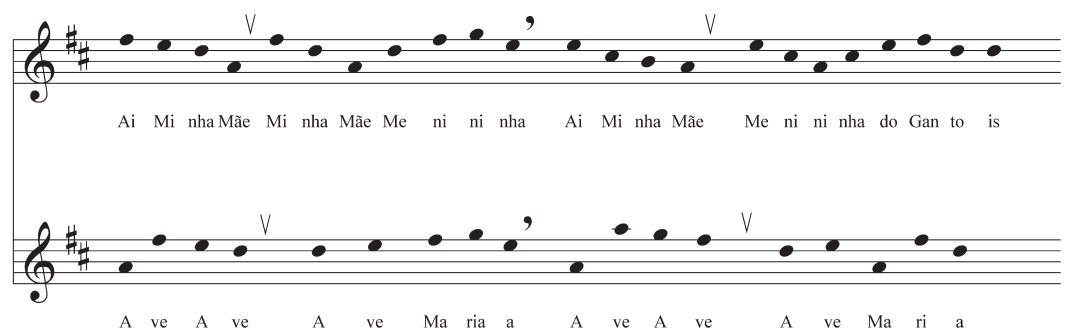

São duas evocações: uma a Oxum, a outra à Virgem Maria. A dramaticidade da evocação à Virgem Maria apoia-se num movimento sempre ascendente, uma ascese, ampliando o intervalo de sexta do motivo inicial até a oitava que as beatas esganiçadamente interpretam em cada procissão. Já com a Mãe Menininha o traçado é ligeiramente diferente, ele oscila, vejam como tem linhas suaves, quase como uma onda serpenteando na praia de nossa audição. Talvez devêssemos lembrar que o título formal da canção é Oração a Mãe Menininha, algo que, de certa forma, envolve diretamente o autor e suas intenções na trama desses significados. 2

5. Estamos, portanto, insinuando que essas ondulações melódicas remetem à própria natureza aquática da entidade evocada. São ondulações suaves, femininas? Embora admitam um certo resvalo que une região aguda e região grave (tomando o âmbito da própria 
melodia como referência), ora apontando para o alto (a estrela mais linda...), ora apontando para um movimento introspectivo, sentido e profundo (o consolo da gente...). Mãe das alturas e mãe do consolo (da perda, da profundeza desse sentir, da morte?). Veja como é importante na melodia o ponto de quebra da onda, ora embaixo, ora no agudo, e o ritmo que essa oscilação cria - Mãe, Menininha, Mãe, Gantois.

6. Sobre o que permite a percepção de equivalência ou similitude entre as duas melodias, podemos dizer que trata-se de uma janela conceitual apontando na direção da noção schoenberguiana de Grundgestalt, ou seja, do esforço de apuração do trabalho composicional medido em termos de elaboração e diferenciação motívica. No caso específico estamos lidando com o formato de sexta - fá\#, mi, ré, lá, em Caymmi, e lá, fá\#, mi, ré, na Ave Maria. Mas por que introduzir esse viés analítico na discussão? Primeiro porque ele está claramente presente na metodologia da comparação entre as duas melodias, ${ }^{3}$ entre os dois discursos (para aceitar a metáfora da narratividade). E, em segundo lugar, porque há aí um vetor temático que merece menção especial. É que subjacente à noção de elaboração motívica em Schönberg, está presente a noção de composição como problematização. O próprio conceito de motivo em música apresenta uma interseção interessante com a construção de um problema algo como um 'unrest', para usar as palavras de Schönberg -, a exigir uma resposta adequada, ou seja, a apresentação de soluções para o conflito produzido.

7. Mas qual a problematização em Caymmi? Certamente, a problematização de Caymmi é algo que paradoxalmente vai lidar com suas estratégias composicionais de evitar complicações desnecessárias, evitar 'problemas', suas estratégias de depuração de um estilo absolutamente simples, feito com duas ou três notinhas pra lá e pra cá. O difícil é fazer. Como é que alguém pode produzir coisas 
tão despojadas e tão imprevisíveis? (Não no sentido do susto, mas no sentido da total ausência de mau gosto, de relações forçadas ou percebidas como desgastadas). Não estou cometendo nenhuma heresia ao dizer que as melodias de Caymmi são menos previsíveis que as de Mozart.

8. Podemos exemplificar algumas situações dessa problematização do despojamento. O final da melodia é uma dessas situações. A palavra 'Gantois', cuja trama composicional já foi mencionada anteriormente, é associada ao motivo - fá\#, ré, ré. Por que não - fá\#, mi, ré -, como seria lógico numa situação de fechamento tonal (closure), solução que seria inclusive respaldada pelo motivo inicial? Auditivamente percebemos que a introdução desse mi destruiria completamente a sutileza e a própria natureza do gesto final da melodia, esculhamba tudo, para ser bem sutil. O curioso é que Caymmi, qua compositor, ou se quiserem, o protagonista composicional ${ }^{4}$ da canção, fez essa opção com muita clareza. Se tivesse estudado teoria e solfejo, é bem possível que não soubesse sair dessa enroscada, caindo no lugar comum da fórmula final previsível.

Há mais de uma linha de argumentação para justificar a inteligência dessa escolha (não reflexiva?) de Caymmi. Em primeiro lugar, o papel de destaque exercido pelo bordão lá, que está presente o tempo todo como limite inferior da 'onda' melódica, seja na Tônica, seja na Dominante. Essa ênfase sobre o lá cria uma centricidade diferenciada sobre o ré. Uma centricidade que não admite fechamento excessivo, pois está sempre pronta para deslizar de volta para o bordão. Mesmo no final do verso, hora inescapável de fechamento, o protagonista composicional evita entregar todos os pontos, e omite a vizinhança mi-ré. Daí para percebermos o papel de destaque ocupado por essa última marola no gingado da onda é apenas um passo. $\mathrm{O}$ motivo fá\#-ré é aquela última quebrada de onda, que brinda nossos ouvidos como se fosse aquela espuma branca e friazinha que se recebe 
na cara e no corpo quando já entramos no mar. A metáfora da onda perderia muito sem esse último gesto. Por último, percebemos todo um jogo de paralelismos - sol-mi, fá\#-ré -, e ainda - mi-dó\#.

Essas duas linhas de argumentação - justificando o detalhe através da conexão com os princípios mais amplos de planejamento de contorno 5 e do paralelismo - apontam para algo que nos parece fundamental como 'problema' composicional da peça.

Ex. 2

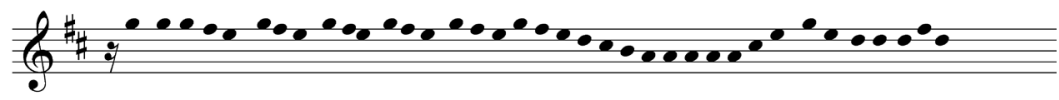

Olorum que mandou essa filha de Oxum / Tomar conta da gente /

E de tudo cuidar / Olorum que mandô-ê-ô / Ora iê-iê-ô

9. Que a segunda parte da melodia apresente uma relação de simetria de contorno com relação à primeira não deve surpreender. Confirma a vigência das ideias composicionais apontadas. Todo o movimento nesta parte ocorre na região aguda, descendo e subindo em seguida, num grande arco (a mando de Olorum), antes das duas marolas finais que evocam as marolas de fechamento das duas semi-frases da primeira parte. $\mathrm{O}$ gesto melódico inicial, alusivo à Mãe, contrasta de forma inegável com este, que permanece nas alturas e desce para enfatizar o vigor de Olorum. Todo o arco acontece sobre o acorde de Dominante com sétima. Por outro lado, o mando de Olorum transforma-se foneticamente em saudação a Oxum: mando-ê-ô / ora-iê-iê-ô. Nesse caso, o paralelismo sol-mi, fá\#-ré, une e separa essas referências a Olorum e a Oxum, da mesma forma como estão relacionadas a primeira e segunda partes da canção. 
10. Temos aí a transição para uma abordagem mais adensada da temática dessa palestra. A dimensão composicional do contorno melódico transita com certa facilidade entre sintaxe e semântica. ${ }^{6} \mathrm{Há}$ de saída a relação profunda entre música e corporealidade, entre o desenho melódico e a sensação que causa. Há a lógica engendrada pelas descidas e subidas da voz. E há, ainda, as referências e os lugares de fala. É possível distinguir pelo menos cinco níveis de referência: o "eu" da voz que canta e proclama uma determinada mãe como sua, um "tu” implícito (que ouve essa oração), o "nós” da identificação produzida em todos aqueles que a ouvem (o "nós" do tomar conta da gente...), a própria Mãe Menininha, Oxum, seu orixá de referência, e Olorum. À intimidade desse eu que ora, que suspira e geme, corresponde o desenho do contorno inicial. A Mãe Meninha é colocada na subida da primeira marola de final de frase. O Gantois (uma primeira referência ao "nós") ocupa a outra marola, aquela que fecha a primeira parte da melodia e se mantém em todos os outros versos com os demais atributos dessa Mãe. Esse gingado ondulatório continua, portanto, através da enumeração desses atributos: a estrela mais linda, o sol mais brilhante, a beleza do mundo, a mão da doçura, o consolo da gente, a Oxum mais bonita. No final desse processo, o sub-refrão 'Tá no Gantois’ assumiu o papel de bordão antifonal. Nesse momento o caminho está preparado para adensar essa caracterização do "nós" (nós do terreiro, nós da Bahia...). É importante observar que isso funciona como transição para a segunda parte, onde cessará, ou mudará de natureza, o movimento de onda tão utilizado até esse ponto. O que toma o seu lugar é aquela marola de terça (sol, fá\#, mi) já comentada anteriormente, que por ser repetitiva e rítmica cumpre muito bem a função de evocação dessa comunidade. O batuque está aí presente como referência, como caracterização daquele que manda. Mas o masculino e o feminino não estão isolados, e sim orques- 
trados, eles se fundem como dimensões de um mesmo fenômeno, dimensões de vida e de ondulação.

11. A essa altura dos acontecimentos, o desafio não é mais a indução, e sim o vislumbre de categorias que possam mapear o campo temático em discussão. Confrontado com esse desafio, a partir da perspectiva da área de composição musical, Herbert Brün (1986) levanta as seguintes dimensões do relacionamento música/linguagem $^{7}$ : a) quando a linguagem é modulada pela música; b) quando a música absorve (imita) comportamentos linguísticos; c) quando música e linguagem se movem em estado de analogia.

Observo de saída que essas dimensões devem ser entendidas como categorias processuais, lembrando com Fernando Cerqueira (1993) que musicalidade e poeticidade podem ser entendidas como resultado de tensões operantes no interior da obra, poética ou musical, e no ato de percebê-la. Além disso, elas não se opõem, é quase como se representassem diferenças de intensidade. Por exemplo, na modulação a interação é menos invasiva que na absorção. $\mathrm{O}$ processo de interação pode chegar até o ponto em que os próprios sons da linguagem são utilizados como material musical. Além disso, há toda uma gama de interação conceitual. Um volume significativo de produção em teoria da música no século XX tem vinculação estreita com a linguística.

12. Pensando em termos da primeira dimensão, vemos que quando a música modula a linguagem o que acontece é uma espécie de deformação construtiva. A palavra Mãe, apresentada no ponto grave do arco, ganha traços semânticos diferenciados. O campo dessas 'modulações' é vastíssimo e não se restringe à música ocidental, é óbvio. Há ainda, na superfície da interação entre poeticidade e musicalidade, o que Cerqueira denominou de anseio e recusa de sentidos, vetores que apontam para a fusão das duas perspectivas e vetores que operam a manutenção da autonomia e das distinções. Vale a pena 
observar que também seria possível afirmar que a linguagem modula a música. A nota lá, atribuída à palavra Mãe, jamais será a mesma. Aliás, a rigor, não existe a nota lá como entidade independente do timbre que a constitui. Descrever a experiência como algo bifásico talvez seja a maior deformação de todas, como querem os fenomenologistas. Nesse sentido, esperar-se-ia o desenvolvimento de ferramentas adequadas à abordagem dessa comunhão. Não é preciso dizer que a música popular é um campo privilegiado para a observação desses processos e aplicação de novas ideias.

13. A segunda categoria processual - quando a música absorve comportamentos linguísticos - é também um vasto território. Podemos movimentar essa paisagem com a menção de todos os construtos desenvolvidos pelo estudo de retórica da música. Há, nos dias de hoje, plena consciência da importância da herança das ideias de Aristóteles, recuperadas na Renascença e utilizadas como lastro de referência para o desenvolvimento de toda a música instrumental do barroco, aflorando na própria teoria da música, notadamente a partir de Matheson no século XVIII, até os dias de hoje. Não há sonata sem exordium, narratio, propositio, confirmatio e peroratio. De acordo com Dahlhaus, era absolutamente radical no século XVIII a afirmativa de que a música era uma linguagem tonal (Tonsprache). Foi, portanto, um longo processo de emancipação, sujeito a inúmeras rabugices, esse da emancipação da música instrumental, merecendo lembrança o dito de Fontenelle (que até Rousseau evoca): 'Sonata, que queres de mim?'.

Em nossa canção de referência, as ondas são também semi-frases, e o paralelismo que exibem pode ser entendido como equivalente às rimas e/ou outros recursos de conexão. A própria dimensão do planejamento do contorno caminha em estreita união com a lógica dos contornos da linguagem (imagine-se um grito/gemido ascendente como o de 'Ai, minha Mãe'; possível, mas improvável). Mais 
uma vez, é preciso lembrar que a linguagem também absorve comportamentos musicais (se os dois processos têm uma raiz comum, fica até difícil prosseguir com esse tipo de raciocínio).

Comento aqui um dos gestos que me parecem dos mais interessantes (talvez devesse fazê-lo adiante). Trata-se do status desse "hein!" que permeia a enunciação dos atributos da Mãe Menininha. Ele é absolutamente desnecessário do ponto de vista do entendimento do texto. Está tudo dito sem ele, e ao mesmo tempo ele muda tudo, ele transforma uma mera enumeração numa conversa cheia de dengo, numa rivalidade fingida sabe-se lá com quem. Como não adere a nenhum conteúdo específico, esse "hein" flutua entre os atributos, sobra e conecta a comunicação. Quando se observa o tratamento que recebe em termos sonoros, o "hein" ocupa o mesmo lugar do "Ai", a nota aguda do arpejo descendente, ora como fá\#, ora como mi, e esse é o caminho de síntese da melodia, a Urlinie schenkeriana, só que o 'hein!" flutuante desafia a chegada em ré, ele permanece soando e criando essa expectativa de permanência.

14. A terceira dimensão talvez seja a mais bela, porque insinua um cenário onde os dois fluxos (música e linguagem) autonomizam-se, permitindo o surgimento de analogias mútuas. Já temos falado bastante desse ponto de vista, basta lembrar que todas essas marolas musicais, essa verdadeira festa de ondas que quebram e salpicam na gente, com arpejos e motivos de terça, caminha em paralelo à alegoria de um povo do qual se percebe a profundidade espiritual, que pratica uma estética do despojamento - por exemplo, através das referências à natureza-cosmos (a estrela mais linda / o sol mais brilhante; novamente Oxum e Olorum; feminino e masculino) -, um povo que celebra o 'estar juntos' e que exalta esse 'estar juntos' como resultado de uma atuação feminina...

Como provocação final, faço questão de lembrar que nem a música, nem a poesia acabam com o final da canção. Quando a sa- 
fra é boa, fica esse desejo incontrolável de falar sobre o assunto e de produzir novos universos analógicos (às vezes compenetrados em ciência), meta-discursos com relação à experiência artística. A rigor, os mesmos desafios continuam presentes, porque o domínio da fala, e da fala analítica, também é um domínio composicional. Ora-iê-iê-ô.

${ }^{1}$ Carlos Reis e Ana Cristina Lopes (1988), no Dicionário de Teoria Narrativa, apresentam como possíveis definições de narração - o processo de enunciação narrativa, e ainda o resultado dessa enunciação. Ainda de acordo com eles, narrativa pode ser entendido enquanto enunciado, ou ainda como conjunto de conteúdos representados por esse enunciado, também como ato de os relatar, ou como modo literário que se opõe ao lírico e ao dramático. Enquanto isso, narratividade ganha o seguinte contorno (colhido do Grupo de Entrevernes): "o fenômeno de sucessão de estados e transformações, inscrito no discurso e responsável pela produção de sentido", e ainda, seguindo Greimas, como “a irrupção do descontínuo na permanência discursiva de uma vida, de uma história, de um indivíduo, de uma cultura”. Mais tarde, Greimas adotará uma acepção muito mais lata, "a narratividade é considerada o princípio organizador de todo o discurso".

${ }^{2}$ Outros exemplos contundentes desse fenômeno de homo-fonia, e com muitas implicações para a análise da música em cultura, seriam os seguintes pares: Hino da Revolução Francesa / Hino Nacional Brasileiro e $5^{\text {a }}$ Sinfonia de Beethoven / Segura o Tchan.

${ }^{3}$ A sub-área de teoria motívica tem produzido um volume considerável de trabalhos apontando incríveis relações de proximidade entre ideias musicais de uma mesma obra (muitas vezes em movimentos distintos) - p.e. em Mozart, Beethoven, Brahms, Schönberg, etc. - que permanecem subjacentes à superfície, dando margem ao desenvolvimento de uma acepção diferenciada do conceito de estrutura musical. 
${ }^{4} \mathrm{O}$ conceito de protagonista representa uma perspectiva sintética de construção poietica da obra, tomando como horizonte os eventos que a constituem, e acenando com a possibilidade de um melhor entendimento da construção de subjetividade em música. Embora coloque em jogo a dimensão narrativa da organização composicional, o ponto de vista do protagonista é distinto do ponto de vista autoral mais abrangente do compositor, justamente pela relação específica com o horizonte dos eventos da obra. Distingue-se ainda do ponto de vista do ouvinte, pelo 'suposto saber' que ostenta a cada instante sobre o que estaria prestes a acontecer, assumindo pelo que de fato acontece, inteira responsabilidade. Sendo assim, a faculdade de saber o que vai acontecer está intrinsecamente ligada à capacidade de fazer acontecer. Nesse sentido, o protagonista é o agente da composição. Como locus ficcional e composicional, como instância de suposto saber, o protagonista cria um nível intermediário entre o autor e seus receptores - um lugar de fala, uma espécie de narrador, caso música fosse discurso - algo que tem a ver simultaneamente com a subjetividade em construção na obra, e com a dimensão coletiva de expectativas dirigidas ao objeto musical. Importa ainda reconhecer que o 'suposto saber', atribuído ao protagonista composicional, também é 'suposto gozar'. O espaço da reflexividade - ou seja, a natureza transicional do objeto-sujeito música - seria o espaço do encontro (fantasia) entre algo que se deseja (e às vezes nem se sabe) e a aparição disso como 'pensamento sonoro'.

${ }^{5} \mathrm{O}$ estudo do contorno, ou de problemas de organização musical a ele relacionados, é uma área de pesquisa em teoria da música com resultados promissores. Basta mencionar o trabalho de Michael Friedman em direção a uma serialização dos contornos (e não das alturas).

${ }^{6}$ Cabe aqui um comentário sobre linhas de pesquisa em análise e teoria da música voltada para o dimensionamento desse antigo fosso. Para Gregory Karl, um analista que trabalha com um modelo analítico derivado do conceito de 'plot' (trama), o objetivo principal é justamente essa integração entre o estrutural e o semântico-expressivo. O conceito de 'plot' é visto como uma espécie de Ursatz da narratividade em música, desmistificando a noção de que estrutura e conteúdo sejam incompatíveis analiticamente. Numa outra direção, surge a ideia de intertextualidade, apoiando-se sobre uma crítica à oposição firmemente estabelecida entre texto e contexto, e pelas metáforas de 'dentro' e 'fora' (da obra, por exemplo), algo que desemboca na tradicional oposição entre história e análise. Não se pode escapar do aprisionamento que a noção de texto autônomo traz em si apelando para o contexto, porque ainda assim você estará confinado ao mesmo esquema binário. Para alguns - p.e. Korsin (1999) - essa é a verdadeira crise da pesquisa em música. Devem ser mencionados ainda o enfoque já tradicional de Lerdahl e Jackendoff, o crescimento recente das pesquisas em semiótica da música - Kofi Agawu, Eero Tarasti -, e a contribuição original de Hans Keller.

${ }^{7}$ Herbert Brün (1986:139) 


\section{O diálogo entre a merda e o marfim}

Vivemos uma contradição engraçada: uma louvação constante da criatividade e de gente criativa - como se música, literatura e cinema aguardassem ansiosos seus novos mestres -, e ao mesmo tempo uma ignorância e descaso colossais com boa parte daquilo que as mentes criativas produzem e produziram ao longo dos séculos e milênios.

O assunto é importante porque quase ninguém fala desse 'excesso' de arte/cultura ao qual estamos expostos. Simplesmente calamos.

$\mathrm{O}$ que a humanidade pretende fazer com esse colossal tesouro simbólico que conseguiu reunir graças aos novos meios tecnológicos, à pesquisa arqueológica, a séculos de preservação de obras originais? Guardá-lo em museus - reais ou imaginários (como o da música)?

Como pretende lidar com o pouco uso que tal tesouro tem despertado, e a aparente entronização de produtos bobageiros e circunstanciais, projetados pela rede midiática mundial em função da necessidade de gerar receitas?

É nesse ponto da crônica que uma impressionante tirada de Gustave Flaubert poderia ser invocada:

Eu sempre quis viver numa torre de marfim, mas uma maré de merda está a bater nas paredes, a fim de derrubá-la. 
Merda e marfim se enfrentam numa batalha titânica nessa imagem de Flaubert, perfeitamente adequada para a crítica da atual degradação cultural pela via globalizada. Será que a visão bobageira vai esterilizar o resto?

Mas esse é apenas um dos ângulos do problema, ou seja: reduzir o foco de visibilidade do imenso tesouro de cultura para apenas alguns produtos vendáveis é sim uma imbecilidade humana, mas segue os passos do pragmatismo capitalista, uma cadeia enorme de causas e consequências, ou melhor, de causas e inconsequências planetárias.

$\mathrm{Na}$ verdade, o excesso de arte sempre existiu. Sempre produzimos muito mais do que nos foi permitido preservar, lembrar e usar. Basta um exemplo: o primeiro compositor de que se tem notícia foi, na verdade, uma compositora - Enheduanna, lá pelos idos de 2.800 a.C., uma sacerdotisa que compunha hinos para o Deus e Deusa da lua, Nanna e Inanna, respectivamente. Quem é que sabe disso?

Até o século XIX, nem tínhamos essa mania da consciência histórica, do impulso de recolher e preservar tudo. Vivíamos comodamente com a perda cíclica - a cada geração - de tudo que era produzido, com raríssimas exceções.

Mas agora que nos tornamos bichos históricos e antropológicos, que assistimos a florestas serem dizimadas, mas gravamos conscienciosamente as canções de seus habitantes perdidos, que estamos prestes a ouvir a música de Enheduanna, o que faremos diante do embate entre merda e marfim? Qual o melhor destino para esse nosso tesouro simbólico excessivo?

Uma solução tão pragmática como o sistema é educar os jovens para a não-criatividade. Há programas formidáveis nessa direção, e os resultados têm sido fantásticos. Que se mande parar as atividades criativas, já! Elas não têm propósito nos dias atuais. Uma sociedade assim educada nem sentiria falta de nada disso. 
Também é possível renomear o criativo, definindo-o como algo bastante inofensivo, que apenas afeta as franjas da realidade. Vale lembrar que uma das mais famosas frases do célebre Gore Vidal é justamente o reconhecimento de que "a merda tem integridade própria”. Não pode ser tão diferente do marfim. Ou seja, também pode ser cultura. Às vezes fraquejo e chego a pensar que Nelson Ned e Elvis Presley não são eruditos.

Mas permanece a questão: o que faremos com aqueles tipos que produzem freneticamente, cada um deles deixando centenas de obras para assombrar o nosso futuro, gente como Machaut, Palestrina, Vivaldi, Bach, Mozart, Schubert e Villa-Lobos? Ou então aqueles outros que produzem algumas poucas obras, porém tão densas que ameaçam atrair toda a atenção erudita para si mesmas. Qual o futuro da erudição? Qual o futuro da complexidade? Deveríamos remodelar o futuro para acomodá-las? 


\section{Algumas Referências}

BRÜN, Herbert. my words and where i want them. London: Princelet, 1986.

CERQUEIRA, Fernando. Musicalidade e Poesia: anseio e recusa de sentido. Salvador: FGM/Quarteto, 2006 (1993).

- Artimanhas do compor e do pensar: percurso criativo através de textos. Salvador: FGM/Quarteto, 2007.

FRIEDMANN, Michael. "A methodology for the discussion of contour: its application to Schoenberg's music". Journal of Music Theory, v. 29, n. 2, p. 223-248, 1985.

HURON, David. Is music and evolutionary adaptation? In: The cognitive neuroscience of music. London: Oxford Press, 2004.

KELLER, Hans. Essays on Music. Christopher Wintle (Org.) Cambridge: Cambridge University Press, 1994.

KORSYN, Kevin. Beyond privileged contexts: intertextuality, influence and dialogue, In: Rethinking Music (Nicholas Cook and Mark Everist Eds.), p. 55-72. London: Oxford University Press, 1999.

LIMA, Jorge de. Poesia Completa. Rio de Janeiro: Nova Aguilar, 1997. LIMA, Paulo Costa. Reflexões sobre o campo do conhecimento composicional. In: VIII Encontro Nacional da ANPPOM, João Pessoa, 1822 ago. 1995. Anais... S.1. [meio eletrônico], p. 13-21, 1996.

. "Bananas ao vento". Revista da Bahia. Salvador, n. 26, maio, p. 40-45, 1998. 
. Ernst Widmer e o ensino de composição musical na Bahia. Salvador: Fazcultura/Copene, 1999.

Entre superfície e estrutura: as estratégias octatônicas de Ernst WIdmer. Tese (Doutorado). Escola de Comunicações e Artes, Universidade de São Paulo, 2000.

. "Composition and Cultural Identity in Bahia", SONUS, Vol. 21, n. 2, p. 61-84, 2001.

McCLARY, Susan. Narrative agendas in 'absolute' music: identity and difference in Brahms's Third Symphony, In: Musicology and difference: gender and sexuality in music scholarship (Ruth Solie Ed.) p. 326-344. Berkeley: University of California Press, 1993.

WIDMER, Ernst. Problemas da difusão cultural. In: Cadernos de Difusão Cultural da UFBA, Salvador, n. 5, 1979.76 p. 

Esta obra foi publicada no formato $160 \times 230 \mathrm{~mm}$ utilizando a fonte Garamond Premiere Pro 11/24pt Impressa no Setor de Reprografia da Edufba Impressão de Capa e Acabamento da Cian Gráfica Papel Alta Alvura $75 \mathrm{~g} / \mathrm{m}^{2}$ para o miolo e Cartão Supremo $300 \mathrm{~g} / \mathrm{m}^{2}$ para a capa. Tiragem de 500 exemplares

Salvador, 2010 